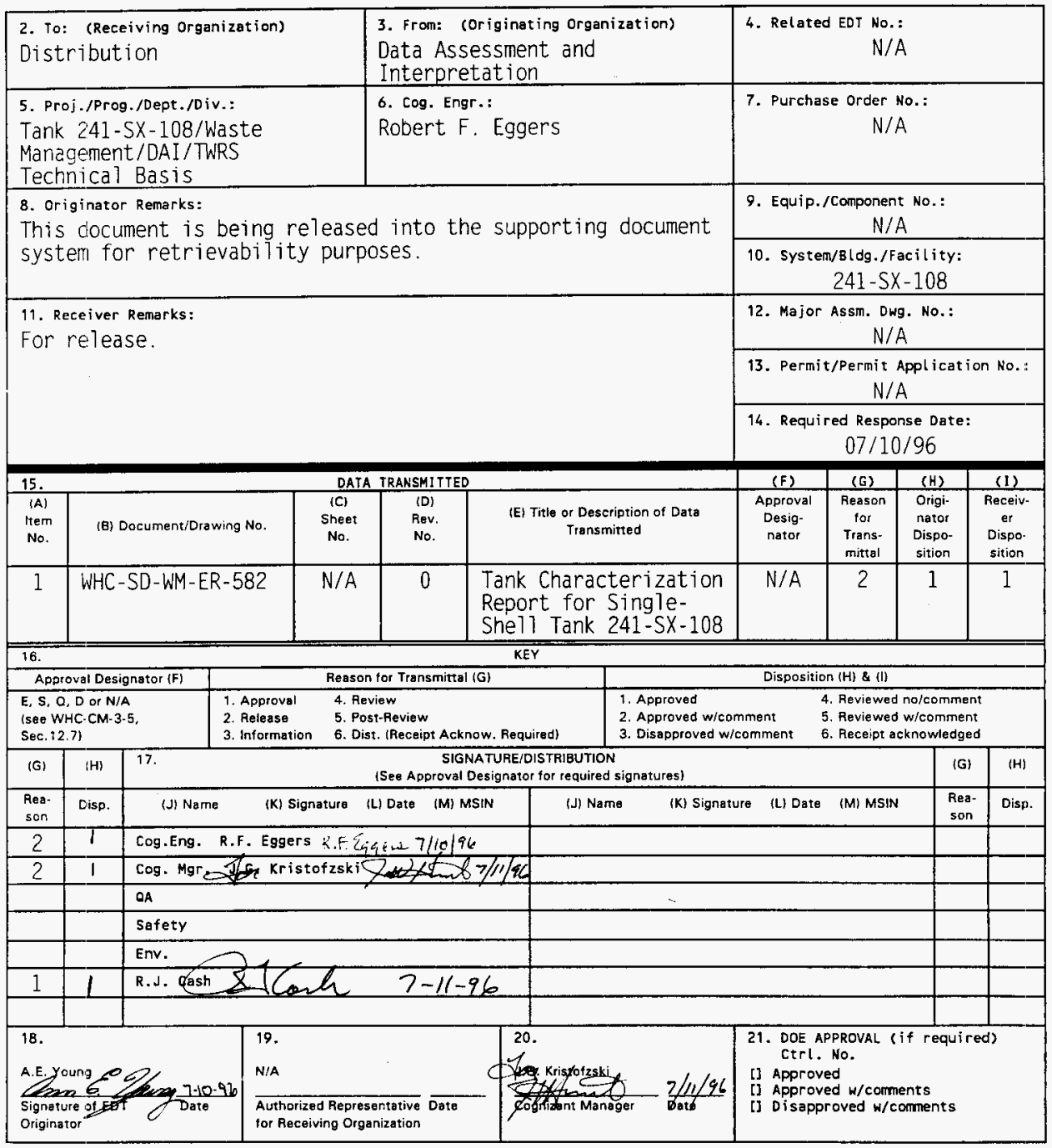

BD-7400-172-2 (04/94) GEF097 


\section{Tank Characterization Report for Single-Shell Tank 241-SX-108}

Robert F. Eggers

Westinghouse Hanford Company, Richland. WA 99352

U.S. Department of Energy Contract DE-AC06-87RL10930

$\begin{array}{lll}\text { EDT/ECN: } & \text { EDT }-616016 & \text { UC: } 2070 \\ \text { Org Code: } & 79400 & \text { Charge Code: N4G4D } \\ \text { B\&R Code: } & \text { EW } 3120074 & \text { Total Pages: //3 }\end{array}$

Key Words: Tank Characterization Report. TCR. Characterization, SingleShe11, SST. Tank 241-SX-108. Tank SX-108, SX-108. SX Farm

Abstract: This document summarizes the information on the historical uses, present status, and the sampling and analysis results of waste stored in Tank 241-SX-108. This report supports the requirements of Tri-Party Agreement Milestone M-44-09.

TRADEMARK DISCLAIMER. Reference herein to any specific commercial product, process, or service by trade name, trademark, manuf Bcturer, or otherwise, does not necessarily constitute or imply its endorsement, recomendation, or favoring by the United States Government or any agency thereof or its contractors or subcontractors.

Printed in the United States of America. To obtain copies of this document, contact: WHC/BCS Document Control Services, P.O. Box 1970, Mailstop H6-08, Richland HA 99352, Phone (509) 372-2420; Fax (509) 376-4989.
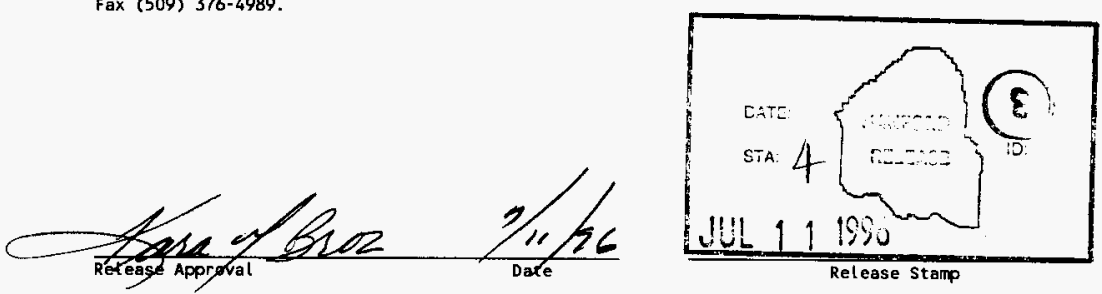

\section{Approved for Public Release}




\section{Tank Characterization Report for Single-Shell Tank 241-SX-108}

R. F. Eggers

Westinghouse Hanford Company

J. D. Franklin

B. J. Morris

T. T. Tran

Los Alamos Technical Associates

Date Published

July 1996

Prepared for the U.S. Department of Energy Assistant Secretary for Environmental Management

$\begin{array}{ll}\text { Westinghouse } & \text { P.O Box } 1970 \\ \text { Hanford Company } & \text { Richland, Washington }\end{array}$

Menegement and Operations Contractor for the

U.S. Depertment of Energy under Contract DE-ACO6-87RL10830

Approved for public release; distribution is unlimited 


\section{EXECUTIVE SUMMARY}

This tank characterization report summarizes information on the historical uses, current status, and sampling and analysis results of waste stored in single-shell underground tank 241-SX-108. This report supports the requirements of the Hanford Federal Facility Agreement and Consent Order Milestone M-44-09 (Ecology et al. 1996).

This report is based on auger samples taken from two risers. The auger devices used to take the samples penetrated about the top $48 \mathrm{~cm}$ (19 in.) of solid waste on the bottom of the tank. The results described below apply only to the top layer of solid waste sampled by augers. Rotary mode core samples of the waste are planned for fiscal year 1998 (Stanton 1996). Based on the analysis of these samples, the following was determined:

- No safety notification limits were exceeded for samples of solid waste

- The vapor above the solid waste did not exceed the notification limit for flammable gas

- The solid waste meets the criteria for reduction-oxidation (REDOX) process high-level waste, except for the 38 to 56 percent moisture content criterion; the waste has dried out since it was transferred into the tank, and contains only about 2 percent moisture.

Tank 241-SX-108 is one of 15 single-shell underground waste storage tanks located in the 200 West Area SX Tank Farm on the Hanford Site. It is the second tank in a three-tank 
cascade series and was one of the first tanks designed for self-boiling waste. Although it is an actively ventilated, high-heat-load tank, it is not on a Watch List. The tank went into service in November 1955, receiving REDOX high-level waste. Because it was a self-boiling tank, tank 241-SX-108 was connected to an exhauster and waste contained in the tank was allowed to self concentrate. This occasionally increased the heat load on the ventilation system, and the condensate from the self-boiling process was directed back to the tank to maintain an even cooling rate. From 1959 to 1963 , frequent transfers were made to tank 241-SX-108 from tanks 241-SX-105, 241-SX-106, and 241-SX-115. These transfers involved condensate from self-boiling actions, as well as REDOX high-level waste generated from 1952 to 1957 (R1) and REDOX high-level waste generated from 1958 to 1966 (R2). In 1967, tank 241-SX-108 was declared an assumed leaker and removed from service. Administrative interim stabilization was completed in August 1979 and intrusion prevention in December 1982.

A description and status of tank 241-SX-108 are given in Table ES-1 and Figure ES-1. The tank has an operating capacity of $3,800 \mathrm{~kL}(1,000 \mathrm{kgal})$ and presently contains an estimated $330 \mathrm{~kL}(87 \mathrm{kgal}$ ) of waste. Hanlon (1996) classifies all of the waste as sludge, but analysis of auger samples from the top $48 \mathrm{~cm}$ (19 in.) indicate that sodium nitrate is a major compound in the waste. It is therefore projected that the waste from the top $48 \mathrm{~cm}$ is a mixture of soluble and insoluble compounds. The likelihood that the waste is a mixture of soluble and insoluble compounds is important to the waste retrieval process. Also, according to Hanlon (1996), the waste contains an estimated $19 \mathrm{~kL}(5 \mathrm{kgal})$ of drainable interstitial liquid. 
Table ES-1. Description and Status of Tank 241-SX-108.

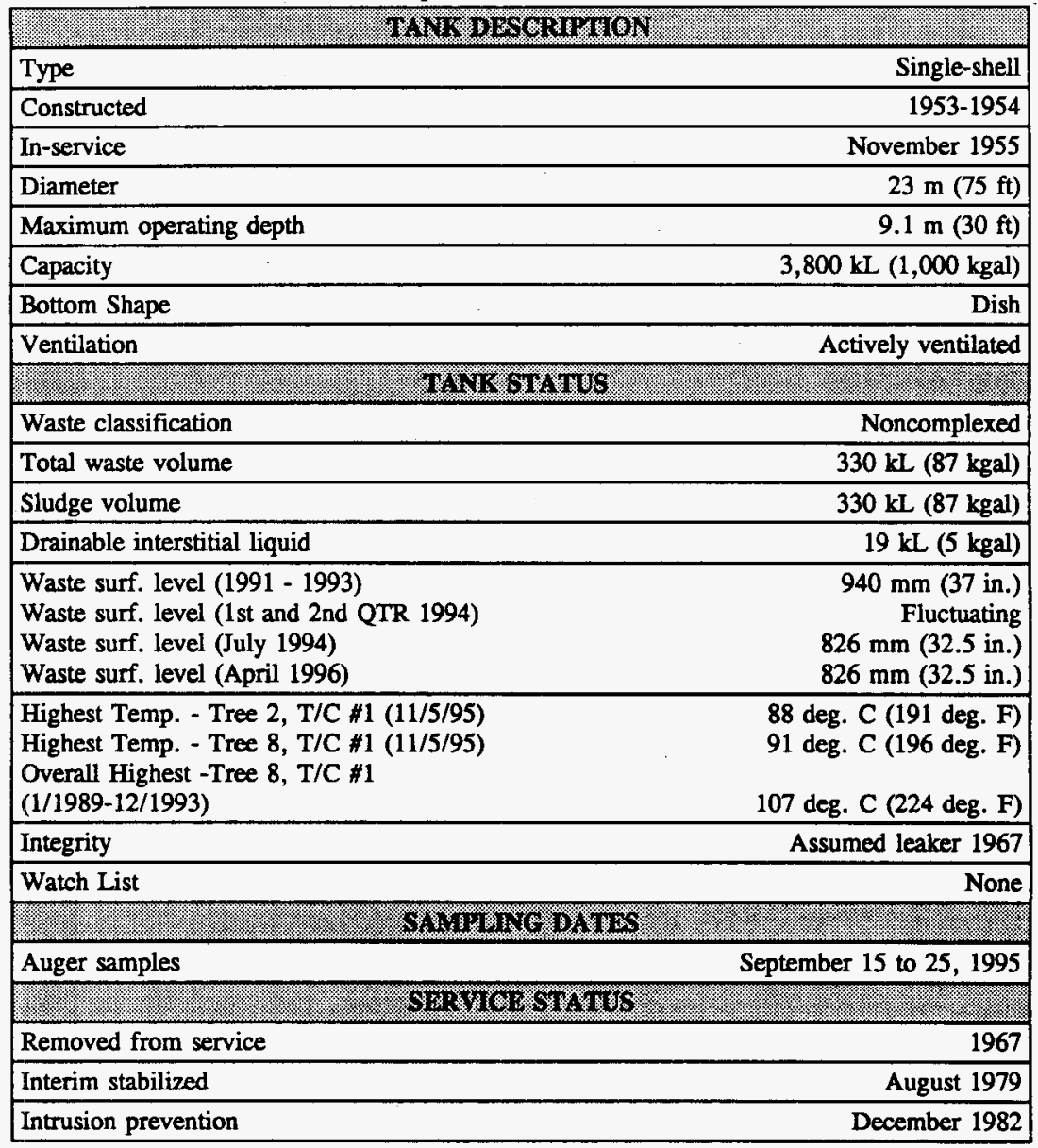


Figure ES-1. Tank 241-SX-108 Riser Locations and Elevation View of Waste.

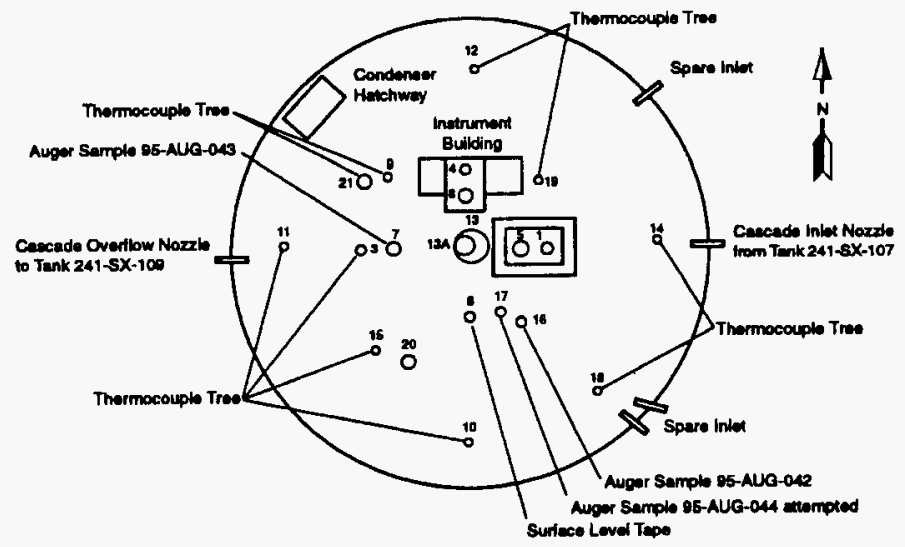

Fiser Locations

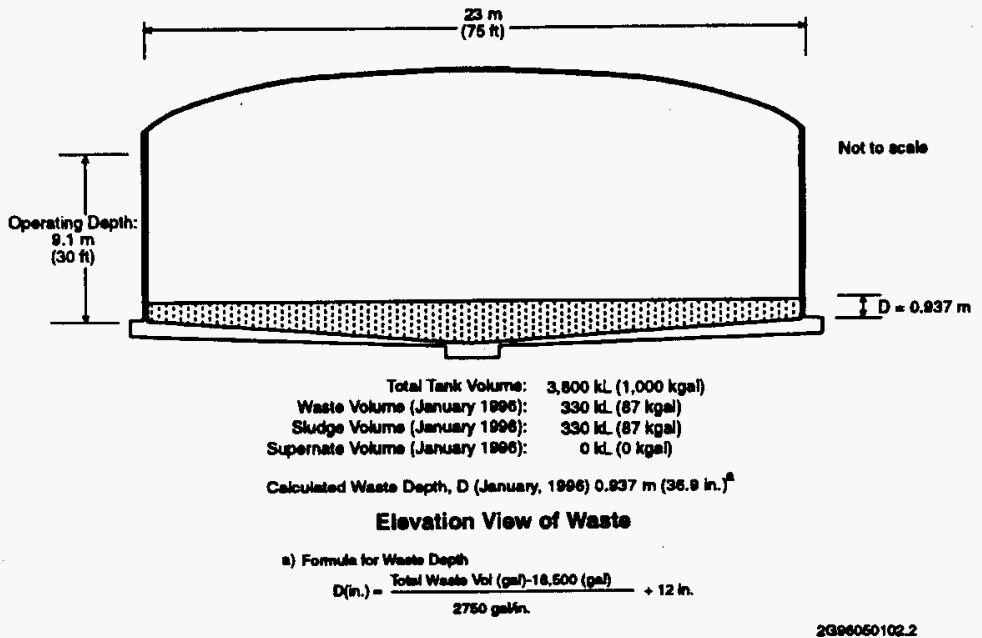


The exact reason(s) for changes in the measured value of the height of the waste, as shown in Table ES-1, are not known. Possible reasons include: 1) changing from the conductivity probe method of detecting the top of the waste to the "slack tape" method; 2) creating a hole in the waste surface by repeated deployment of the probe; 3 ) changes in the waste surface. Because of this uncertainty, waste surface levels and volumes are considered approximate.

Tank SX-108 contains two layers of REDOX high-level waste, which are of interest to the Historical DQO and the Pretreatment DQO. The waste in tank SX-108 generates a lot of heat and consequently has become dry and hard. Solidified REDOX waste poses a substantial technical challenge to waste retrieval, pretreatment, and final treatment activities.

A decision was made to sample tank 241-SX-108 by the auger method in 1995 rather than waiting to sample it by the rotary-mode method. The push-mode method could not be used because the waste is dry and hard. The rotary mode system can probably sample the waste successfully, but has not been available because it has been undergoing modification for use in flammable gas tanks.

The time required to modify the rotary mode system, and the relatively low priority of tank SX-108 for rotary mode sampling, has caused the date for rotary mode sampling to move out to 1998 (Stanton 1996). The auger method of sampling was considered capable of obtaining enough REDOX waste to provide the information needed. 
The information learned from the 1995 auger sampling event will aid in preparing sampling plans for other tanks with the same type of waste and will contribute to the resolution of several outstanding technical questions regarding the composition and properties of REDOX waste.

Acquisition of three auger samples was attempted from risers 7,16 , and 17 , but no sample material was obtained from riser 17 . The samples from risers 7 and 16 were labeled auger samples 95-AUG-042 and 95-AUG-043. Both auger samples were analyzed at the 222-S Laboratory in accordance with the Tank Safety Screening Data Quality Objective (Dukelow et al. 1995), the Strategy for Sampling Hanford Site Tank Wastes for Development of Disposal Technology (Kupfer et al. 1995), and the Historical Model Evaluation Data Requirements (Simpson and McCain 1995). The requirements of the three data quality objectives (DQOs) were integrated by the Tank 241-SX-108 Auger Sampling and Analysis Plan (Eggers 1995a).

The safety screening DQO (Dukelow et al. 1995) requires analyses for fuel content using differential scanning calorimetry (DSC), percent water by thermogravimetric analysis (TGA), total alpha activity through alpha proportional counting, and bulk density. Before samples were removed from the tank, combustible gas meter readings were taken from within the tank headspace as required by the safety screening DQO. 
As part of their new process development work to support disposal activities, the Pacific Northwest National Laboratory is performing sludge washing tests on tank SX-108 samples. Characterization results from these studies will be addressed in a future revised version of this tank characterization report. Analyses required by the historical DQO included bulk density, energetics, and moisture content, in addition to metal concentrations by inductively coupled plasma (ICP), anion concentrations by ion chromatography spectroscopy (IC), total organic carbon (TOC) by persulfate and coulometry, uranium by phosphorescence, and total beta analysis (Eggers 1995a). Bulk density measurements were not carried out, because the sample material was very dry and flighty and because some individual samples produced radiological dose rates exceeding $90 \mathrm{R} / \mathrm{hr}$.

None of the notification limits established by the safety screening DQO were exceeded. None of the DSC scans exhibited exothermic reactions. Total alpha activity results for both augers were well below the safety screening notification limit of $41 \mu \mathrm{Ci} / \mathrm{g}$. The highest result for the auger samples was $5.4 \mu \mathrm{Ci} / \mathrm{g}$, indicating that the potential for a criticality is low. The highest 95 percent upper confidence limit for total alpha activity was $7.35 \mu \mathrm{Ci} / \mathrm{g}$.

An Industrial Health and Safety vapor survey using a combustible gas meter, performed before the tank was sampled, found the flammable vapor concentration to be 0 percent of the lower flammability limit (LFL), satisfying the DQO requirement of less than 25 percent of the LFL. Because auger sampling the top $48 \mathrm{~cm}$ (19 in.) of waste does not provide a complete profile of the solid waste, safety screening for this tank will not be complete until at least two cores of the waste to the bottom of the tank have been obtained and analyzed 
(Eggers 1996). According to Stanton (1996), tank SX-108 is scheduled to be rotary mode core sampled during 1998.

The requirements of the pretreatment DQO were met by providing samples of tank 241-SX-108 waste to the Pacific Northwest National Laboratory (PNNL) for analysis. Material from both auger samples was set aside for pretreatment studies as identified in the pretreatment DQO (Kupfer et al. 1995). One sample was provided from the lower half of sample 95-AUG-042 and one from the upper half of sample 95-AUG-043.

An historical evaluation was performed on both auger samples as prescribed in the historical DQO (Simpson and McCain 1995). The fingerprint analytes were sodium, aluminum, chromium, cesium-137, strontium-90, and water. Comparisons were made between the analytical results and the DQO-defined reference levels for these analytes. Except for percent water, results for all fingerprint analytes met the criteria for passing the fingerprint test. The measured value of moisture content is about 2 percent. To pass the fingerprint test, the measured value of analyte concentration in the waste must be at least 10 percent of the reference value specified in the historical DQO. Once the fingerprint test has been passed, further analyses (secondary analyses) must be performed. One of these analyses is TOC (total organic carbon). The established notification limit for TOC is $30,000 \mu \mathrm{g} \mathrm{C} / \mathrm{g}$. Results ranged from 90.7 to $1,680 \mu \mathrm{g} \mathrm{C/g}$ (average of sample and duplicate values) with a mean of $900 \mu \mathrm{g} \mathrm{C} / \mathrm{g}$. 
Because only the top $48 \mathrm{~cm}$ (19 in.) of waste were sampled, a tank heat load based on the 1995 analytical data could not be calculated. An estimate of $7.48 \mathrm{~kW}(25,500 \mathrm{Btu} / \mathrm{hr})$ was available from the historical tank content estimate (HTCE) (Brevick et al. 1994a). The value estimated from the headspace temperature is $16.4 \mathrm{~kW}(56,000 \mathrm{Btu} / \mathrm{hr})$ (Kummerer 1994). Surveillance data show tank temperatures ranging from about $47^{\circ} \mathrm{C}\left(117^{\circ} \mathrm{F}\right)$ to $107^{\circ} \mathrm{C}$ $\left(224^{\circ} \mathrm{F}\right)$, during the period January 1989 to the present.

The waste surface level has remained about the same ( $826 \mathrm{~mm}$ [32.5 in.]) from July 1994 to the present. The most recent manual tape reading was $826 \mathrm{~mm}$ (32.5 in.) on April 2, 1996.

Table ES-2 provides concentrations for the most prevalent analytes and analytes of concern based on the 1995 analytical results. 
WHC-SD-WM-ER-582, Rev. 0

Table ES-2. Major Analytes and Analytes of Concern in Waste.

\begin{tabular}{|c|c|c|}
\hline (1) & Mega Value & $\begin{array}{l}\text { Relithe Standard } \\
\text { Derlation }(\%)\end{array}$ \\
\hline Aluminum & 38,100 & 37.4 \\
\hline Calcium & 1,750 & 50.2 \\
\hline Chromium & 9,070 & 13.7 \\
\hline Iron & 17,900 & 42.13 \\
\hline Manganese & 5,990 & 49.3 \\
\hline Nickel & 1,190 & 46.4 \\
\hline Silicon & 1,090 & 49.1 \\
\hline Sodium & $1.85 \mathrm{E}+05$ & 17.2 \\
\hline Sulfur & 1,960 & 40.5 \\
\hline Uranium & 7,540 & 56.5 \\
\hline M Milns & (2) & (1) 4 \\
\hline Chloride & 2,160 & 23.9 \\
\hline Nitrate & $3.72 \mathrm{E}+05$ & $\overline{553.4}$ \\
\hline Nitrite & 15,700 & 30.0 \\
\hline Oxalate & 3,130 & 42.0 \\
\hline Sulfate & 6,890 & 14.9 \\
\hline 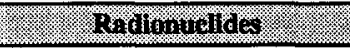 & (1) $W_{0}$ & 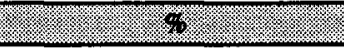 \\
\hline Total Alpha & 3.29 & 45.6 \\
\hline Total Beta & 6,930 & 52.1 \\
\hline${ }^{8990} \mathrm{Sr}$ & 3,070 & 52.3 \\
\hline
\end{tabular}




\section{CONTENTS}

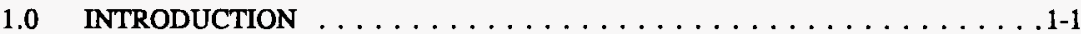

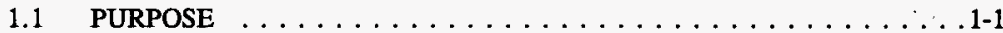

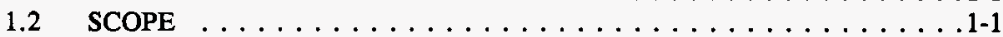

2.0 HISTORICAL TANK INFORMATION $\ldots \ldots \ldots \ldots \ldots \ldots \ldots \ldots \ldots$

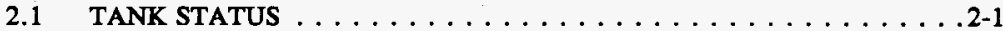

2.2 TANK DESIGN AND BACKGROUND $\ldots \ldots \ldots \ldots \ldots \ldots \ldots 2-2$

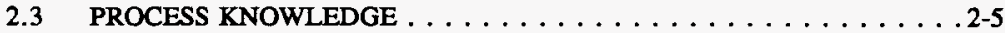

2.3.1 Waste Transfer History . . . . . . . . . . . . . 2-5

2.3.2 Historical Estimation of Tank Contents . . . . . . . 2-6

2.4 SURVEILLANCE DATA $\ldots \ldots \ldots \ldots \ldots \ldots \ldots \ldots \ldots \ldots$

2.4.1 Surface Level Readings . . . . . . . . . . . . . 2-10

2.4.2 Internal Tank Temperatures . . . . . . . . . . . 2-10

2.4.3 Drywells . . . . . . . . . . . . . . 2-11

2.4.4 Tank 241-SX-108 Photograph . . . . . . . . . . . 2-14

3.0 TANK SAMPLING OVERVIEW $\ldots \ldots \ldots \ldots \ldots \ldots \ldots \ldots \ldots \ldots . \ldots \ldots$

3.1 DESCRIPTION OF SAMPLING EVENT $\ldots \ldots \ldots \ldots \ldots \ldots$ 3-1

3.2 SAMPLE HANDLING $\ldots \ldots \ldots \ldots \ldots \ldots \ldots \ldots \ldots \ldots \ldots \ldots$

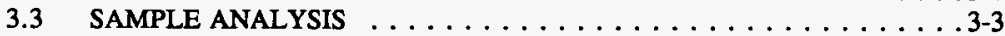

4.0 ANALYTICAL RESULTS $\ldots \ldots \ldots \ldots \ldots \ldots \ldots \ldots \ldots \ldots .1$

4.1 OVERVIEW . . . . . . . . . . . . . . .

4.2 DATA PRESENTATION $\ldots \ldots \ldots \ldots \ldots \ldots \ldots \ldots \ldots \ldots$ 4-2

4.2.1 Data Summary . . . . . . . . . . . . . 4-2

4.2 .2 Physical Data Summary $\ldots \ldots \ldots \ldots \ldots \ldots \ldots \ldots .4 .4 \ldots \ldots \ldots$

4.2 .3 Vapor Data Summary $\ldots \ldots \ldots \ldots \ldots \ldots \ldots \ldots \ldots \ldots$

5.0 INTERPRETATION OF CHARACTERIZATION RESULTS $\ldots \ldots \ldots \ldots .5$ 5-1

5.1 ASSESSMENT OF SAMPLING AND ANALYTICAL RESULTS . . . . 5-1

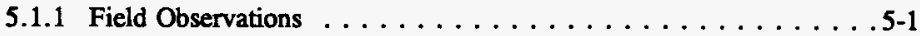

5.1 .2 QC Assessment . . . . . . . . . . . . . . 5-1

5.1.3 Data Consistency Checks . . . . . . . . . . . . . . . 5-2

5.2 COMPARISON OF HISTORICAL WITH ANALYTICAL RESULTS . . . 5-5

5.3 TANK WASTE PROFILE . . . . . . . . . . . . . 5-5

5.4 COMPARISON OF TRANSFER HISTORY WITH ANALYTICAL RESULTS . . . . . . . . . . . . . . . . . . . . 5-5

5.5 EVALUATION OF PROGRAM REQUIREMENTS $\ldots \ldots \ldots \ldots \ldots \ldots$ 5-7

5.5.1 Safety Evaluation . . . . . . . . . . . . . . . . 5-7

5.5.2 Pretreatment Evaluation . . . . . . . . . . . . 5-8

5.5 .3 Historical Evaluation $\ldots \ldots \ldots \ldots \ldots \ldots \ldots \ldots . . \ldots \ldots$ 
WHC-SD-WM-ER-582, Rev. 0

\section{CONTENTS (Continued)}

6.0 CONCLUSIONS AND RECOMMENDATIONS $\ldots \ldots \ldots \ldots \ldots$ 6-1

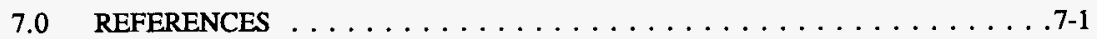

APPENDIX A

ANALYTICAL RESULTS - SINGLE-SHELL TANK 241-SX-108 $\ldots \ldots \ldots$ A-1 


\section{LIST OF FIGURES}

2-1. Riser Configuration for Tank $241-$ SX-108 $\ldots \ldots \ldots \ldots \ldots \ldots$ 2-4

2-2. Tank 241-SX-108 Configuration . . . . . . . . . . . . . 2-5

2-3. Tank Layer Model for Tank 241-SX-108 . . . . . . . . . . . . 2-7

2-4. Tank 241-SX-108 Level History . . . . . . . . . . . . . 2-12

2-5. Tank 241-SX-108 Weekly High Temperature Plot $\ldots \ldots \ldots \ldots$. . . . . 2-13

\section{LIST OF TABLES}

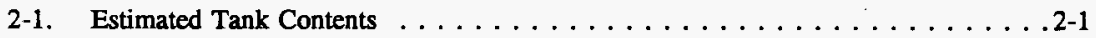

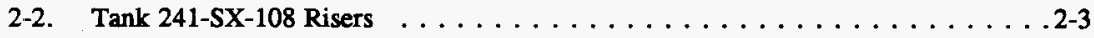

2-3. Summary of Tank 241-SX-108 Waste Transfer History . . . . . . . . . . 2-6

2-5. Tank 241-SX-108 Inventory Estimate

Based on Historical Tank Content Estimate $\ldots \ldots \ldots \ldots \ldots \ldots \ldots . . \ldots 2$

3-1. Tank 241-SX-108 Sample Recovery and Description $\ldots \ldots \ldots \ldots \ldots$ 3-2

3-2. Tank 241-SX-108 Subsampling Scheme $\ldots \ldots \ldots \ldots \ldots \ldots \ldots . \ldots .2$

3-3. Summary of Samples and Analyses $\ldots \ldots \ldots \ldots \ldots \ldots \ldots \ldots \ldots$

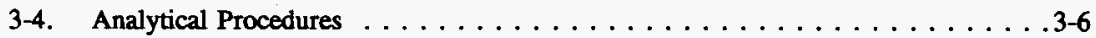

4-1. Analytical Data Presentation Tables $\ldots \ldots \ldots \ldots \ldots \ldots \ldots \ldots \ldots$ 4-1

4-2. Chemical Data Summary for Tank $241-S x-108 \ldots \ldots \ldots \ldots$. . . . . . . . 
WHC-SD-WM-ER-582, Rev. 0

\section{LIST OF TABLES (Continued)}

4-3. Thermogravimetric Analysis Results for Tank 241-SX-108 . . . . . . . . 4-5

4-4. Differential Scanning Calorimetry Results for Tank 241-SX-108 . . . . . . . 4-6

5-1. Tank 241-SX-108 Comparison of Gross Beta Activities With the Total of the

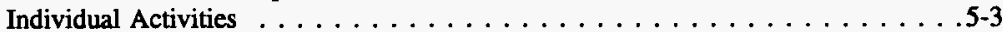

5-2. Comparison of Historical Estimates with the 1995 Analytical Results for Tank 241-SX-108 . . . . . . . . . . . . . . . . . . .5-5

5-3. Safety Screening Data Quality Objective Decision Variables and Criteria . . . . 5 5-7

5-4. Comparison of Fingerprint Analytes with Analytical Results . . . . . . . . 5-8 


\section{LIST OF TERMS}

\begin{tabular}{ll} 
ANOVA & analysis of variance \\
Btu/hr & British thermal unit per hour \\
Ci & curies \\
cm & centimeter \\
c/s & counts per second \\
DQO & data quality objective \\
DSC & differential scanning calorimetry \\
ft & feet \\
gal & gallons \\
g & grams \\
g/L & grams per liter \\
g/mL & grams per milliliter \\
GEA & gamma energy analysis \\
HDW & Hanford Defined Waste \\
HTCE & Historical Tank Content Estimate \\
in & inch \\
IC & ion chromatography \\
ICP & inductively coupled plasma spectroscopy \\
J/g & joules per gram \\
kg & kilograms \\
kgal & kilogallons \\
kL & kiloliters \\
kW & kilowatts \\
LFL & lower flammability limit \\
m & meter \\
M & moles per liter \\
mm & millimeter \\
mR/hr & milliroentgen per hour \\
ppm & parts per million \\
PNNL & Pacific Northwest National Laboratory \\
QC & quality control \\
R1 & REDOX high-level waste generated from 1952 to 1957 \\
R2 & REDOX high-level waste generated from 1958 to 1966 \\
REDOX & reduction-oxidation \\
R/hr & roentgens per hour \\
RSD & relative standard deviation \\
SAP & sampling and analysis plan \\
TLM & Tank Layer Model \\
TGA & thermogravimetric analysis \\
TOC & total organic carbon \\
W & watts \\
& \\
\hline &
\end{tabular}


WHC-SD-WM-ER-582, Rev, 0

\section{LIST OF TERMS (Continued)}

$\begin{array}{ll}\text { WHC } & \text { Westinghouse Hanford Company } \\ \text { WSTRS } & \text { Waste Status and Transaction Record Summary } \\ \text { weight percent } \\ \text { wt } \% \\ { }^{\circ} \mathrm{C} & \text { degrees Celsius } \\ { }^{\circ} \mathrm{F} & \text { degrees Fahrenheit } \\ \mu \mathrm{g} \mathrm{C} / \mathrm{g} & \text { micrograms carbon per gram } \\ \mu \mathrm{Ci} / \mathrm{g} & \text { microcuries per gram } \\ \mu \mathrm{eq} / \mathrm{g} & \text { microequivalents per gram } \\ \mu \mathrm{g} / \mathrm{g} & \text { micrograms per gram }\end{array}$




\subsection{INTRODUCTION}

This tank characterization report summarizes the information on the historical uses, current status, and sampling and analysis results of waste stored in single-shell tank 241-SX-108. The tank was sampled in 1995 to satisfy the requirements of: Tank Safery Screening Data Quality Objective (Dukelow et al. 1995), the Historical Model Evaluation Data Requirements (Simpson and McCain 1995), and the Strategy for Sampling Hanford Site Tank Wastes for Development of Disposal Technology (Kupfer et al. 1995). This report supports the requirements of the Hanford Federal Facility Agreement and Consent Order Milestone M-44-09 (Ecology et al. 1996).

Tank 241-SX-108 was removed from service in 1967 and interim stabilized in 1979. Consequently, the composition of the waste should not change appreciably until pretreatment and retrieval activities commence. The waste analyte concentration measurements reported in this document reflect the current composition of the waste based on available data. Tank 241-SX-108 is not on any Watch Lists.

\subsection{PURPOSE}

This report summarizes information concerning the use and contents of tank 241-SX-108. When possible, this information will be used to assess issues associated with safety, operations, environmental, and process activities. This report also serves as a reference point for more detailed information about tank 241-SX-108.

\subsection{SCOPE}

Auger samples were taken in September of 1995. Prior to retrieving these samples, tank headspace vapors were measured using a combustible gas meter to determine the lower flammability limit of the vapors. Auger samples 95-AUG-042 and 95-AUG-043 were analyzed to comply with the requirements of the safety screening, pretreatment, and historical DQOs. Because sampling the top of the waste does not provide a complete profile of all of the solid waste in the tank, the safety screening analyses for this tank will not be complete until cores to the bottom of the tank from at least two risers have been obtained and analyzed. However, subsampling and analyses performed on the auger samples did meet the requirements of the pretreatment and historical DQOs. 
WHC-SD-WM-ER-582, Rev. 0

This page intentionally left blank. 


\subsection{HISTORICAL TANK INFORMATION}

This section describes tank 241-SX-108 based on current and historical information. The first part details the current condition of the tank. The next part discusses the tank's background, transfer history, and the process sources that contributed to the tank waste, including an estimate of the current contents based on the process history. Conditions that may be related to tank safety, such as potentially hazardous tank contents or off-normal operating temperatures, are included. The final part summarizes available surveillance data for the tank. Solid and liquid level data are used to determine tank integrity (leaks) and to provide clues to internal activity in the solid layers of the tank. Temperature data are provided to evaluate the heat-generating characteristics of the waste.

\subsection{TANK STATUS}

As of January 31, 1996, tank 241-SX-108 contained an estimated $330 \mathrm{~kL}$ (87 kgal) of noncomplexed waste (Hanlon 1996). Liquid volume was determined using a photographic evaluation method, and solids volume was determined using a manual tape surface level gauge. The last solids volume estimate reported in Hanlon (1996) was performed in December 1993. The volume of the various waste phases found in the tank are shown in Table 2-1.

Table 2-1. Estimated Tank Contents. ${ }^{1}$

\begin{tabular}{|c|c|c|}
\hline \multirow{2}{*}{ Whaste fromos } & \multicolumn{2}{|c|}{ 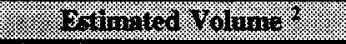 } \\
\hline & 134 & $14 \mathrm{~B}^{3}$ \\
\hline Total waste & 330 & 87 \\
\hline Supernatant liquid & 0 & 0 \\
\hline Drainable interstitial liquid & 19 & 5 \\
\hline Drainable liquid remaining & 19 & 5 \\
\hline Pumpable liquid remaining & 0 & 0 \\
\hline Sludge & 330 & 87 \\
\hline Saltcake & 0 & 0 \\
\hline
\end{tabular}

Notes:

'Hanlon (1996)

${ }^{2}$ For definitions and calculation methods refer to (Hanlon 1996) Appendix C.

In 1962, tank 241-SX-108 was suspected of being a leaker and in 1967 was declared an assumed leaker (with a leak volume between $9 \mathrm{~kL}(2.4 \mathrm{kgal})$ and $132 \mathrm{~kL}(35 \mathrm{kgal})$ ) and removed from service. Administrative interim stabilization was completed in August 1979 and intrusion prevention in December 1982. 
This tank is a high-heat-load tank, although not on a Watch List, and is actively ventilated. All monitoring systems were in compliance with documented standards as of January 31 , 1996 (Hanlon 1996).

\subsection{TANK DESIGN AND BACKGROUND}

The 241-SX Tank Farm was built between 1953 and 1954, and consists of fifteen type IV, $3,800-\mathrm{kL}(1,000-\mathrm{kgal})$ single-shell tanks. Nine of these tanks were the first tanks designed for self-boiling waste, and the original construction included underground duct headers connected to a common condenser-ventilation system. These tanks were designed for a maximum temperature of $121^{\circ} \mathrm{C}\left(250^{\circ} \mathrm{F}\right), \mathrm{pH}$ values from eight to ten, and a boiling period of one to five years. Tank 241-SX-108 has four air lift circulators to help prevent sludge settling and to control waste temperatures. This tank is equipped to cascade to tank 241-SX-109 and is second in the three-tank step series cascade that includes tank 241-SX-107. Tank 241-SX-108 has 22 risers ranging in size from $64 \mathrm{~mm}(2.5 \mathrm{in}$.) to 460 $\mathrm{mm}$ (18 in.) in diameter that provide surface level access to the underground tank. Tank 241-SX-108 has three 305-mm (12-in.)-diameter risers (numbers 7, 16, and 17) available for use. If used as sampling ports, the risers would give access to a moderate area near the middle of the tank.

Tank 241-SX-108 entered service in November of 1955. The single-shell tank is constructed of $610-\mathrm{mm}$ (2-ft)-thick concrete on the lower portion of the tank walls and $380-\mathrm{mm}$ (1.25-ft)-thick reinforced concrete on the upper part of the walls. The liner on the bottom and sides is $9.5-\mathrm{mm}(0.375$-in.) mild carbon steel. The dome of the tank is $380-\mathrm{mm}$ (1.25-ft)-thick concrete. This tank has a 305-mm (12-in.) dish bottom, no knuckle, a 9.53-m (31.25-ft) liner height, and a 9.1-m (30-ft) operating depth. The tank is set on a reinforced concrete foundation. Various coatings and sealants were used to seal the inside and outside of the liner, dome, risers, and manholes to prevent leaks and intrusions. The steel liner and risers were given one coat of red lead paint. The exposed interior concrete surfaces were given three coats of magnesium zincfluorosilicate. The tank was covered with approximately $2.2 \mathrm{~m}(7.25 \mathrm{ft})$ of overburden.

The tank surface level is monitored quarterly with a manual tape through riser number 2. A list of tank 241-SX-108 risers, showing the size and general use, is provided in Table 2-2. A plan view that depicts the riser configuration and relative locations is shown as Figure 2-1. A tank cross-section showing the approximate waste level along with a schematic of the tank equipment is found in Figure 2-2. This constitutes all installed equipment for tank 241-SX-108. 
WHC-SD-WM-ER-582, Rev. 0

Table 2-2. Tank 241-SX-108 Risers. ${ }^{1,2}$ (2 sheets)

\begin{tabular}{|c|c|c|}
\hline Triser & 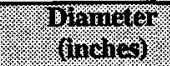 & . Dasorption and Coummons \\
\hline $\mathbf{R 1}$ & 4 & Pit drain \\
\hline$\overline{\mathbf{R 2}}$ & 4 & Liquid level reel in housing \\
\hline$\overline{\mathbf{R 3}}$ & 4 & Thermocouple tree - unused \\
\hline$\overline{\mathbf{R 4}}$ & 4 & Covered with concrete \\
\hline $\mathbf{R 5}$ & 12 & Pump \\
\hline$\overline{\text { R6 }}$ & 12 & Weather covered \\
\hline R7 & 12 & Flange, spare, benchmark \\
\hline $\mathbf{R 8}$ & 12 & Air circulator lines \\
\hline $\mathbf{R 9}$ & 2.5 & Thermocouple tree, to CASS \\
\hline$\overline{R 10}$ & $\overline{2.5}$ & Thermocouple tree, to CASS, weather covered \\
\hline$\tilde{\mathbf{R}} 11$ & 2.5 & Thermocouple tree, to CASS, weather covered \\
\hline$\overline{\mathrm{R} 12}$ & 2.5 & Thermocouple tree, to CASS, weather covered \\
\hline R13 & 42 & Caisson \\
\hline R13A & 18 & Air inlet filter \\
\hline$\overline{\mathrm{R} 14}$ & 2.5 & Thermocouple tree, to CASS, weather covered \\
\hline$\overline{\mathbf{R} 15}$ & 2.5 & Thermocouple tree, to CASS, weather covered \\
\hline R16 & 12 & Flange with bale \\
\hline$\overline{\mathbf{R} 17}$ & 12 & Observation port, benchmark \\
\hline R18 & 2.5 & Thermocouple tree, to CASS, weather covered \\
\hline $\bar{R} 19$ & 2.5 & Thermocouple tree, to CASS, weather covered \\
\hline $\mathbf{R 2 0}$ & 18 & Exhauster port \\
\hline$\overline{\mathbf{R} 21}$ & 12 & Thermocouple tree - unused \\
\hline 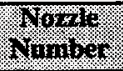 & 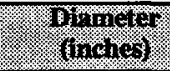 & W. \\
\hline N1 & 5 & Spare nozzle \\
\hline $\mathbf{N 2}$ & $\overline{4}$ & Cascade inlet nozzle \\
\hline N3 & 4 & Cascade outlet nozzle \\
\hline N4 & 3.5 & Spare nozzle \\
\hline N5 & 4 & Sludge level measurement \\
\hline
\end{tabular}

Notes:

CASS = Computer automated surveillance system

'Alstad (1993)

'Hanford Site Drawings:

H-2-33907, Rev. 1 (Isochem Incorporated 1968)

H-2-34064, Rev. 2 (Isochem Incorporated 1970)

H-2-73211, Rev. 2 (Vitro 1985)

H-2-36568, Rev. 0 (Atlantic Richfield Hanford Company 1972) 
Figure 2-1. Riser Configuration for Tank 241-SX-108.

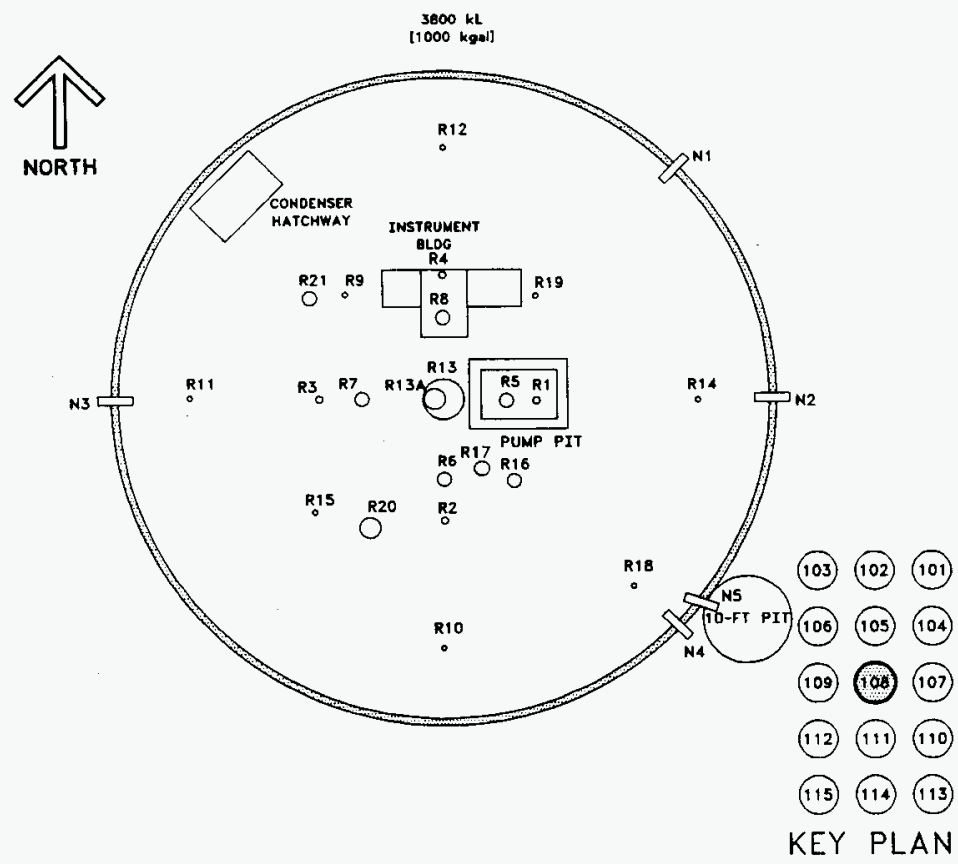


Figure 2-2. Tank 241-SX-108 Configuration.

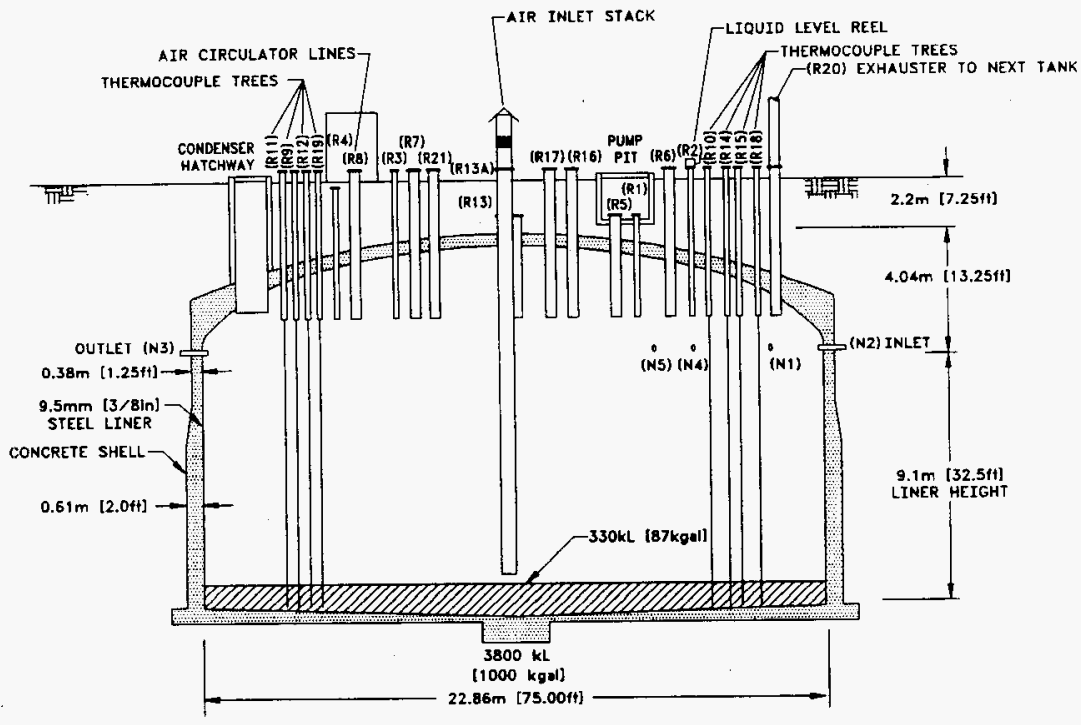

\subsection{PROCESS KNOWLEDGE}

These sections present the transfer history of tank 241-SX-108 and describe the process wastes that made up these transfers. This is followed by an estimate of current tank contents based on transfer history.

\subsubsection{Waste Transfer History}

Reduction-oxidation (REDOX) high-level waste produced in the S Plant REDOX process from 1952 to 1957 is referred to as R1 waste. REDOX high-level waste produced from 1958 to 1966 is referred to as R2 waste. REDOX Plant R1 and R2 wastes were transferred to tank 241-SX-108 from 1955 to 1964. 
The tanks in the 241-SX tank farm were self-boiling tanks, and tank 241-SX-108 was connected to an exhauster. As a result, waste contained within tank 241-SX-108 became self concentrated. The condensate from the self-boiling process was directed back to the tank to maintain an even cooling rate on those occasions when the heat load on the ventilation system increased.

Frequent transfers from tanks 241-SX-105, 241-SX-106, and 241-SX-115 in the 241-SX Tank Farm were made to tank 241-SX-108 from 1959 to 1963 . These transfers involved condensate from self-boiling actions, as well as $R 1$ and $R 2$ waste.

Approximately $329 \mathrm{~kL}(87 \mathrm{kgal})$ of waste remained in tank $241-\mathrm{SX}-108$ after the final waste removal in 1974.

Table 2-3. Summary of Tank 241-SX-108 Waste Transfer History. ${ }^{1}$

\begin{tabular}{|c|c|c|c|c|}
\hline \multirow{2}{*}{ Monoser } & \multirow{2}{*}{ 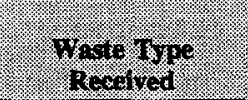 } & \multirow{2}{*}{ 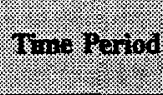 } & \multicolumn{2}{|c|}{ Hetran in } \\
\hline & & & III) & $610+11016$ \\
\hline $\begin{array}{c}\text { S Plant } \\
\text { (REDOX) }\end{array}$ & $\begin{array}{c}\text { REDOX high-level } \\
\text { waste } \\
\text { (R1 and R2) }\end{array}$ & $1955-1964$ & 10,369 & 2,739 \\
\hline SX-106 & Condensate waste & $1959-1963$ & 2,162 & 571 \\
\hline SX-105 & $\begin{array}{c}\text { REDOX } \\
\text { high-level waste (R1) }\end{array}$ & $1962-1963$ & 1,495 & 395 \\
\hline SX-115 & $\begin{array}{c}\text { REDOX } \\
\text { high-level waste } \\
(\mathrm{R} 1 \text { and } R 2)\end{array}$ & 1963 & 64 & 17 \\
\hline
\end{tabular}

Notes:

\footnotetext{
${ }^{1}$ Agnew et al. (1995b)

${ }^{2}$ Waste volumes and types are best estimates based on historical date.
}

\subsubsection{Historical Estimation of Tank Contents}

An estimate of the current contents of Tank 241-SX-108 based on historical transfer data is available from the Historical Tank Content Estimate (HTCE) for the Southwest Quadrant of the Hanford 200 West Area (Brevick et al. 1994b). The historical data used for the estimate are found in the Waste Starus and Transaction Record Summary for the Southwest Quadrant (WSTRS) (Agnew et al. 1995b), the Hanford Defined Waste: Chemical and Radionuclide Compositions (HDW) (Agnew 1995), and the Tank Layer Model for Northeast, Southwest, and Northwest Quadrants (TLM) (Agnew et al. 1995a). The WSTRS is a compilation of available waste transfer and volume status data. The HDW provides the assumed typical compositions for Hanford waste types. In most cases, the available data is incomplete 
reducing the reliability of the transfer data and the modeling results derived from it. The TLM takes the WSTRS data, models the waste deposition processes, and, using additional data from the HDW (which may introduce more error), generates an estimate of the tank contents. Thus, these model predictions can only be considered an estimate that requires further evaluation using analytical data.

The HTCE (Brevick et al. 1994a) states that tank 241-SX-108 contains, from the bottom to the top, $102 \mathrm{~kL}$ (27 kgal) of type R1 waste (REDOX high-level waste generated between 1952 and 1957) and $333 \mathrm{~kL}$ (88 kgal) of type R2 waste (REDOX high-level waste generated between 1958 and 1966). This statement conflicts with the current status given in the Waste Tank Summary Report for Month Ending January 31, 1996 (Hanlon 1996). It is noted in the source document (WSTRS) that there was a change in the tank level status in 1993 from $435 \mathrm{~kL}(115 \mathrm{kgal})$ to $330 \mathrm{~kL}(87 \mathrm{kgal})$. The conflict will be resolved as more information becomes available.

The waste is stratified, and the largest layer is the bottom layer, consisting of $R 1$ waste. The top layer consists of R2 waste. The R1 sludge layer should contain large quantities of aluminum, iron, chromium, sodium, and nitrites. This waste type will also contain notable quantities of uranium, plutonium, strontium, and cesium. The strontium and cesium quantities are enough to give this waste a large activity. As expected, the $R 2$ waste composition is very similar to the R1 waste composition. The two waste types can be distinguished by observing that particular $\mathbf{R} 2$ sludge constituent concentrations will be larger than the same constituents found in the $\mathrm{Rl}$ sludge. The constituents are defined as chromium, nitrate, uranium, plutonium, cesium, and strontium. The activity of the R2 layer will be much higher than the R1 layer. The waste constituents in the HTCE for tank 241-SX-108 and their concentrations are presented in Table 2-5.

Figure 2-3. Tank Layer Model for Tank 241-SX-108.

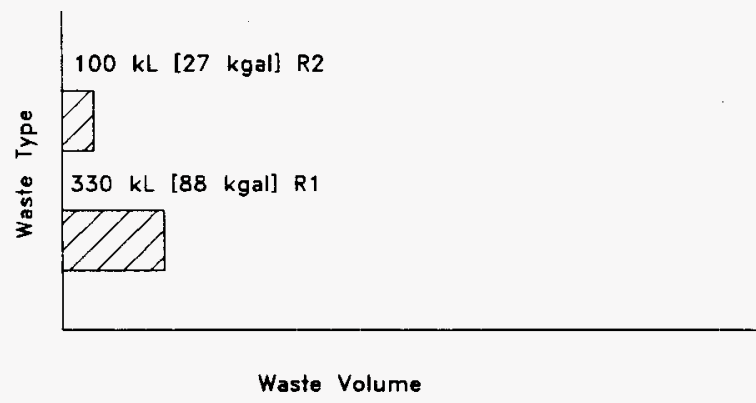


WHC-SD-WM-ER-582, Rev. 0

Table 2-5. Tank 241-SX-108 Inventory Estimate

Based on Historical Tank Content Estimate. ${ }^{1,2,3}$ (2 sheets)

\begin{tabular}{|c|c|c|c|}
\hline \multicolumn{4}{|c|}{ Solud Conjoctio nyentory Estriale } \\
\hline \multicolumn{4}{|c|}{ 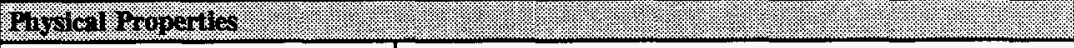 } \\
\hline Total solid waste & \multicolumn{3}{|c|}{$6.76 \mathrm{E}+05 \mathrm{~kg}(115 \mathrm{kgal})$} \\
\hline Heat load & \multicolumn{3}{|c|}{$7.48 \mathrm{~kW}(25,500 \mathrm{Btu} / \mathrm{hr})$} \\
\hline Bulk density & \multicolumn{3}{|l|}{$1.55(\mathrm{~g} / \mathrm{mL})$} \\
\hline Void fraction & \multicolumn{3}{|l|}{0.782} \\
\hline Water wt\% & \multicolumn{3}{|l|}{61.5} \\
\hline $\begin{array}{l}\text { Total organic carbon } \\
\text { wt\% carbon (wet) }\end{array}$ & \multicolumn{3}{|l|}{0} \\
\hline 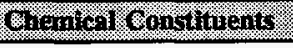 & molde: & 20 & (18. \\
\hline $\mathrm{Na}^{+}$ & 2.84 & 42,000 & 28,400 \\
\hline $\mathrm{Al}^{3+}$ & 4.49 & 77,900 & 52,700 \\
\hline $\mathrm{Fe}^{3+}$ (total Fe) & 0.914 & 32,800 & 22,200 \\
\hline $\mathrm{Cr}^{3+}$ & 1.20 & 40,300 & 27,300 \\
\hline $\mathrm{Bi}^{3+}$ & 0 & 0 & 0 \\
\hline $\mathrm{La}^{3+}$ & 0 & 0 & 0 \\
\hline $\mathrm{Ce}^{3+}$ & 0 & 0 & 0 \\
\hline $\mathrm{Zr}$ (as $\left.\mathrm{ZrO}(\mathrm{OH})_{2}\right)$ & 0 & 0 & 0 \\
\hline $\mathrm{Pb}^{2+}$ & 0 & 0 & 0 \\
\hline $\mathrm{Ni}^{2+}$ & 0.0432 & 1,630 & 1,100 \\
\hline $\mathrm{Sr}^{2+}$ & 0 & 0 & 0 \\
\hline $\mathrm{Mn}^{4+}$ & 0 & 0 & 0 \\
\hline $\mathrm{Ca}^{2+}$ & 0.0960 & 2,480 & 1,680 \\
\hline $\mathbf{K}^{+}$ & 0 & 0 & 0 \\
\hline $\mathrm{OH}^{-}$ & 20.5 & $2.25 \mathrm{E}+05$ & $1.52 \mathrm{E}+05$ \\
\hline $\mathrm{NO}_{3}$ & 2.01 & 80,300 & 54,300 \\
\hline $\mathrm{NO}_{2}^{-}$ & 0 & 0 & 0 \\
\hline $\mathrm{CO}_{3}^{2-}$ & 0.0960 & 3,710 & 2,510 \\
\hline $\mathrm{PO}_{4}{ }^{3}$ & 0 & 0 & 0 \\
\hline $\mathrm{SO}_{4}^{2}$ & 0.0167 & 1,040 & 700 \\
\hline $\mathrm{Si}\left(\right.$ as $\left.\mathrm{SiO}_{3}{ }^{2}\right)$ & 0.243 & 4,400 & 2,970 \\
\hline$F$ & 0 & 0 & 0 \\
\hline
\end{tabular}


Table 2-5. Tank 241-SX-108 Inventory Estimate Based on Historical Tank Content Estimate. ${ }^{1,2,3}$ (2 sheets)

\begin{tabular}{|c|c|c|c|}
\hline $\mathrm{Cl}^{-}$ & 0.0420 & 958 & 648 \\
\hline 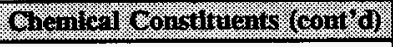 & noler 13: & (1) $\mathrm{ppm}$ & 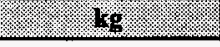 \\
\hline Citrate & 0 & 0 & 0 \\
\hline EDTA $^{4}$ & 0 & 0 & 0 \\
\hline HEDTA $^{3-}$ & 0 & 0 & 0 \\
\hline $\mathrm{NTA}^{3}$ & 0 & 0 & 0 \\
\hline glycolate & 0 & 0 & 0 \\
\hline acetate- & 0 & 0 & 0 \\
\hline oxalate ${ }^{2-}$ & 0 & 0 & 0 \\
\hline DBP & 0 & 0 & 0 \\
\hline NPH & 0 & 0 & 0 \\
\hline $\mathrm{CCl}_{4}$ & 0 & 0 & 0 \\
\hline hexone & 0 & 0 & 0 \\
\hline $\mathrm{Fe}(\mathrm{CN})_{6}{ }^{4}$ & 0 & 0 & 0 \\
\hline 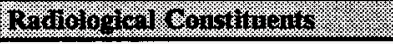 & W11. & 60 & 8 \\
\hline $\mathrm{Pu}$ & & 0.0130 & $0.146(\mathrm{~kg})$ \\
\hline $\mathrm{U}$ & $0.0621(\mathrm{M})$ & $9,510(\mu \mathrm{g} / \mathrm{g})$ & $6,430(\mathrm{~kg})$ \\
\hline Cs & 0.0959 & 61.7 & 41,700 \\
\hline $\mathrm{Sr}$ & 2.48 & 1,600 & $1.08 \mathrm{E}+06$ \\
\hline
\end{tabular}

Notes:

'Agnew (1995b)

The HTCE predictions have not been validated and should be used with caution.

${ }^{3}$ Small differences appear to exist among the inventory above and the inventories calculated from the two sets of concentrations. These differences are being evaluated.

\subsection{SURVEILLANCE DATA}

Tank 241-SX-108 surveillance consists of surface level measurements (liquid and solid), temperature monitoring inside the tank (waste and headspace), and leak detection well (drywell) monitoring for radioactivity outside the tank. The data are significant because they provide the basis for determining tank integrity.

Liquid level measurement can provide an indicator of whether or not the tank has a significant leak. Solid surface level measurements provide an indication of surface level and changes in surface level, and can be used to detect changes in the consistency and density of 
solid layers of waste in the tank. If leakage to the soil occurs, radiation monitors in drywells located around the perimeter of the tank may show increased radioactivity due to leakage out to the soil. Inspecting and interpreting photographs of the tank's interior is another method of determining the presence of water in the waste, estimating waste height, helping to resolve some measurement anomalies, and determining tank integrity.

\subsubsection{Surface Level Readings}

Tank 241-SX-108's surface level is monitored quarterly with a manual tape through riser 2. From 1991 to the end of 1993, the surface level of the waste remained steady at $940 \mathrm{~mm}$ (37 in.). Fluctuations were observed in the surface level readings during the first and second quarters of 1994 . The readings finally leveled out at $826 \mathrm{~mm}(32.5)$ in July 1994, and have remained consistent ever since. The most recent manual tape reading was $826 \mathrm{~mm}(32.5 \mathrm{in}$.) on April 2, 1996. A graphical representation of the quarterly surface level measurements can be found in Figure 2-4.

Tank 241-SX-108 does not have a liquid observation well.

\subsubsection{Internal Tank Temperatures}

Tank 241-SX-108 has eight thermocouple trees in risers 9 to 12, 14, 15, 18, and 19. Thermocouple trees $1,3,4,5$, and 7 have 4 thermocouples per tree. Thermocouple trees 2 and 8 have 6 thermocouples per tree. Riser 21 was used previously to record temperature data. Data are not available for thermocouple tree 6 in riser 15 . Only thermocouple trees 2 and 8 have thermocouples with more than three recorded data points. The highest reading for tree 2 on November 5,1995 was $88^{\circ} \mathrm{C}\left(191^{\circ} \mathrm{F}\right)$ recorded by thermocouple 1 . The highest reading for tree 8 on November 5, 1995 was $91^{\circ} \mathrm{C}\left(196^{\circ} \mathrm{F}\right)$ recorded by thermocouple 1 .

Thermocouples 1 and 3 on tree 2 have temperature readings recorded from January 1989 to December 1993. For thermocouple 1 , the maximum temperature is $101^{\circ} \mathrm{C}\left(213{ }^{\circ} \mathrm{F}\right)$, the minimum temperature is $84^{\circ} \mathrm{C}\left(184^{\circ} \mathrm{F}\right)$, and the average temperature is $91^{\circ} \mathrm{C}\left(195^{\circ} \mathrm{F}\right)$. For thermocouple 3 , the maximum temperature is $86^{\circ} \mathrm{C}\left(187^{\circ} \mathrm{F}\right)$, the minimum temperature is $53{ }^{\circ} \mathrm{C}\left(128^{\circ} \mathrm{F}\right)$, and the average temperature is $63^{\circ} \mathrm{C}\left(145^{\circ} \mathrm{F}\right)$. Thermocouples 2 and 4 on tree 2 have temperature readings recorded from January 1990 to December 1993. For thermocouple 2, the maximum temperature is $81^{\circ} \mathrm{C}\left(178^{\circ} \mathrm{F}\right)$, the minimum temperature is $70^{\circ} \mathrm{C}\left(158^{\circ} \mathrm{F}\right)$, and the average temperature is $77^{\circ} \mathrm{C}\left(171^{\circ} \mathrm{F}\right)$. For thermocouple 4 , the maximum temperature is $61^{\circ} \mathrm{C}\left(141^{\circ} \mathrm{F}\right)$, the minimum temperature is $51^{\circ} \mathrm{C}\left(124{ }^{\circ} \mathrm{F}\right)$, and the average temperature is $57^{\circ} \mathrm{C}\left(135^{\circ} \mathrm{F}\right)$. Thermocouples 5 and 7 on tree 2 have temperature readings recorded from January 1989 to July 1991. For thermocouple 5, the maximum temperature is $65^{\circ} \mathrm{C}\left(149^{\circ} \mathrm{F}\right)$, the minimum temperature is $56^{\circ} \mathrm{C}\left(133^{\circ} \mathrm{F}\right)$, and the average temperature is $61^{\circ} \mathrm{C}\left(141^{\circ} \mathrm{F}\right)$. For thermocouple 7 , the maximum temperature 
is $65^{\circ} \mathrm{C}\left(149^{\circ} \mathrm{F}\right)$, the minimum temperature is $54^{\circ} \mathrm{C}\left(129^{\circ} \mathrm{F}\right)$, and the average temperature is $58^{\circ} \mathrm{C}\left(137^{\circ} \mathrm{F}\right)$.

Thermocouples on tree 8 have temperature readings recorded from January 1989 to December 1993. For thermocouple 1 , the maximum temperature is $107^{\circ} \mathrm{C}\left(224^{\circ} \mathrm{F}\right)$, the minimum temperature is $87^{\circ} \mathrm{C}\left(188^{\circ} \mathrm{F}\right)$, and the average temperature is $92^{\circ} \mathrm{C}\left(200^{\circ} \mathrm{F}\right)$. This maximum temperature is the highest temperature recorded for any of the Hanford Site's single-shell tanks. For thermocouple 2, the maximum temperature is $78^{\circ} \mathrm{C}\left(172{ }^{\circ} \mathrm{F}\right)$, the minimum temperature is $60^{\circ} \mathrm{C}\left(140^{\circ} \mathrm{F}\right)$, and the average temperature is $74^{\circ} \mathrm{C}\left(166^{\circ} \mathrm{F}\right)$. For thermocouple 3 , the maximum temperature is $86^{\circ} \mathrm{C}\left(186^{\circ} \mathrm{F}\right)$, the minimum temperature is $47^{\circ} \mathrm{C}\left(117^{\circ} \mathrm{F}\right)$, and the average temperature is $61^{\circ} \mathrm{C}\left(141^{\circ} \mathrm{F}\right)$. For thermocouple 4 , the maximum temperature is $62^{\circ} \mathrm{C}\left(143{ }^{\circ} \mathrm{F}\right)$, the minimum temperature is $50^{\circ} \mathrm{C}\left(122^{\circ} \mathrm{F}\right)$, and the average temperature is $58^{\circ} \mathrm{C}\left(137^{\circ} \mathrm{F}\right)$. For thermocouple 5 , the maximum temperature is $66^{\circ} \mathrm{C}\left(150^{\circ} \mathrm{F}\right)$, the minimum temperature is $53^{\circ} \mathrm{C}\left(127^{\circ} \mathrm{F}\right)$, and the average temperature is $58^{\circ} \mathrm{C}\left(137^{\circ} \mathrm{F}\right)$. For thermocouple 7 , the maximum temperature is $66^{\circ} \mathrm{C}\left(151^{\circ} \mathrm{F}\right)$, the minimum temperature is $53{ }^{\circ} \mathrm{C}\left(127^{\circ} \mathrm{F}\right)$, and the average temperature is $59^{\circ} \mathrm{C}\left(139^{\circ} \mathrm{F}\right)$.

Examining temperature readings taken on January 20, 1989 reveals a relatively consistent temperature difference between thermocouple 1 and 7 for all of the thermocouple trees. The lowest temperature difference was for tree 4 which had a $25^{\circ} \mathrm{C}\left(45^{\circ} \mathrm{F}\right)$ delta between thermocouples 1 and 7 . Thermocouple tree 3 had the highest temperature difference between Thermocouples 1 and 7 at $45^{\circ} \mathrm{C}\left(81^{\circ} \mathrm{F}\right)$. The temperature difference between the trees might be attributed to proximity to the walls of the tank or the airlift circulators.

The data for tree 2 shows a slight downward trend in temperature between 1989 and 1993. A similar trend is shown on the graphs for tree 8 except for thermocouple 3 , which has wide variations in temperature between January 1990 and March 1992. Tank 241-SX-108 is a high-heat-load tank with a requirement that temperatures are read monthly (although temperatures are often recorded at a more frequent interval). A graph of the weekly high temperature is shown in Figure 2-5.

Plots of the thermocouple readings for tank 241-SX-108 can be found in the Supporting Document for the Northeast Quadrant Historical Tank Content Estimate Report for SX Tank Farm (Brevick et al. 1994b).

\subsubsection{Drywells}

Tank 241-SX-108 has six drywells. Drywells 41-08-02 (active prior to 1990, current readings $>200$ counts/second (c/s) ), 41-08-04 (active prior to 1990, current readings $<200 \mathrm{c} / \mathrm{s}$ ), 41-08-07 (active prior to 1990 , current readings $>200 \mathrm{c} / \mathrm{s}$ ), and 41-08-11 (active prior to 1990 , current readings $>200 \mathrm{c} / \mathrm{s}$ ) have or had readings greater than the 50 c/s background radiation. Plotted readings for drywells 41-08-02, 41-08-04, 41-08-07, and 41-08-11 taken from April 1990 to January 1994 are available in the Supporting Document for the Historical Tank Content Estimate for SX Tank Farm (Brevick et al. 1994b). 
Figure 2-4. Tank 241-SX-108 Level History.

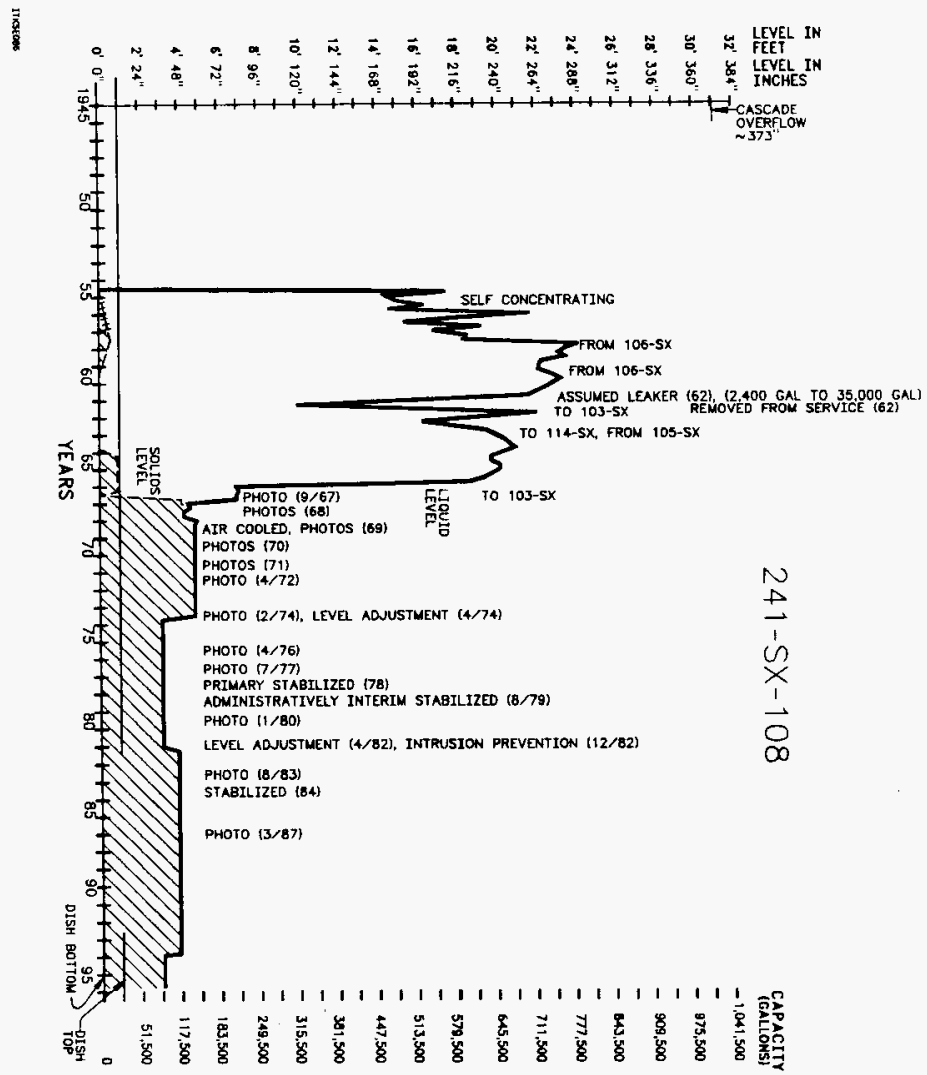


Figure 2-5. Tank 241-SX-108 Weekly High Temperature Plot.

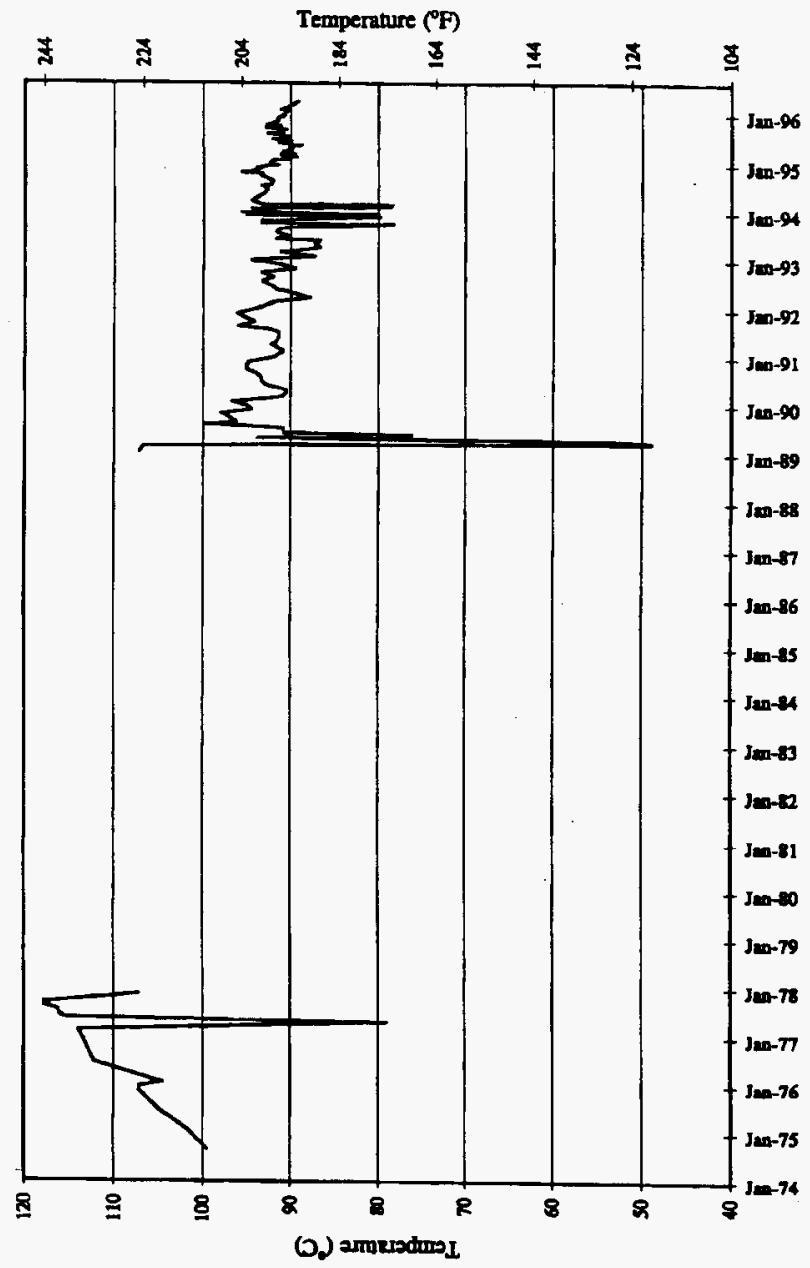




\subsubsection{Tank 241-SX-108 Photograph}

The tank waste appears to be completely dry in the photographic montage. A small amount of brown residue is present on the surface of a light gray solid waste. Because of the low depth of the waste material, the airlift circulators are protruding from the surface of the material. Records indicate that there is a bulge in the bottom of this tank (Atlantic Richfield Company 1967). Thermocouple trees are situated around the perimeter of the tank. Equipment present in the tank includes a turbine pump, a manual tape, risers, and some nozzles. A discarded level measurement tape is on the surface near the center of the tank. 


\subsection{TANK SAMPLING OVERVIEW}

This section describes the September 1995 sampling and analysis event for tank 241-SX-108. Auger samples were taken to satisfy the requirements of the Tank Safety Screening Data Quality Objective (Dukelow et al. 1995), the Strategy for Sampling Hanford Site Tank Wastes for Development of Disposal Technology (Kupfer et al. 1995), and the Historical Model Evaluation Data Requirements (Simpson and McCain 1995). The sampling and analyses were performed in accordance with the Tank 241-SX-108 Auger Sampling and Analysis Plan (Eggers 1995a). Further discussions of the sampling and analysis procedures can be found in the Tank Characterization Reference Guide (DeLorenzo et al. 1994).

\subsection{DESCRIPTION OF SAMPLING EVENT}

Attempts were made to obtain three auger samples of the top $48 \mathrm{~cm}$ (19 in.) of the waste in tank 241-SX-108 from risers 7, 16, and 17. However, no samples were retrieved from riser 17. Two auger samples, 95-AUG-042 and 95-AUG-043, were removed from tank 241-SX-108 through risers 16 and 7 on September 15 and 19, 1995, and were received at the 222-S Laboratory on September 18 and 20, 1995, respectively.

The safety screening DQO requires a vertical profile of the waste from a minimum of two risers separated radially to the maximum extent possible. Because sampling the top of the solid waste with augers does not provide a complete profile of all of the solid waste, the safety screening for this tank will not be completed until cores to the bottom of the tank in at least two risers have been obtained and analyzed.

Primary safety screening analyses are: total alpha activity to determine criticality, DSC to ascertain the fuel energy value, TGA to obtain the total moisture content, bulk density, and tank headspace vapor flammability.

\subsection{SAMPLE HANDLING}

The material recovered from risers 16 and 7 was described as very dry and powdery (Eggers 1995b). Operators working with samples described the material as "dry and flighty" (Eggers 1996). Consistent with this, the auger samples contained no drainable liquid. Also, high dose rates were measured. For these reasons, the analytical laboratory was concerned that problems might occur during the sampling and analysis processes.

Recovered amounts of sample and sample descriptions are summarized in Table 3-1. Each auger sample was divided into lower-half and upper-half samples that were further divided into subsamples for different analytical or archiving requirements as shown in Table 3-2. 
Table 3-1. Tank 241-SX-108 Sample Recovery and Description. ${ }^{\prime}$

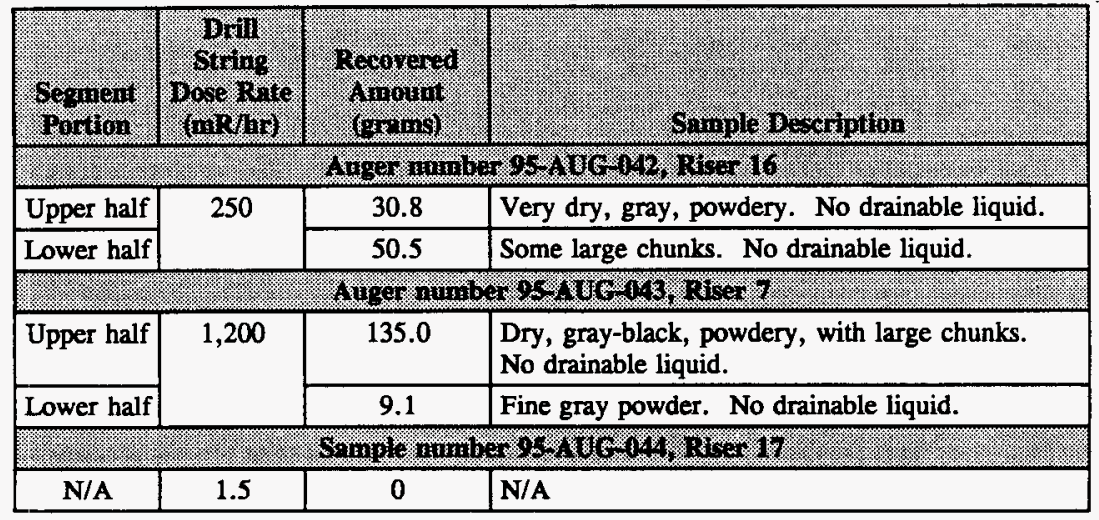

Note:

$$
\text { 'Eggers (1996) }
$$

Table 3-2. Tank 241-SX-108 Subsampling Scheme. ${ }^{1}$

\begin{tabular}{|c|c|c|}
\hline 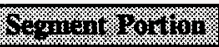 & 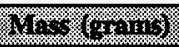 & 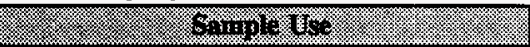 \\
\hline \multicolumn{3}{|c|}{ 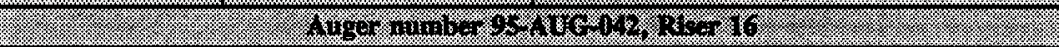 } \\
\hline \multirow[t]{2}{*}{ Upper half } & 10.3 & Safety screening and historical analyses \\
\hline & 20.5 & Archive sample \\
\hline \multirow[t]{3}{*}{ Lower half } & 9.8 & Safety screening and historical analyses \\
\hline & 16.5 & Archive sample \\
\hline & 24.2 & Pretreatment DQO sample sent to PNNL \\
\hline \multicolumn{3}{|c|}{ 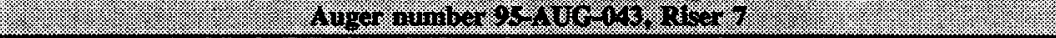 } \\
\hline \multirow[t]{3}{*}{ Upper half } & 9.5 & Safety screening and historical analyses \\
\hline & 60.6 & Archive sample \\
\hline & 30.0 & Pretreatment DQO sample sent to PNNL \\
\hline \multirow[t]{2}{*}{ Lower half } & 4.6 & Safety screening and historical analyses \\
\hline & 2.7 & Archive sample \\
\hline
\end{tabular}

Note:

$$
\text { 'Eggers (1996) }
$$




\subsection{SAMPLE ANALYSIS}

The analyses performed on the auger samples were limited to those required by the safety screening and historical DQOs. Additional samples were set aside and shipped to PNNL in accordance with the pretreatment $\mathrm{DQO}$. The required analyses for the safety screening DQO were exotherm energy by DSC, moisture content by TGA, and fissile content by total alpha activity analyses. The historical DQO required anion concentrations by IC, metal concentrations by ICP, bulk density, specific gravity, TOC by persulfate and coulometry, uranium by phosphorescence, and total beta analysis. Weight percent water for auger 95-AUG-042 was remeasured by gravimetry to verify the TGA results. Auger 95-AUG-043 exhibited dose rates that would have caused exposure to laboratory personnel in excess of what was considered reasonable under the circumstances, and therefore was not subjected to gravimetric analysis.

The analytical results from the September auger sampling and analysis effort are reported in Final Report for Tank 241-SX-108, Auger Samples 95-AUG-042, 95-AUG-043, and 95-AUG-044 (Eggers 1996), and are discussed in Sections 4.0 and 5.0 of this report.

Calibration standards and duplicate measurements were used to check and control all measurements. In addition, for selected measurements, matrix spikes were used to check unspiked sample measurement results. The analytical procedures that used spikes included total alpha, metals measured by ICP, total beta, uranium by phosphorescence, TOC and ions by IC. An assessment of the QC procedures and data is presented in Section 5.1.2 of this report.

A blank segment was analyzed using the following methods: total alpha, gamma energy analysis, strontium $89 / 90$ high level, ICP, TOC by persulfate/coulometry, IC, total beta and uranium by phosphorescence. All reported analyses were performed in accordance with approved laboratory procedures. A list of the sample numbers and applicable analyses is presented in Table 3-3. Table 3-4 shows the analytical procedure by title and number. 
Table 3-3. Summary of Samples and Analyses. ${ }^{1}$ (2 sheets)

\begin{tabular}{|c|c|c|c|c|}
\hline Auger Nomber & Rlser: & Sezuent horthor & Somple Wrinber & Analyses \\
\hline \multirow[t]{15}{*}{ 95-AUG-042 } & \multirow[t]{15}{*}{16} & \multirow[t]{7}{*}{ Upper half } & S95T002480 & $\begin{array}{l}\text { TGA, DSC, } \\
\text { gravimetry, } \\
\text { TOC, }\end{array}$ \\
\hline & & & S95T002481 & $\begin{array}{l}\text { Total alpha, } \\
\text { GEA, high-level } \\
{ }^{90} \mathrm{Sr}\end{array}$ \\
\hline & & & S95T002482 & ICP/acid digest \\
\hline & & & S95T002504 & Archive \\
\hline & & & S95T003881 & IC \\
\hline & & & S95T003882 & ICP/water wash \\
\hline & & & S95T003885 & $\begin{array}{l}\text { Total beta, } \\
\text { uranium }\end{array}$ \\
\hline & & \multirow[t]{8}{*}{ Lower half } & S95T002489 & $\begin{array}{l}\text { TGA, DSC, } \\
\text { gravimetry, } \\
\text { TOC }\end{array}$ \\
\hline & & & S95T002500 & $\begin{array}{l}\text { Total alpha, } \\
\text { GEA, } \\
\text { high-Level }{ }^{\text {\%Sr }}\end{array}$ \\
\hline & & & S95T002501 & ICP/acid digest \\
\hline & & & S95T002502 & $\begin{array}{l}\text { Pretreatment } \\
\text { sample }\end{array}$ \\
\hline & & & S95T002503 & Archive \\
\hline & & & S95T003886 & IC \\
\hline & & & S95T003887 & ICP/water wash \\
\hline & & & S95T003890 & $\begin{array}{l}\text { Total beta, } \\
\text { uranium }\end{array}$ \\
\hline
\end{tabular}


WHC-SD-WM-ER-582, Rev. 0

Table 3-3. Summary of Samples and Analyses.' (2 sheets)

\begin{tabular}{|c|c|c|c|c|}
\hline ruger r vinizer & hatse & 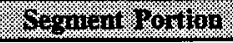 & Snengle rumber & $1101 y=8$ \\
\hline \multirow[t]{13}{*}{ 95-AUG-043 } & \multirow[t]{13}{*}{7} & \multirow[t]{8}{*}{ Upper half } & S95T002567 & TGA, DSC, \\
\hline & & & S95T002572 & $\begin{array}{l}\text { Total alpha, } \\
\text { GEA, high-level } \\
{ }^{90} \mathrm{Sr}\end{array}$ \\
\hline & & & S95T002573 & ICP/acid digest \\
\hline & & & S95T002574 & $\begin{array}{l}\text { Pretreatment } \\
\text { sample }\end{array}$ \\
\hline & & & \$95T002575 & \begin{tabular}{|l|} 
Archive \\
\end{tabular} \\
\hline & & & S95T003891 & IC \\
\hline & & & S95T003892 & ICP/water wash \\
\hline & & & S95T003895 & $\begin{array}{l}\text { Total beta, } \\
\text { uranium }\end{array}$ \\
\hline & & \multirow[t]{5}{*}{ Lower half } & S95T002577 & TGA, DSC \\
\hline & & & S95T002578 & $\begin{array}{l}\text { Total alpha, } \\
\text { GEA, high-level } \\
{ }^{90} \mathrm{Sr}\end{array}$ \\
\hline & & & S95T002579 & ICP/acid digest \\
\hline & & & S95T002580 & Archive \\
\hline & & & $\$ 95 T 000660$ & TOC \\
\hline
\end{tabular}

Note:

${ }^{1}$ Eggens (1996) 
Table 3-4. Analytical Procedures. ${ }^{1}$

\begin{tabular}{|c|c|c|c|}
\hline Analysis & Inctument & $\begin{array}{l}\text { Ireparation } \\
\text { Procedite }\end{array}$ & Proceane rimiber \\
\hline Energetics by DSC & $\begin{array}{l}\text { Mettler }^{\mathrm{TM}} \\
\text { Perkin-Elmer }^{\mathrm{TM}}\end{array}$ & N/A & $\begin{array}{l}\text { LA-514-113, Rev. C-0 } \\
\text { LA-514-114, Rev. C-0 }\end{array}$ \\
\hline $\begin{array}{l}\text { Percent water by } \\
\text { TGA }\end{array}$ & $\begin{array}{l}\text { Mettler }^{\mathrm{TM}} \\
\text { Perkin-Elmer }\end{array}$ & N/A & $\begin{array}{l}\text { LA-560-112, Rev. B-0 } \\
\text { LA-514-114, Rev, C-0 }\end{array}$ \\
\hline $\begin{array}{l}\text { Total alpha } \\
\text { activity }\end{array}$ & $\begin{array}{l}\text { Alpha proportional } \\
\text { counter }\end{array}$ & LA-549-141, Rev.D-0 & LA-508-101, Rev. D-2 \\
\hline Total beta activity & $\begin{array}{l}\text { Beta proportional } \\
\text { counter }\end{array}$ & LA-549-141, Rev. D-0 & LA-508-101, Rev. D-2 \\
\hline${ }^{90}$ Sr activity & $\begin{array}{l}\text { High-level }{ }^{90} \mathrm{Sr} \\
\text { counting }\end{array}$ & LA-549-141, Rev. D-0 & LA-220-101, Rev. D-1 \\
\hline Metals/acid digest & $\begin{array}{l}\text { Inductively coupled } \\
\text { plasma spectrometer }\end{array}$ & LA-505-159, Rev. C-0 & LA-505-161 Rev. B-0 \\
\hline Anions & Ion chromatography & LA-504-101, Rev. E-0 & LA-533-105, Rev. D-1 \\
\hline Total uranium & & LA-549-141, Rev. D-0 & LA-925-009, Rev. A-1 \\
\hline TOC & $\begin{array}{l}\text { Persulfate oxidation/ } \\
\text { coulometry }\end{array}$ & N/A & LA-342-100, Rev. C-0 \\
\hline $\begin{array}{l}\text { Percent water by } \\
\text { gravimetric } \\
\text { analysis }\end{array}$ & $\begin{array}{l}\text { Furnace drying and } \\
\text { sample weighing }\end{array}$ & N/A & LA-564-101, Rev. F-1 \\
\hline Metals/water wash & $\begin{array}{l}\text { Inductively coupled } \\
\text { plasma spectrometer }\end{array}$ & LA-504-101, Rev. E-0 & LA-505-161, Rev. B-0 \\
\hline $\begin{array}{l}\text { Gamma energy } \\
\text { analysis }\end{array}$ & $\begin{array}{l}\text { High-purity } \\
\text { germanium detector }\end{array}$ & $141, \mathrm{Re}$ & , Rev. D-1 \\
\hline
\end{tabular}

Notes:

N/A = not applicable

Rev. = revision

Mettler $^{\text {TM }}$ is a registered trademark of Mettler Electronics, Anaheim, California.

Perkin-Elmer ${ }^{\mathrm{TM}}$ is a registered trademark of Perkins Research and Manufacturing Company, Inc.,

Canoga Park, California.

'Eggers (1996) 


\subsection{ANALYTICAL RESULTS}

\subsection{OVERVIEW}

This section presents a summary of the analytical results associated with the September 1995 sampling of tank 241-SX-108. The sampling and analysis were performed as directed in the Tank 241-SX-108 Auger Sampling and Analysis Plan (SAP) (Eggers 1995a). This plan integrated all documents related to sampling and analytical requirements, including applicable DQOs. The sampling and analytical requirements for augers 95-AUG-042 and 95-AUG-043 were taken from the safety screening DQO (Dukelow et al. 1995), the pretreatment DQO (Kupfer et al. 1995) and the historical model DQO (Simpson and McCain 1995). Analysis of the two augers was performed at the Westinghouse Hanford Company 222-S Laboratory.

The location of analytical results is given in Table 4-1. Comprehensive analytical data are found in Appendix A. Except for physical data, only analyte overall means are reported in Section 4.

Table 4-1. Analytical Data Presentation Tables.

\begin{tabular}{|l|l|}
\hline Chemical data summary & Table 4-2 \\
\hline Thermogravimetric analysis results & Table 4-3 \\
\hline Differential scanning calorimetry & Table 4-4 \\
\hline 1995 comprehensive analytical data & Appendix $A$ \\
\hline
\end{tabular}

Overall means were calculated for all analytes with the exception of DSC. The overall mean for a given analyte was determined by first averaging each of the sample and duplicate pairs to obtain a sample mean. The one exception is the mean for TOC, which is a weighted mean of one auger portion from an auger sample and the mean of two auger portions from the other auger sample. The sample means were then averaged to obtain a subsegment mean, the subsegment means were then averaged to obtain an auger mean, and the two auger means were averaged to obtain the overall mean. The sample, auger, and overall means were each reported as above the detection limit value if 50 percent or more of the contributing values were above the detection limit. If greater than $\mathbf{5 0}$ percent of the values contributing to a particular mean were less than the detection limit (denoted with a "less than" [ $<$ ] symbol), the mean was reported as below the detection limit. The relative standard deviation (RSD) of the mean is a measure of variation and is defined as the standard deviation of the mean divided by the mean, expressed as a percentage.

Quality control tests for the 1995 sampling event included laboratory standard and spike recoveries, tests for blank contamination, and precision checks using the relative percent differences (RPDs) between sample and duplicate analyses. 


\begin{tabular}{|c|c|c|}
\hline $9^{\circ} 6 t$ & $\forall \mathcal{E Z}$ & perI \\
\hline$z \cdot 6 t$ & $I Z I$ & шnบreypur I \\
\hline$I^{\prime} \mathrm{Zt}$ & $006^{\circ} \angle I$ & uorI \\
\hline$\tau^{\prime} \varepsilon b$ & 8.97 & Iəddo? \\
\hline $9^{\circ} \angle \mathrm{I}$ & $L \circ 8 I$ & jeqos \\
\hline$L \mathcal{L E I}$ & $0<0^{\prime} 6$ & 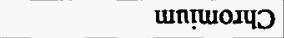 \\
\hline $9^{\circ} L t$ & $86 I$ & แกบุว \\
\hline $20 s$ & OSL'I & uีกฺฺโอ \\
\hline t'SS & $\varepsilon\llcorner L$ & шп!̣peS \\
\hline$\tau \cdot L z$ & $\mathcal{E} O \varepsilon$ & uorog \\
\hline $\mathcal{E} 8 \mathrm{I}$ & $\nabla \cdot 99$ & 4nnusṭg \\
\hline $\mathbf{V} / \mathbf{N}$ & $08^{\circ} \mathrm{Z}>$ & un!!lरIəg \\
\hline$L^{*} S t$ & $6 E I$ & ump̣reg \\
\hline $\mathbf{V} / \mathbf{N}$ & $0^{\circ} 82>$ & ग̣uess \\
\hline $\mathbf{V} / \mathbf{N}$ & ZII $>$ & Kuoumuv \\
\hline$\nabla L E$ & $00 I^{\prime} 8 E$ & unựumiv \\
\hline \% & 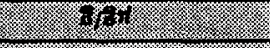 & $53^{2}+3 I_{1}$ \\
\hline 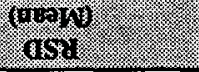 & 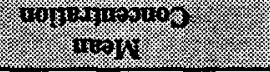 & 416 min \\
\hline
\end{tabular}

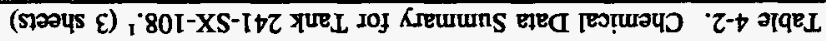

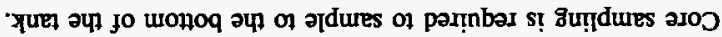

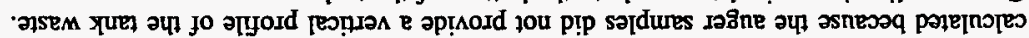

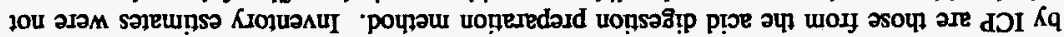

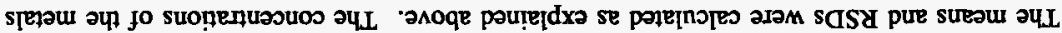

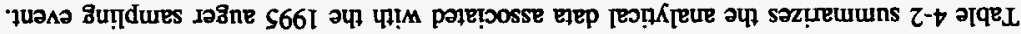

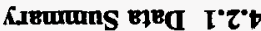

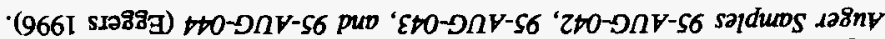

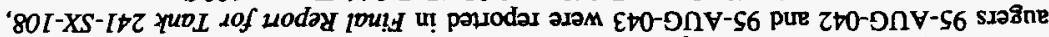

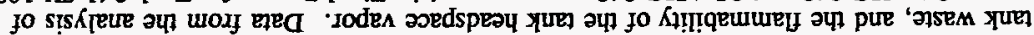

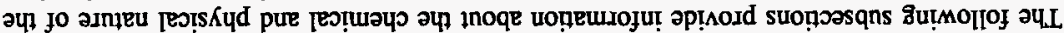

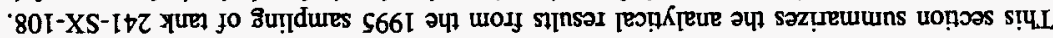

NOILVLNGSAXd VIVT で 
Table 4-2. Chemical Data Summary for Tank 241-SX-108. ${ }^{1}$ ( 3 sheets)

\begin{tabular}{|c|c|c|}
\hline (7) & 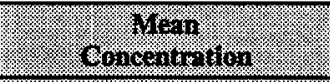 & $\begin{array}{l}17 \text { RSD } \\
\text { Mram }\end{array}$ \\
\hline 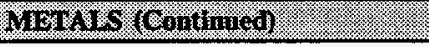 & (2) $19 \mathrm{~g}$ & 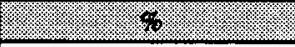 \\
\hline Lithium & 31.8 & 46.4 \\
\hline Magnesium & 269 & 47.0 \\
\hline Manganese & 5,990 & 49.3 \\
\hline Molybdenum & 34.0 & 19.0 \\
\hline Neodymium & 352 & 48.9 \\
\hline Nickel & 1,190 & 46.4 \\
\hline Phosphorous & 134 & 18.1 \\
\hline Potassium & 632 & 47.8 \\
\hline Samarium & 102 & 24.2 \\
\hline Selenium & $<56.6$ & N/A \\
\hline Silicon & 1,090 & 49.1 \\
\hline Silver & 7.52 & 14.0 \\
\hline Sodium & $1.85 \mathrm{E}+05$ & 17.2 \\
\hline Strontium & 563 & 47.9 \\
\hline Sulfur & 1,960 & 40.5 \\
\hline Thallium & $<112$ & N/A \\
\hline Titanium & 43.7 & 43.3 \\
\hline Uranium & 7,540 & 56.5 \\
\hline Vanadium & 34.0 & 19.0 \\
\hline Zinc & 75.2 & 44.9 \\
\hline Zirconium & 433 & 47.1 \\
\hline MOHS & 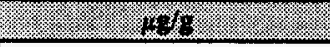 & $1.8 \%$ \\
\hline Bromide & $<1,510$ & N/A \\
\hline Chloride & 2,160 & 23.9 \\
\hline Fluoride & 433 & 58.8 \\
\hline Nitrate & $3.72 \mathrm{E}+05$ & 53.4 \\
\hline Nitrite & 15,700 & 30.0 \\
\hline Oxalate & 3,130 & 42.0 \\
\hline Phosphate & $<1,440$ & N/A \\
\hline Sulfate & 6,890 & 34.0 \\
\hline
\end{tabular}


Table 4-2. Chemical Data Summary for Tank 241-SX-108. ${ }^{1}$ ( 3 sheets)

\begin{tabular}{|c|c|c|}
\hline (inives & (2) & 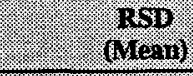 \\
\hline 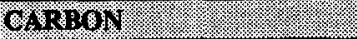 & (1) 18 & \% \\
\hline Total organic carbon & 900 & 86.8 \\
\hline 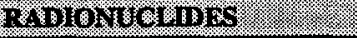 & 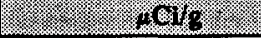 & (2) \\
\hline${ }^{144} \mathrm{Ce} / \mathrm{Pr}$ & $<18.6$ & N/A \\
\hline${ }^{60} \mathrm{Co}$ & $<0.920$ & N/A \\
\hline${ }^{134} \mathrm{Cs}$ & $<1.15$ & N/A \\
\hline${ }^{137} \mathrm{Cs}$ & 195 & 11.2 \\
\hline${ }^{154} \mathrm{Eu}$ & $<43.6$ & N/A \\
\hline${ }^{155} \mathrm{Eu}$ & $<5.17$ & N/A \\
\hline${ }^{94} \mathrm{Nb}$ & $<0.915$ & $\mathbf{N} / \mathbf{A}$ \\
\hline${ }^{226} \mathrm{Ra}$ & $<30.6$ & N/A \\
\hline${ }^{106} \mathrm{Ru} / \mathrm{Rh}$ & $<24.1$ & N/A \\
\hline${ }^{89190} \mathrm{Sr}$ & 3,070 & 52.3 \\
\hline Total beta & 6,930 & 52.1 \\
\hline Total alpha & 3.29 & 45.6 \\
\hline 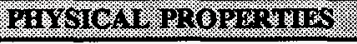 & 4. & (17) \\
\hline Weight percent water (TGA) & 2.03 & 55.1 \\
\hline Weight percent water (Grav.) & 0.475 & 5.3 \\
\hline
\end{tabular}

Note:

'Eggers (1996)

\subsubsection{Physical Data Summary}

Thermal analyses were performed on tank 241-SX-108 auger samples to satisfy the requirements of the safety screening DQO (Dukelow et al. 1995) and the historical DQO (Simpson and McCain 1995). Thermal analyses included differential scanning calorimetry (DSC), thermogravimetric analysis (TGA) and gravimetry. In addition, density measurements were to be performed on the auger samples; however, because of high sample dose rates and the very dry, flighty nature of the samples, bulk density and specific gravity measurements were not performed. 
4.2.2.1 Thermogravimetric Analysis and Gravimetry. In a TGA, the mass of a sample is measured while its temperature is increased at a constant rate. A gas such as nitrogen or air is passed over the sample during the heating to remove any released gases. Any decrease in the weight of a sample represents a loss of gaseous matter from the sample either through evaporation or through a reaction that forms gas phase products. Gravimetry does not use a nitrogen purge and the sample weights are measured once before and once after the procedure.

Table 4-3 shows the TGA percent water data for tank 241-SX-108. The laboratory did not encounter any problems that required samples to be reanalyzed. The mean weight percent water result for the tank was 2.03 percent, with an RSD of 55.1. The TGA data are also reported in Appendix A.

Table 4-3. Thermogravimetric Analysis Results for Tank 241-SX-108. ${ }^{1}$

\begin{tabular}{|c|c|c|c|c|c|c|c|}
\hline \multicolumn{2}{|c|}{ 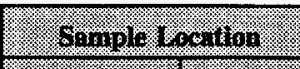 } & \multirow{3}{*}{ 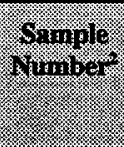 } & \multirow{2}{*}{ 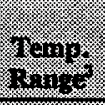 } & \multirow[b]{2}{*}{ isingli: } & \multirow[b]{2}{*}{10101010} & \multirow{2}{*}{ 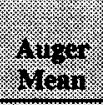 } & \multirow{2}{*}{ 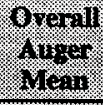 } \\
\hline 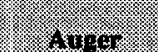 & (2) & & & & & & \\
\hline (4) & 100101 & & (2) & 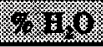 & (4) ह & $x^{2}=18$ & 1618 \\
\hline \multirow[t]{2}{*}{ 95-AUG-042 } & Upper $1 / 2$ & $2480^{4}$ & $\begin{array}{l}35-490 \\
(35-490)\end{array}$ & 2.86 & 3.48 & \multirow[t]{2}{*}{3.15} & \multirow[t]{4}{*}{2.03} \\
\hline & Lower $1 / 2$ & $2489^{4}$ & $\begin{array}{l}35-490 \\
(35-490)\end{array}$ & 2.70 & 3.56 & & \\
\hline \multirow[t]{2}{*}{ 95-AUG-043 } & Upper $1 / 2$ & $2567^{5}$ & $\begin{array}{l}25-225 \\
(25-112)\end{array}$ & 0.591 & 1.621 & \multirow[t]{2}{*}{0.911} & \\
\hline & Lower $1 / 2$ & $2577^{5}$ & $\begin{array}{l}30-250 \\
(30-250)\end{array}$ & 0.535 & 0.897 & & \\
\hline
\end{tabular}

Notes:

'Eggers (1996)

'All semple numbers begin with 'S95T00'.

'Renge in parenthesis is for the duplicate.

"Percent water by thermogravimetric analysis using a Perkin-Elmer ${ }^{\mathrm{rM}}$ instrument.

'Percent water by thermogravimetric analysis using a Mettler ${ }^{\mathrm{M}}$ instrument.

Weight percent water was measured by gravimetry as required by the SAP whenever TGA results are less than 25 weight percent. Auger sample 95-AUG-042 exhibited mean gravimetry results of 0.500 and 0.450 weight percent water of the upper half and lower half auger portions, respectively. Gravimetry was not performed on auger sample 95-AUG-043 because of radiation exposure concerns. 


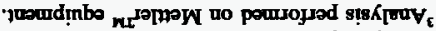
] $(966 \mathrm{I}) \mathbf{s}^{2} 28 \mathrm{~B}_{\mathrm{i}}$ $\cdot$ Kd

\begin{tabular}{|c|c|c|c|c|c|c|}
\hline $8^{\circ} Z L$ & S'96Z & $978^{\circ} I Z$ & $\tau$ & \multirow[b]{4}{*}{ ¿L9SZ00LS6S } & \multirow[b]{2}{*}{$z_{1}$ гәмот } & \multirow[b]{4}{*}{$\varepsilon+0-0 \cap \forall-\varsigma 6$} \\
\hline $6.1 L$ & 6.962 & $I \angle E \angle I$ & I & & & \\
\hline$\nabla 59$ & $L 862$ & EEZOZ & $\tau$ & & \multirow[b]{2}{*}{$z / 1$ Iədd $\Omega$} & \\
\hline$I \cdot L I I$ & $L S 6 Z$ & $E E 9^{\circ} \angle Z$ & I & & & \\
\hline$\tau L I^{\circ} S L$ & $682^{\prime} 662$ & $0 S 6^{\circ} \leftarrow \mathrm{I}$ & $\tau$ & & \multirow[b]{2}{*}{$\psi / 1$ Iәмот } & \multirow[b]{4}{*}{$\tau+0-9 \cap \vee-\varsigma 6$} \\
\hline$L S L ' 16$ & $96 t^{\circ} 962$ & $080^{\circ} 6$ & I & $268 \triangleright z 00 L S 6 S$ & & \\
\hline$\varepsilon 9 \tau^{\circ} 90 \mathrm{I}$ & $0 \angle 0^{\circ} \mathcal{E} O \mathcal{E}$ & $0 t 0^{\circ} \mathrm{sI}$ & $\tau$ & \multirow[b]{2}{*}{$208+2001 S 6 S$} & \multirow[b]{2}{*}{$\psi_{1}$ Iədd $\Omega$} & \\
\hline$\downarrow[9.96$ & $818^{\circ} 862$ & $029^{\circ}$ II & I & & & \\
\hline $\begin{array}{l}4 \% \\
6 \%\end{array}$ & 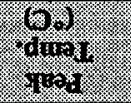 & 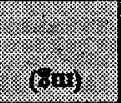 & \multirow[t]{2}{*}{10} & \multirow[t]{2}{*}{ 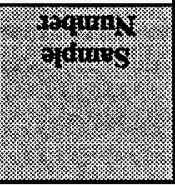 } & 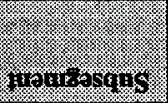 & . \\
\hline \multicolumn{2}{|c|}{ 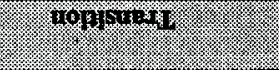 } & 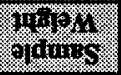 & & & \multicolumn{2}{|c|}{ 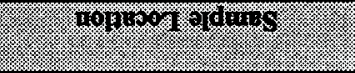 } \\
\hline
\end{tabular}

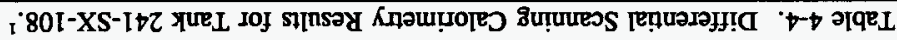

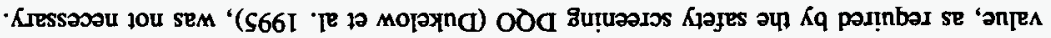

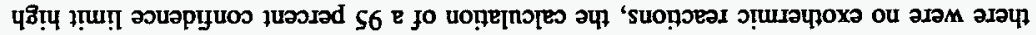

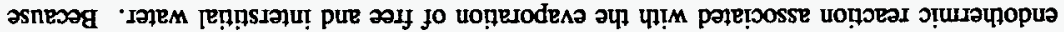

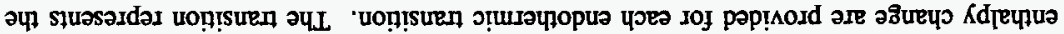

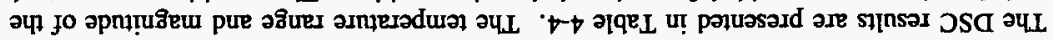

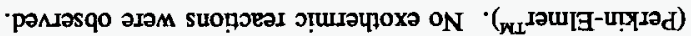

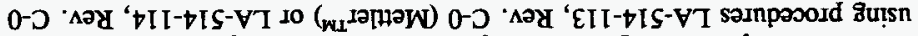

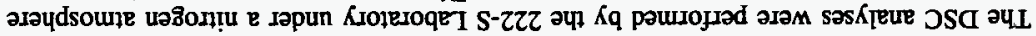

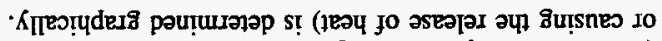

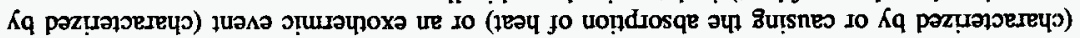

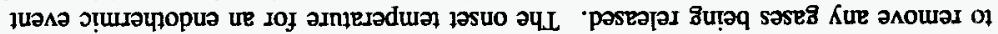

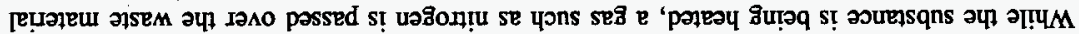

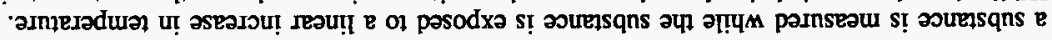

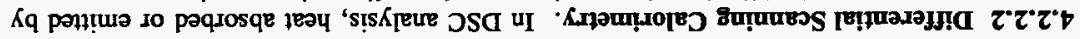


4.2.2.3 Density. Due to high sample dose rates, density measurements could not be carried out in laboratory hoods. An alternate procedure of measuring sample bulk density in the hot cell was considered. However, this procedure calls for centrifugation of the sample material, which in this case was a dry-flighty powder. Because of the dryness and flightiness of the sample material, it was estimated that the measurement results would not be sufficiently accurate to be useful.

\subsubsection{Vapor Data Summary}

The safety screening DQO has established a notification limit of 25 percent of the lower flammability limit for headspace vapors. Prior to removing auger samples, tank vapors were measured for flammability using a combustible gas meter and an organic vapor meter. The concentration of flammable gas was 0 percent of the lower flammability limit. The concentration of ammonia and total organic vapor in the tank headspace were both $0 \mathrm{ppm}$. 
WHC-SD-WM-ER-582, Rev. 0

This page intentionally left blank. 


\subsection{INTERPRETATION OF CHARACTERIZATION RESULTS}

This section evaluates the overall quality and consistency of the available results for tank 241-SX-108 and assesses and compares these results against historical information and program requirements.

\subsection{ASSESSMENT OF SAMPLING AND ANALYTICAL RESULTS}

This section evaluates sampling and analysis factors that may impact the use or interpretation of data. These factors are used to assess the overall quality and consistency of data and to identify limitations in its use.

\subsubsection{Field Observations}

The safety screening DQO (Dukelow et al. 1995) requirement that at least two widely spaced risers be sampled was fulfilled. The requirement for obtaining a vertical profile of the waste was not fulfilled. Sample recoveries were generally fair for the two augers and no anomalies were noted.

\subsubsection{Quality Control Assessment}

The usual quality control (QC) assessment includes an evaluation of the appropriate standard recoveries, spike recoveries, duplicate analyses, and blanks that are performed in conjunction with the chemical analyses. All the pertinent QC tests were conducted on the 1995 auger samples, allowing a full assessment regarding the accuracy and precision of the data. The SAP (Eggers 1995a) established the specific criteria for the primary and secondary analytes required by the safety screening and historical DQOs, whereas the opportunistic analytes were governed by the laboratory criteria (DOE 1995). Quality control results outside the specified criteria for the primary and secondary analytes are identified by footnotes in the Appendix A tables.

The standard and spike recovery results provide an estimate of the accuracy of the analysis. If a standard or spike recovery is above or below the given criterion, then the analytical results may be biased high or low, respectively. The precision is estimated by the relative percent difference (RPD), which is defined as the absolute value of the difference between the primary and duplicate samples, divided by their mean, times one hundred. The only analyte with any standard recoveries outside the criterion was sodium, possibly due to the large dilutions required for samples with high analyte concentrations relative to the detection limit. Uranium, as analyzed by phosphorescence, was the only analyte to have a spike recovery outside the limits. However, this deviation was only a few percent, and the other three spikes conducted with uranium were within the limits. All primary and secondary 
analytes had at least one RPD outside their criterion, but this was likely due to sample heterogeneity. The principles of As Low As Reasonable Achievable, as applied to radiation dose rates, pointed toward not rerunning highly radioactive samples if the results of the initial result and duplicate measurements were fit for use. In the case of weight percent water as determined by TGA and gravimetry, high RPD values were not unreasonable considering the low average values of percent water and the small sample sizes used by the TGA method to determine percent water $(10$ to $20 \mathrm{mg}$ ). None of the samples exceeded the criterion for preparation blanks. Thus, contamination was not a problem for any of the analyses.

In summary, the majority of the QC results were within the boundaries specified in the SAP. Although a number of results were outside their target levels, they were not found to substantially impact either the validity or the use of the data. Because the opportunistic analytes were not specifically requested in the SAP, their QC results are not discussed in this report.

\subsubsection{Data Consistency Checks}

Comparing different analytical methods can help in assessing data consistency and quality. The subsections below provide information regarding the comparison of sulfur as analyzed by ICP with sulfate as analyzed by IC, the comparison of total beta with the sum of the beta emitters, and the calculation of a mass and charge balance.

5.1.3.1 Comparison of Results from Different Analytical Methods. The following data consistency check compares the results from two different analytical methods. A close correlation between the two methods strengthens the credibility of both results, whereas a poor correlation brings the reliability of the data into question. All analytical mean results were taken from Table 4-2.

The ICP sulfur value of $1,960 \mu \mathrm{g} / \mathrm{g}$ converts to $5,870 \mu \mathrm{g} / \mathrm{g}$ of sulfate. This compares well with the IC sulfate result of $6,890 \mu \mathrm{g} / \mathrm{g}$. The RPD between these two sulfate results was 16 percent.

A comparison was made between the total beta activities with the sum of the individual beta emitters. The activities of the individual beta emitters were summed as follows:

$$
\text { Sum of beta emitters }=(2 * 90 \mathrm{Sr})+{ }^{137} \mathrm{Cs} \text {. }
$$

Because ${ }^{90} \mathrm{Sr}$ is in equilibrium with its daughter product ${ }^{90} \mathrm{Y}$, the radiochemically measured value for ${ }^{90} \mathrm{Sr}$ must be multiplied by 2 in order to obtain comparable numbers with total beta. The comparison is shown in Table 5-1. 
Table 5-1. Tank 241-SX-108 Comparison of Gross Beta Activities With the Total of the Individual Activities.

\begin{tabular}{|c|c|c|}
\hline . & $\begin{array}{c}\text { Orerall Mrean } \\
(\text { clog) }\end{array}$ & 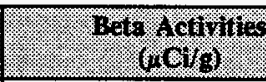 \\
\hline${ }^{90} \mathrm{Sr}$ & 3,070 & 6,140 \\
\hline${ }^{137} \mathrm{Cs}$ & 195 & 195 \\
\hline \multicolumn{2}{|l|}{ Sum of beta emitters } & 6,340 \\
\hline \multicolumn{2}{|l|}{ Gross beta } & 6,930 \\
\hline \multicolumn{2}{|c|}{ Relative percent difference } & $8.9 \%$ \\
\hline
\end{tabular}

5.1.3.3 Mass and Charge Balance. The objectives of the mass and charge balance are to determine if the measurement results are self consistent and if the total concentration of the analytes measured accounts for all significant analytes in the waste. Except for sodium and chromium, cations were assumed to be in a common oxide or hydroxide form that was insoluble. By comparing the concentration of aluminum in samples prepared by the water-wash method to the concentration in samples prepared by the acid digestion method, it was determined that at least 80 percent of the aluminum was insoluble.

Positive and negative charge values were computed and found to agree well with one another for a tank average mixture of analytes. However, the total concentration of the species considered amounted to only 76 to 78 percent of the waste, depending on the breakdown of species assumed.

Adding together all the ICP, IC and TGA results for sample 95-AUG-042 yielded a total of about $900,000 \mu \mathrm{g} / \mathrm{g}$, or about 90 percent of the waste present. Adding the ICP, IC and TGA results for sample 95-AUG-043 yielded only about $450,000 \mu \mathrm{g} / \mathrm{g}$, or only about 45 percent of the waste present.

The biggest difference between the 95-AUG-042 and 95-AUG-043 results was in measurements of nitrate concentration. Sample 95-AUG-042 had a measured nitrate concentration of $571,000 \mu \mathrm{g} / \mathrm{g}$ and sample 95-AUG-043 had a concentration of $173,000 \mu \mathrm{g} / \mathrm{g}$. The analytical laboratory reviewed the data and found no apparent discrepancies in the procedures followed, but suggested that the 95-AUG-043 subsamples be remeasured based on the differences between the 95-AUG-042 and 95-AUG-043 results.

Further review of the measurement data, and of the conclusions reached about tank safety and waste composition, led to the decision to complete the current tank characterization report and delay remeasuring samples until after the end of fiscal year 1996. The reasons for this decision are listed below. (See the detailed information in Section 5.5 for the objectives of this auger sampling event.) 
1. The top $48 \mathrm{~cm}$ (19 in.) of waste at the bottom of the tank has been found to be safe from self-propagating chemical or nuclear chain reactions. Remeasurement of the 95-AUG-043 subsamples by the IC method will not change these results.

2. When the tank headspace gas was sampled, it was found to be safe from self-propagating chemical reactions.

3. The composition of the top $48 \mathrm{~cm}$ (19 in.) of waste passes the historical DQO fingerprint test for REDOX high-level waste. Sample 95-AUG-042 and 95-AUG-043 data pass this test. Remeasurement of $95-A U G-043$ subsamples is not likely to change this conclusion.

4. Tank 241-SX-108 will be completely resampled by the rotary mode method and analyzed in fiscal year 1998 (Stanton 1996)

\subsection{COMPARISON OF HISTORICAL WITH ANALYTICAL RESULTS}

Tank 241-SX-108 was last sampled in 1966. Because of changes in tank composition due to waste transfers between 1966 and 1967, no meaningful comparisons could be made.

\subsection{TANK WASTE PROFILE}

The visual descriptions of the samples from both augers were similar except that some large chunks of material were recovered from the lower half of one auger (95-AUG-042) and from the upper half of the other auger (95-AUG-043). The TLM (Figure 2-3) predicts two different waste types, indicating that some vertical heterogeneity is expected. Based on the length of the auger used, the depth of the waste, and the disposition of the two waste types (according to the TLM), the 1995 auger sampling event probably recovered roughly equal proportions of the two waste types, indicating that some vertical heterogeneity would be expected in the analytical results.

A standard statistical technique known as the analysis of variance (ANOVA) was conducted on the 1995 auger samples in order to determine whether there were horizontal or vertical variations in the analyte concentrations. The test for vertical variation compared the upper and lower half subsegments of each auger. The calculations were performed on all analytes, both DQO driven and opportunistic (except the ICP water digestions), that had half or more of their individual measurements above the detection limit. The ANOVA generates a p-value that is compared with a standard significance level $(\alpha=0.05)$. If a p-value is below 0.05 , there is sufficient evidence to conclude that the sample means are significantly different from each other. However, if a p-value is above 0.05 , there is not sufficient evidence to conclude that the samples are significantly different from each other. 
The results of the ANOVA indicated that there were significant concentration differences between the two augers for 21 of the 45 analytes tested. Vertically, 31 of the 45 analytes showed concentration differences between the upper and lower half subsegments. This information, coupled with the visual description of the samples, indicates that the tank contents vary somewhat both horizontally and vertically.

\subsection{COMPARISON OF TRANSFER HISTORY WTTH ANALYTICAL RESULTS}

The HTCE of the contents of tank 241-SX-108 is shown in Table 5-2 along with the analytical results from the 1995 auger sampling event. This comparison is presented for informational purposes only.

Table 5-2. Comparison of Historical Estimates with the 1995 Analytical Results for Tank 241-SX-108.,2 (2 Sheets)

\begin{tabular}{|c|c|c|c|}
\hline (2) & IHTOr Estimate & 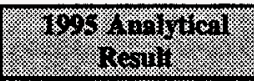 & 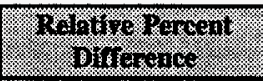 \\
\hline $\mathrm{MMTH}$ & iglos & (2) $/ 1.8 \%$ & (1) \\
\hline Aluminum & 77,900 & 38,100 & 69 \\
\hline Calcium & 2,480 & 1,750 & 35 \\
\hline Chromium & 40,300 & 9,070 & 127 \\
\hline Iron & 32,800 & 17,900 & 59 \\
\hline Nickel & 1,630 & 1,190 & 31 \\
\hline Silicon & 1,620 & 1,090 & 39 \\
\hline Sodium & 42,000 & $1.85 \mathrm{E}+05$ & 126 \\
\hline 101016 & 17ga & (1) & $\sqrt{2}$ \\
\hline Nitrate & 80,300 & $3.72 \mathrm{E}+05$ & 129 \\
\hline Sulfate & 1,040 & 6,890 & 148 \\
\hline 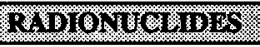 & (2) & the & \% \\
\hline${ }^{137} \mathrm{Cs}$ & $61.7 \mu \mathrm{Ci} / \mathrm{g}$ & $195 \mu \mathrm{Ci} / \mathrm{g}$ & 104 \\
\hline${ }^{89 / 190} \mathrm{Sr}$ & $1,600 \mu \mathrm{Ci} / \mathrm{g}$ & $3,070 \mu \mathrm{Ci} / \mathrm{g}$ & 63 \\
\hline \begin{tabular}{|l|} 
Uranium \\
\end{tabular} & $9,510 \mu \mathrm{g} / \mathrm{g}$ & $7,540 \mu \mathrm{g} / \mathrm{g}$ & 23 \\
\hline Total alpha & $0.0130 \mu \mathrm{Ci} / \mathrm{g}^{3}$ & $3.29 \mu \mathrm{Ci} / \mathrm{g}$ & 198 \\
\hline \multicolumn{3}{|c|}{ 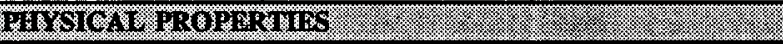 } & $\sqrt{1.83}$ \\
\hline Percent Water & $61.5 \%$ & $2.03 \%$ & 187 \\
\hline
\end{tabular}

Notes:

'Brevick ot al. (1994a) (as updated by Brevick 1995)

${ }^{2}$ Eggers (1996)

${ }^{3}$ Assuming plutonium is the sole contributor. 
Comparing the HTCE with the analytical values produced varied results. A total of 14 analytes were compared. Four of the analytes exhibited RPDs less than 50 percent. Two analytes (total alpha, and weight percent water) exhibited RPDs greater than 150 percent. The RPDs for the remaining eight analytes were in between 50 and 150 percent.

\subsection{EVALUATION OF PROGRAM REQUIREMENTS}

The two tank 241-SX-108 auger samples analyzed at the 222-S Laboratory were acquired to meet the requirements of the safety screening DQO (Dukelow et al. 1995), the pretreatment DQO (Kupfer et al. 1995), and the historical DQO (Simpson and McCain 1995). This section discusses the requirements of the DQOs and compares the analytical data to the defined concentration limits.

\subsubsection{Safety Evaluation}

Data criteria identified in the safety screening DQO are used to assess the waste safety and to check for unidentified safety issues. The DQO requires a vertical profile of the tank waste from two widely spaced risers. Of the five primary analyses required by the DQO, three have decision criteria thresholds that, if exceeded, could warrant further investigation to ensure tank safety. These three analyses include DSC (to measure the fuel content), a determination of total alpha activity to evaluate the criticality potential, and a measurement of the flammability of the tank headspace vapors. Table 5-3 lists the safety issues, the analytes of concern along with their notification limits, and the corresponding analytical results. The safety screening DQO has established a notification limit of $-480 \mathrm{~J} / \mathrm{g}$ (dry weight basis) for exothermic reactions detected during the DSC analysis. No exothermic reactions were observed in any of the tank 241-SX-108 samples.

For criticality reasons, the safety screening DQO limit for total alpha activity is $1 \mathrm{~g} / \mathrm{L}$, or $41 \mu \mathrm{Ci} / \mathrm{g}$ as specified in the SAP. All results were well below the limit, with $5.70 \mu \mathrm{Ci} / \mathrm{g}$ being the largest single result. None of the 95 percent upper confidence level limits for these results exceeded $7.35 \mu \mathrm{Ci} / \mathrm{g}$.

The DQO notification limit for flammable gas concentration is 25 percent of the LFL. Combustible gas meter readings taken at the time of sampling revealed the concentration of flammable gases to be 0 percent of the LFL.

In summary, the September auger core sampling event met all the requirements of the safety screening DQO with the exception of the requirement for a vertical profile of the waste. 
Table 5-3. Safety Screening Data Quality Objective Decision Variables and Criteria.

\begin{tabular}{|c|c|c|c|}
\hline tosion & 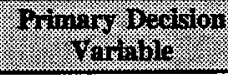 & 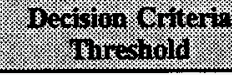 & Hen 6 (n) \\
\hline Ferrocyanide/organics & Total fuel content & $-480 \mathrm{~J} / \mathrm{g}$ & $\begin{array}{l}\text { No exothermic } \\
\text { reactions }\end{array}$ \\
\hline Criticality & Total alpha & $41 \mu \mathrm{Ci} / \mathrm{g}$ & $3.29 \mu \mathrm{Ci} / \mathrm{g}$ \\
\hline Flammable gas & Flammable gas & $\begin{array}{l}25 \text { percent of the } \\
\text { LFL }\end{array}$ & 0 percent of $\mathrm{LFL}$ \\
\hline
\end{tabular}

Another factor in assessing tank waste safety is heat generation and temperature of the waste. Heat is generated in the tanks from radioactive decay. Tank 241-SX-108 has been designated a high-heat tank (non-Watch List), but recent temperature measurements have been below defined limits (Hanlon 1996). An estimate of the heat load was not calculated from the 1995 radionuclide data because only a portion of the waste was sampled. The historical tank content estimate of the heat load was $7.48 \mathrm{~kW}(25,500 \mathrm{Btu} / \mathrm{hr})$, while the heat load based on headspace temperature was $16.4 \mathrm{~kW}(55,900 \mathrm{Btu} / \mathrm{hr})$ (Kummerer 1994). Because an upper temperature limit has been exhibited (Section 2.4.3), it may be concluded that any heat generated from radioactive sources throughout the year is dissipated.

\subsubsection{Pretreatment Evaluation}

As outlined in the SAP, samples of tank 241-SX-108 waste were provided to the Pacific Northwest National Laboratory for pretreatment development testing. Future developments of these tests may provide the basis for revisions of this tank characterization report.

\subsubsection{Historical Evaluation}

In addition to the safety screening DQO, the auger samples were analyzed according to the historical DQO (Simpson and McCain 1995). This DQO strives to quantify the errors associated with the tank waste composition predictions based on waste transaction history and waste type compositions. The DQO identifies key components or "fingerprint" analytes for certain waste types. Tank 241-SX-108 was selected as a tank for historical evaluation because it is expected to contain a thick REDOX waste layer. The first step is to compare the analytical results with DQO-defined concentration levels for the "fingerprint" analytes. This comparison determines whether the predicted waste type is in the tank at the predicted location within the waste matrix. If the analytical results are $\geq 10$ percent of the DQO levels (ratio of 0.1 ), the waste type and layer identification are considered acceptable (Simpson and McCain 1995). 
The lower limit of the fingerprint test window was set at one-tenth of the reference value for the following reasons:

1) The purpose of the fingerprint test is to provide a rough first screening of the waste that will lead to further testing of the waste if the fingerprint test is passed.

2) A single reference value cannot account for the range of conditions found in different tanks; therefore, the lower limit for the test must be set significantly below the reference value.

Table 5-4 compares the concentration levels for REDOX waste from the historical DQO and the 1995 analytical results. All analyses except percent water had analytical results at least 10 percent of the DQO-specified level.

The historical DQO requires that TOC and other analytes be analyzed when the measurement results for the fingerprint analytes pass the fingerprint tests. A notification limit of $30,000 \mu \mathrm{g} \mathrm{C} / \mathrm{g}$ has been established for the measurement of TOC (Eggers 1995a). The TOC results were well below the notification limit, with an overall mean of $900 \mu \mathrm{g} \mathrm{C} / \mathrm{g}$.

Table 5-4. Comparison of Fingerprint Analytes with Analytical Results.

\begin{tabular}{|c|c|c|c|}
\hline 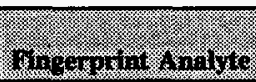 & ind & 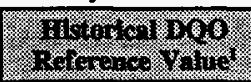 & 2.1.1. \\
\hline Aluminum & $38,100 \mu \mathrm{g} / \mathrm{g}$ & $56,400 \mu \mathrm{g} / \mathrm{g}$ & $0.68^{2}$ \\
\hline Chromium & $9,070 \mu \mathrm{g} / \mathrm{g}$ & $12,500 \mu \mathrm{g} / \mathrm{g}$ & $0.73^{2}$ \\
\hline Sodium & $1.85 \mathrm{E}+05 \mu \mathrm{g} / \mathrm{g}$ & $27,300 \mu \mathrm{g} / \mathrm{g}$ & $6.8^{2}$ \\
\hline${ }^{137} \mathrm{Cs}$ & $195 \mu \mathrm{Ci} / \mathrm{g}$ & $41 \mu \mathrm{Ci} / \mathrm{g}$ & $4.8^{2}$ \\
\hline${ }^{90} \mathrm{Sr}$ & $3,070 \mu \mathrm{Ci} / \mathrm{g}$ & $94 \mu \mathrm{Ci} / \mathrm{g}$ & $33^{2}$ \\
\hline Percent water & $2.03 \%$ & $38-56 \%$ & $0.053^{3}$ \\
\hline
\end{tabular}

Note:

'Simpson and McCain (1995)

${ }^{2}$ Ratio of analytical result to Historical DQO reference value

${ }^{3}$ Ratio of analytical value to lower Historical DQO reference value 
WHC-SD-WM-ER-582, Rev. 0

This page intentionally left blank. 


\subsection{CONCLUSIONS AND RECOMMENDATIONS}

The waste in tank 241-SX-108 was sampled in September 1995. Three DQOs governed the sampling and analysis of augers 95-AUG-042, 95-AUG-043, and 95-AUG-044: the Tank Safery Screening Data Quality Objective (Dukelow et al. 1995), the Strategy for Sampling Hanford Site Tank Wastes for Development of Disposal Technology (Kupfer et al. 1995), and the Historical Model Evaluation Data Requirements (Simpson and McCain 1995). In addition, an internal letter (Kristofzski 1995) directed the laboratories to perform all feasible analyses of the waste samples on an opportunistic basis, according to the work load in the laboratory. All samples were analyzed at the Westinghouse 222-S Laboratory.

Tank 241-SX-108 has been designated a high-heat tank (non-Watch List), but recent temperature measurements have been below defined limits (Hanlon 1996). The historical tank content estimate of heat load was $7.48 \mathrm{~kW}(25,500 \mathrm{Btu} / \mathrm{hr})$, while the heat load based on headspace temperature was $16.4 \mathrm{~kW}(55,900 \mathrm{Btu} / \mathrm{hr})$ (Kummerer 1994). Because the tank exhibits an upper temperature limit, it may be concluded that any heat generated from radioactive sources throughout the year is dissipated.

All analyses met the requirements of the safety screening DQO. No exothermic reactions were observed in the DSC analysis. The total alpha activity mean was $3.29 \mu \mathrm{Ci} / \mathrm{g}$, well below the $\mathrm{DQO}$ notification limit of $41 \mu \mathrm{Ci} / \mathrm{g}$. None of the samples or duplicate samples exhibited total alpha activity greater than the upper 95 percent confidence level of $7.35 \mu \mathrm{Ci} / \mathrm{g}$. Finally, the concentration of flammable gas in the tank headspace was 0 percent of the lower flammability limit. It is recommended that the tank be core sampled to obtain a complete profile of the tank waste and complete the safety assessment. 
WHC-SD-WM-ER-582, Rev. 0

This page intentionally left blank. 


\subsection{REFERENCES}

Alstad, A. T., 1993, Riser Configuration Document for Single-Shell Waste Tanks, WHC-SD-RE-TI-053, Rev. 9, Westinghouse Hanford Company, Richland, Washington.

Agnew, S. F., 1995, Hanford Defined Wastes: Chemical and Radionuclide Compositions, LA-UR-94-2657, Rev. 2, Los Alamos National Laboratory, Los Alamos, New Mexico.

Agnew, S. F., P. Baca, R. Corbin, K. Jurgensen, and B. Young, 1995a, Tank Layer Model (TLM), LA-UR-94-4269, Rev. 1, Los Alamos National Laboratory, Los Alamos, New Mexico.

Agnew, S. F., P. Baca, R. Corbin, T. Duran and K. Jurgensen, 1995b, Waste Status and Transaction Record Summary for the Southwest Quadrant, WHC-SD-WM-TI-614, Rev. 2, Westinghouse Hanford Company, Richland, Washington.

Atlantic Richfield Company Hanford Operations, 1967, Monthly Report, 200 Areas Operation, ARH-60-DEL, Atlantic Richfield Hanford Company, Richland, Washington.

Atlantic Richfield Company Hanford Operations, 1972, Tank 241-SX-108 Isolation, Drawing H-2-36568, Rev. 0, Atlantic Richfield Hanford Company, Richland, Washington.

Brevick, C. H., L. Gaddis, W. Pickett, 1994a, Historical Tank Content Estimate for the Southwest Quadrant of the Hanford 200 West Area, WHC-SD-WM-ER-349, Rev. 0, ICF Kaiser Hanford Company, Richland, Washington.

Brevick, C. H., L. A. Gaddis, E. Johnson, 1994b, Supporting Document for the Historical Tank Content Estimate for SX Tank Farm, WHC-SD-WM-ER-324, Rev. 0, ICF Kaiser Hanford Company, Richland, Washington.

Brevick, C. H., 1995, Partial Tank Characterization Report for Single-Shell Tank 241-SX-108 - E44219, (letter to J. G. Kristofzski, Westinghouse Hanford Company, November 16), ICF Kaiser Hanford Company, Richland, Washington.

DeLorenzo, D. S., A. T. DiCenso, D. B. Hiller, K. W. Johnson, J. H. Rutherford, D. J. Smith, and B. C. Simpson, 1994, Tank Characterization Reference Guide, WHC-SD-WM-TI-648, Rev. 0, Westinghouse Hanford Company, Richland, Washington. 
DOE, 1995, Hanford Analytical Services Quality Assurance Plan, DOE/RL-94-55, Rev. 2, U.S. Department of Energy, Richland, Washington.

Dukelow, G. T., J. W. Hunt, H. Babad, and J. E. Meacham, 1995, Tank Safety Screening Data Quality Objective, WHC-SD-WM-SP-004, Rev. 2, Westinghouse Hanford Company, Richland, Washington.

Ecology, EPA, and DOE, 1996, Hanford Federal Facility Agreement and Consent Order, as amended, Washington State Department of Ecology, U.S. Environmental Protection Agency, and U.S. Department of Energy, Olympia, Washington.

Eggers, R. F., 1995a, Tank 241-SX-108 Auger Sampling and Analysis Plan, WHC-SD-WM-TSAP-007, Rev. 0, Westinghouse Hanford Company, Richland, Washington.

Eggers, R. F., 1995b, 45-Day Safety Screening Results for Tank 241-SX-108, Auger Samples 95-AUG-042, 95-AUG-043 and 95-AUG-044, WHC-SD-WM-DP-151, Rev. 0, Westinghouse Hanford Company, Richland, Washington.

Eggers, R. F., 1996, Final Report for Tank 241-SX-108, Auger Samples 95-AUG-042, 95-AUG-043, and 95-AUG-044, WHC-SD-WM-DP-151, Rev. 1, Westinghouse Hanford Company, Richland, Washington.

Hanlon, B.M., 1996, Waste Tank Summary Report for Month Ending February 29, 1996, WHC-EP-0182-95, Westinghouse Hanford Company, Richland, Washington.

Isochem Incorporated, 1968, 108-SX Tank - Vertical Probe Holes \& Cassion for Horizontal Hole for Sludge Level Detector - Assembly \& Details, Drawing No. H-2-33907, Rev. 1, Sheet 1, ICF Kaiser Hanford, Richland, Washington.

Isochem Incorporated, 1970, Dome Equipment Arrangement Tank 108, Drawing No. H-2-34064, Rev. 2, ICF Kaiser Hanford, Richland, Washington.

Kristofzski, J.G., 1995, "Directions for Opportunistic Analyses", (Letter 75310-95-103 to J.H. Baldwin, September 13), Westinghouse Hanford Company, Richland, Washington.

Kummerer, M., 1994, Topical Report on Heat Removal Characteristics of Waste Storage Tanks, WHC-SD-WM-SARR-010, Rev. 0, Westinghouse Hanford Company, Richland, Washington.

Kupfer, M. J., W. W. Schulz, J. T. Slankas, 1995, Strategy for Sampling Hanford Site Tank Wastes for Development of Disposal Technology, WHC-SD-WM-TA-154, Rev. 1, Westinghouse Hanford Company, Richland, Washington. 
Simpson, B. C., D. J. McCain, 1995, Historical Model Evaluation Data Requirements, WHC-SD-WM-DQO-018, Rev. 0, Westinghouse Hanford Company, Richland, Washington.

Stanton, G. A. Jr., 1996, Baseline Sampling Schedule, Change 96-03, (internal memorandum 75610-96-08 to Distribution, May 31), Westinghouse Hanford Company, Richland, Washington.

Vitro Engineering Corporation, 1985, Piping Waste Tank Isolation 241-SX-108, Drawing No. H-2-73211, Rev. 2, ICF Kaiser Hanford, Richland, Washington. 
WHC-SD-WM-ER-582, Rev. 0

\section{APPENDIX A \\ ANALYTICAL RESULTS \\ SINGLE-SHELL TANK 241-SX-108}




\section{A.1 INTRODUCTION}

Appendix A presents the chemical and radiological characteristics of tank 241-SX-108 in a tabular form, in terms of the specific concentrations of metals, ions, radionuclides, and total carbon. Also included are results for the weight percent water analyses by TGA and gravimetry.

The data table for each analyte lists segment number, sample number, auger portion, an original and duplicate result for each sample, a sample mean, an overall mean for the tank in which all augers and auger portions are weighted equally (with the exception of the mean for TOC), and a relative standard deviation. The data are listed in standard notation for values greater than 0.001 and less than 100,000. Values outside these limits are listed in scientific notation.

The tables are numbered sequentially. The following list presents the table numbers of specific analyte groups.

\section{Analyte Characteristic}

Metals

Anions

Radionuclides

Total Carbon

Weight Percent Water

Uranium by Laser Phosphorescence
Table Number

Table A-1 through Table A-37

Table A-38 through Table A-45

Table A-46 through Table A-57

Table A-58

Table A-59

Table A-60

\section{A.2 ANALYTE TABLE DESCRIPTION}

The "Segment Number" column lists the auger sample number for which the analyte was measured. Sampling rationale, locations, and descriptions of sampling events are discussed in Section 3.0.

Column two lists the LABCORE sample number.

Column three contains the name of the segment portion from which the sample was taken (upper $1 / 2$ or lower $1 / 2$ ).

The 'Result' and 'Duplicate' columns are self-explanatory. The 'Mean' column is the average of the result and duplicate values. All values, including those below the detection level (denoted by a 'less than' symbol, <), were averaged. If both sample values were nondetected, the mean is expressed as a non-detected value. If one or both values were above the detection limit, the mean is expressed as a detected value. Superscript letters on the 
Mean values, for which the corresponding quality control violations are listed below, are quality control flags. Only those analytes specifically requested by the SAP were evaluated with respect to quality control. This is discussed in Sections 3.3 and 5.1.2.

"a" indicates a standard recovery below the QC limit.

" $b$ " indicates a standard recovery above the QC limit.

"c" indicates a spike recovery below the QC limit.

" $d "$ indicates a spike recovery above the QC limit.

" $e$ " indicates that the RPD was outside the QC limits.

" $\mathrm{f}$ " indicates the presence of blank contamination.

The 'Overall Mean' column is a simple mean of both auger portion means, and both auger sample means. The one exception is the mean for TOC, which is a weighted mean of one auger portion from an auger sample and the mean of two auger portions from the other auger sample. Means were assigned a 'detect' or 'non-detect' status depending upon the relative number of non-detected values in the data set. Means for data sets having greater than 50 percent non-detected values were assigned a status of 'non-detect'.

Column 8, "Relative Standard Deviation" (RSD), is a measure of variance defined as the standard deviation divided by the mean. This number is expressed as a percentage. 


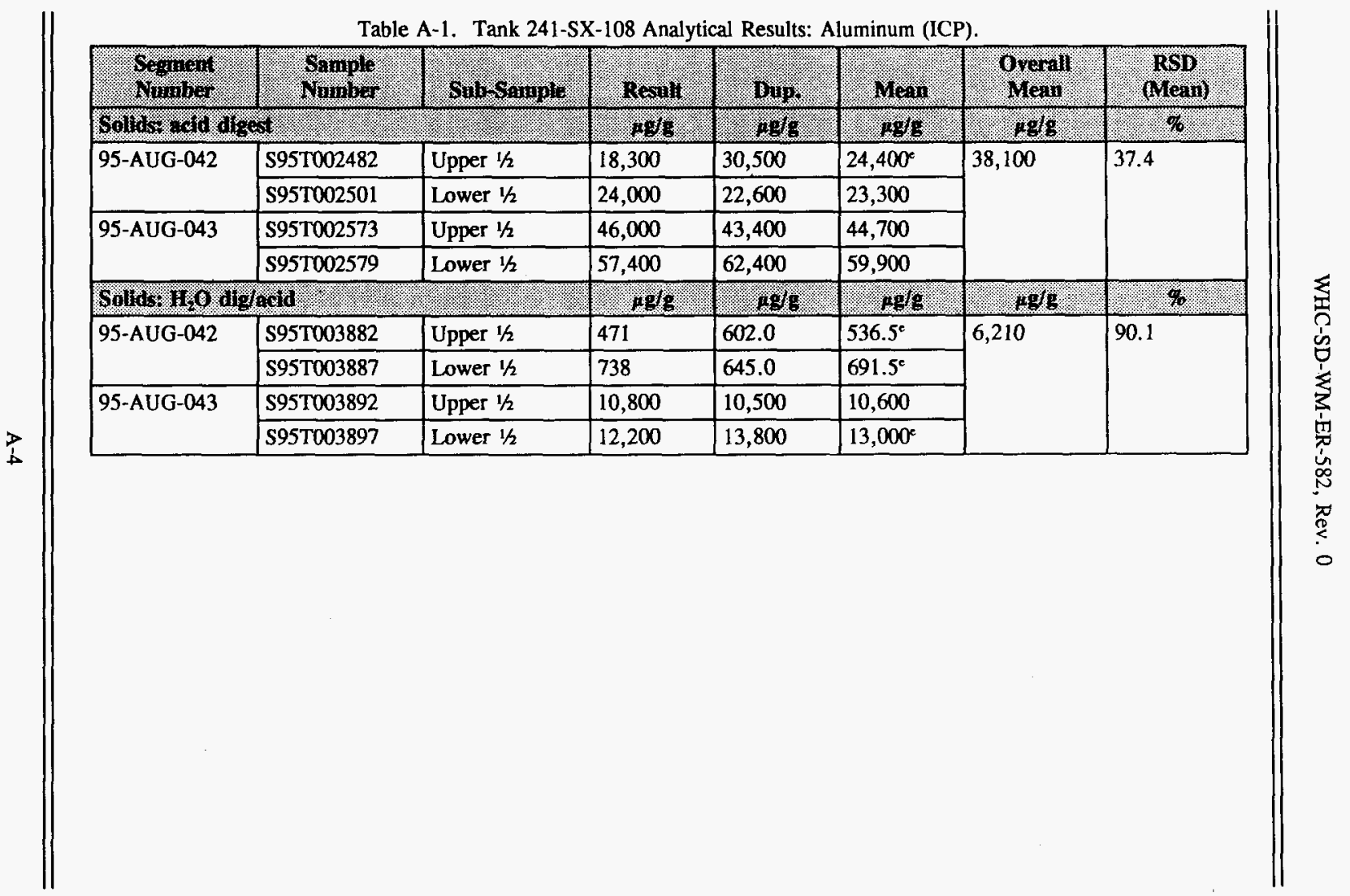


Table A-2. Tank 241-SX-108 Analytical Results: Antimony (ICP).

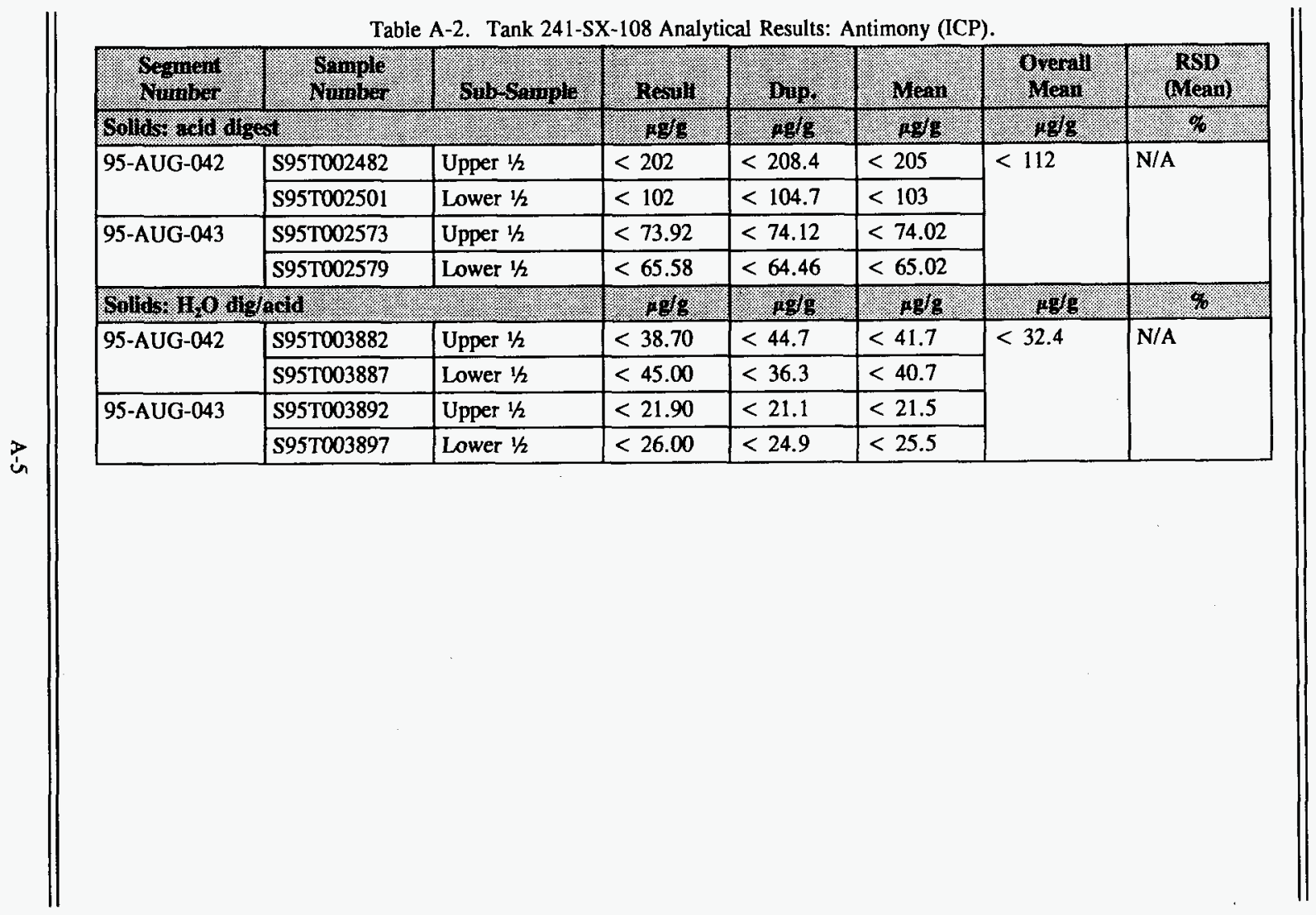




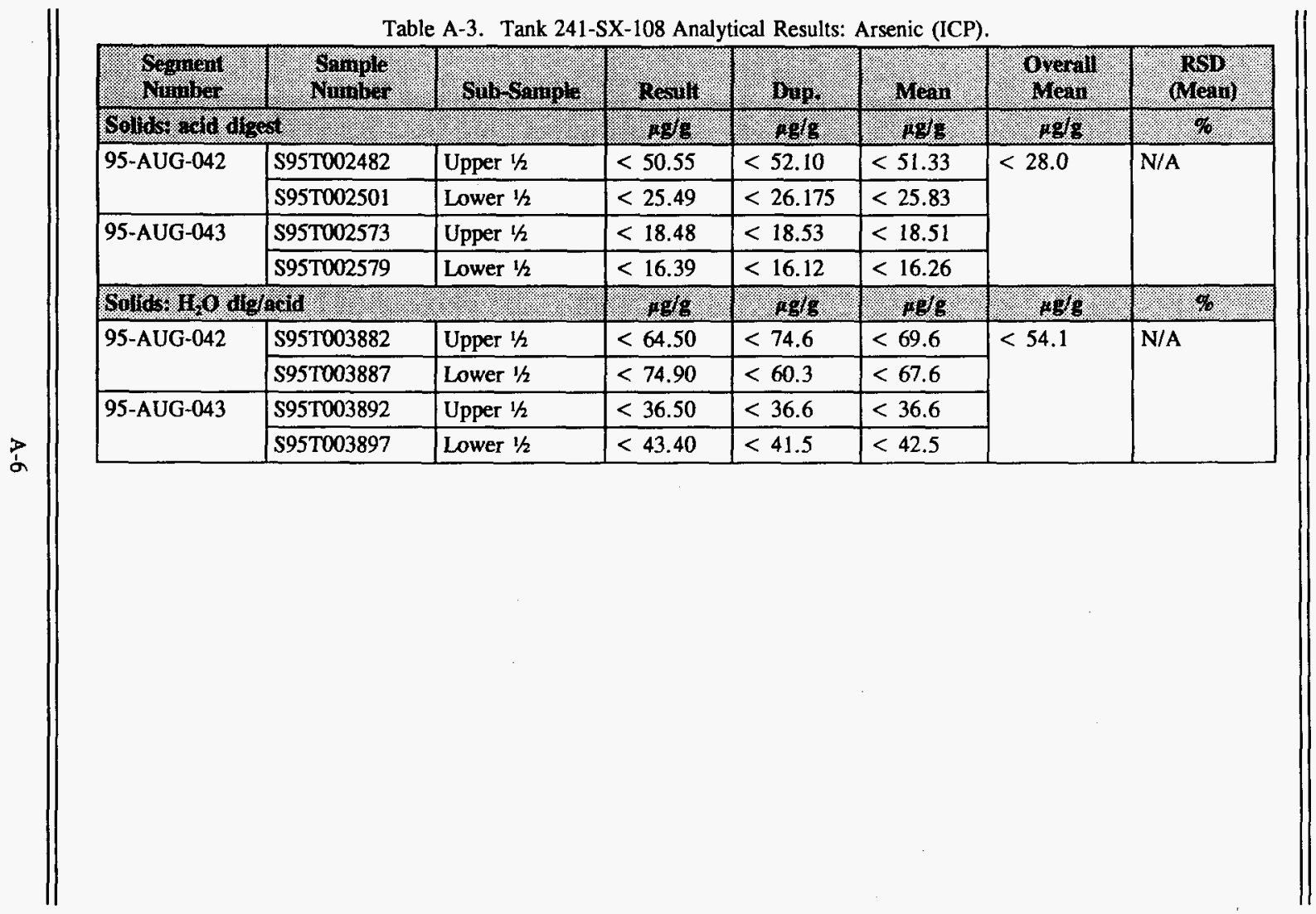




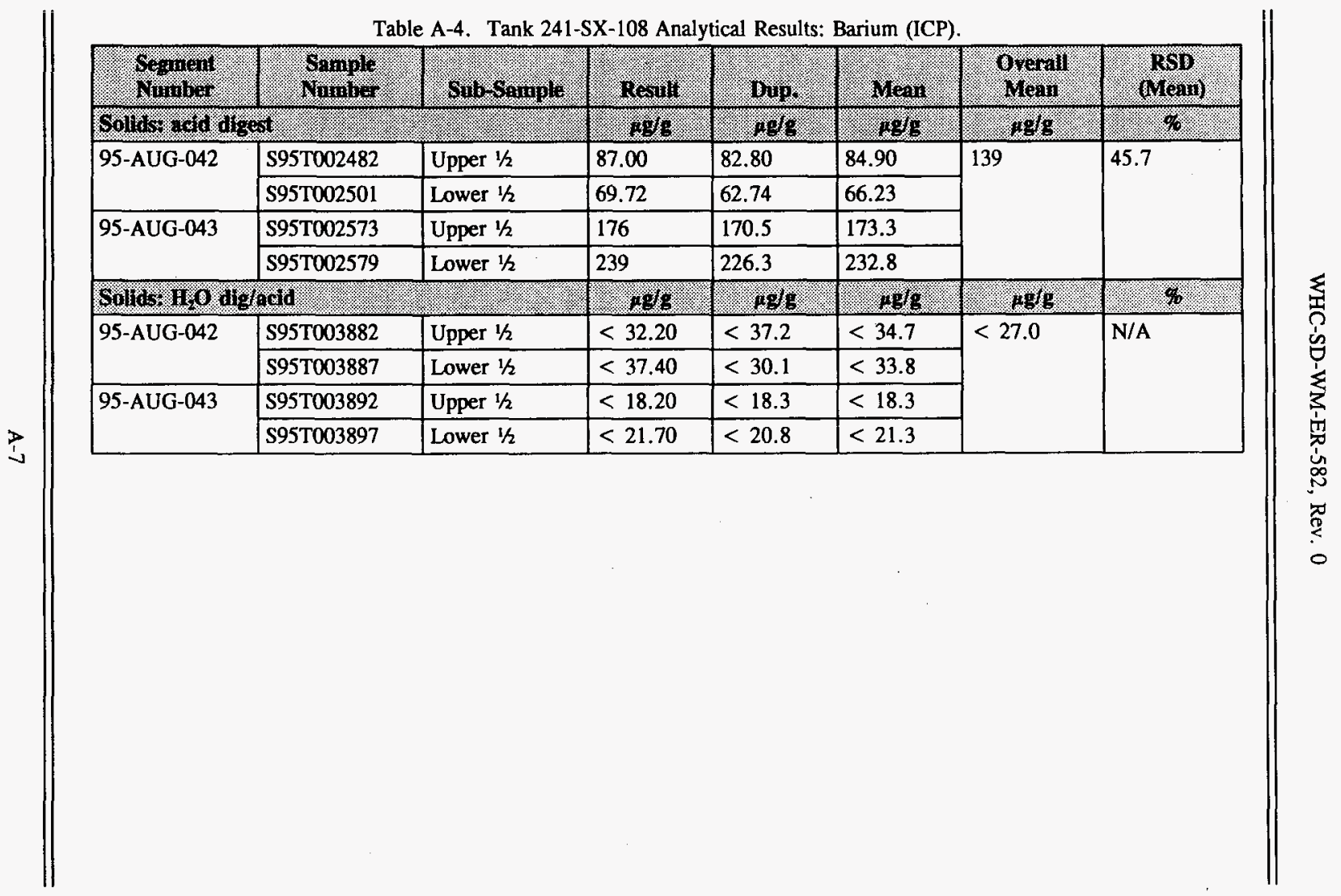


Table A-5. Tank 241-SX-108 Analytical Results: Beryllium (ICP).

\begin{tabular}{|c|c|c|c|c|c|c|c|}
\hline 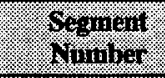 & Shmer) & Gub sinis : & 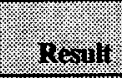 & Bup & $\operatorname{login}:$ & $\begin{array}{l}\text { Ororal } \\
\text { Meari }\end{array}$ & (1) \\
\hline \multicolumn{3}{|c|}{ Sollow wa alger } & sig/8 & (x) & 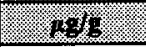 & .498 & 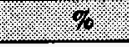 \\
\hline \multirow[t]{2}{*}{ 95-AUG-042 } & S95T002482 & Upper $1 / 2$ & $<5.055$ & $<5.210$ & $<5.133$ & \multirow[t]{4}{*}{$<2.80$} & \multirow[t]{4}{*}{ N/A } \\
\hline & \$95T002501 & Lower $1 / 2$ & $<2.549$ & $<2.618$ & $<2.584$ & & \\
\hline \multirow[t]{2}{*}{ 95-AUG-043 } & S95T002573 & Upper $1 / 2$ & $<1.848$ & $<1.853$ & $<1.851$ & & \\
\hline & \$95T002579 & Lower $1 / 2$ & $<1.639$ & $<1.612$ & $<1.626$ & & \\
\hline \multicolumn{3}{|c|}{ Sollos a o o wh fold } & 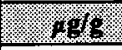 & .919 & (2) & 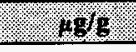 & .8 \\
\hline \multirow[t]{2}{*}{ 95-AUG-042 } & S95T003882 & Upper $1 / 2$ & $<3.220$ & $<3.72$ & $<3.47$ & \multirow[t]{4}{*}{$<2.70$} & \multirow[t]{4}{*}{ N/A } \\
\hline & S95T003887 & Lower $1 / 2$ & $<3.740$ & $<3.01$ & $<3.38$ & & \\
\hline \multirow[t]{2}{*}{ 95-AUG-043 } & \$95T003892 & Upper $1 / 2$ & $<1.820$ & $<1.83$ & $<1.83$ & & \\
\hline & S95T003897 & Lower $1 / 2$ & $<2.170$ & $<2.08$ & $<2.13$ & & \\
\hline
\end{tabular}


Table A-6. Tank 241-SX-108 Analytical Results: Bismuth (ICP).

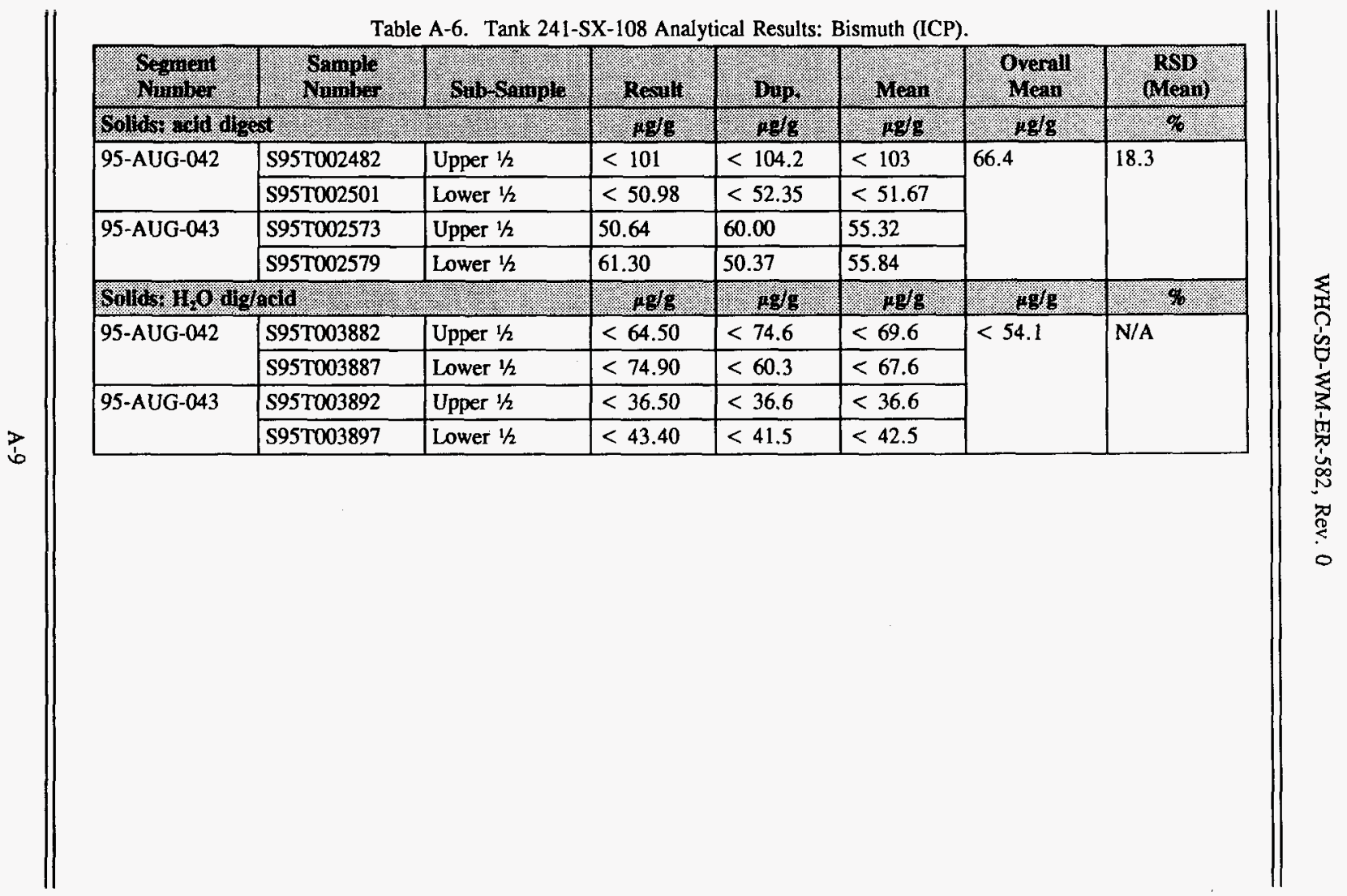




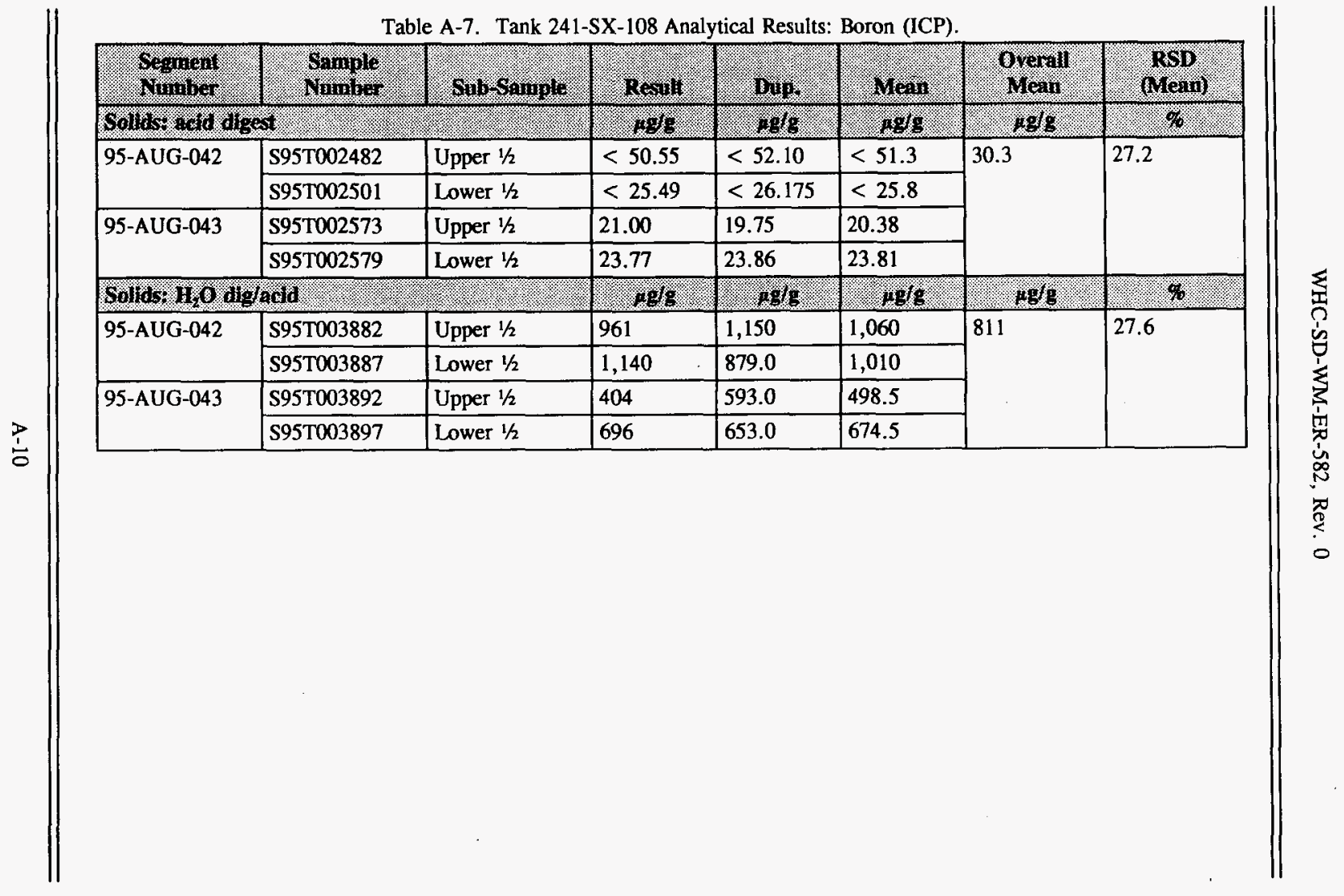




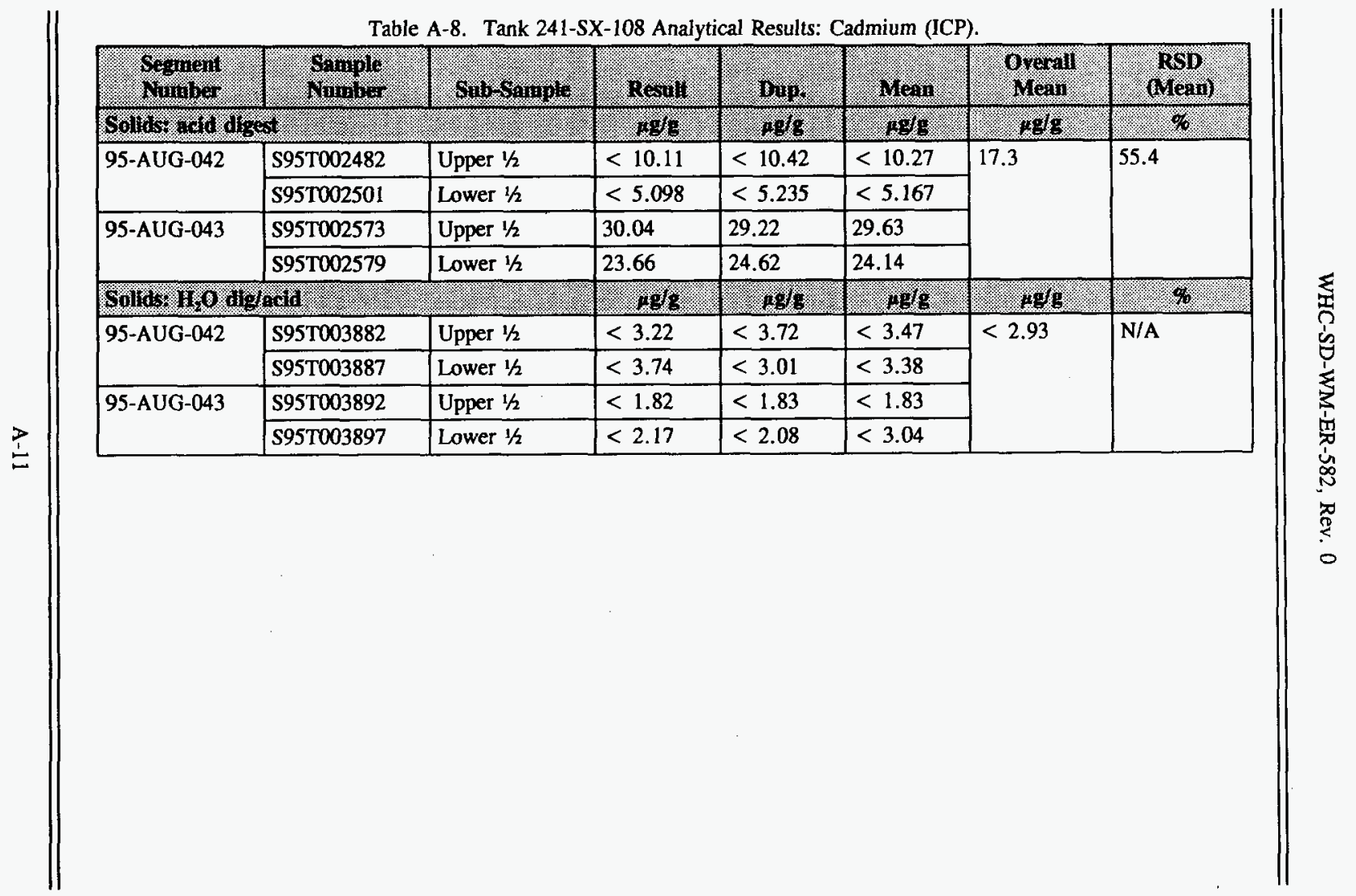




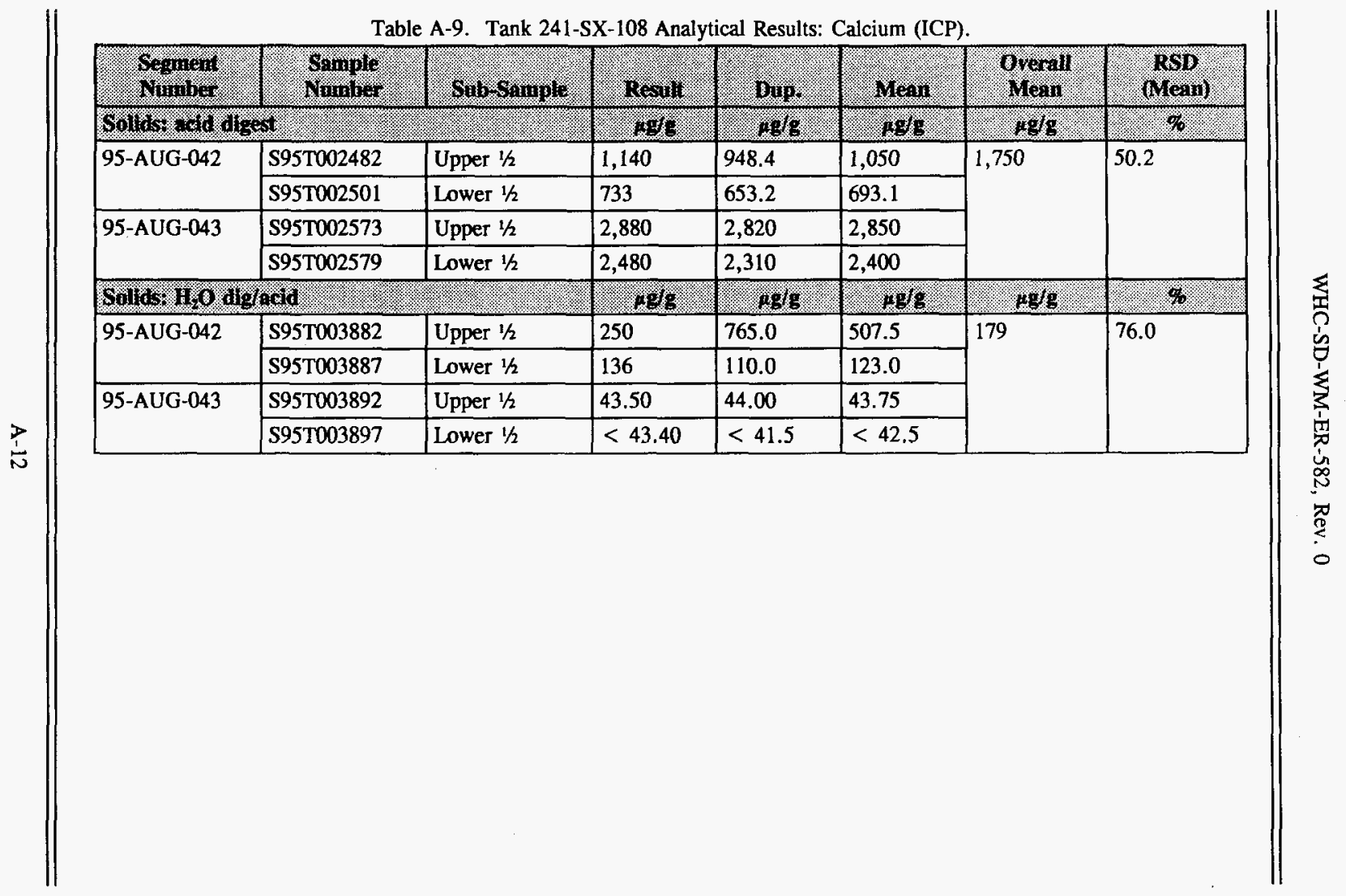




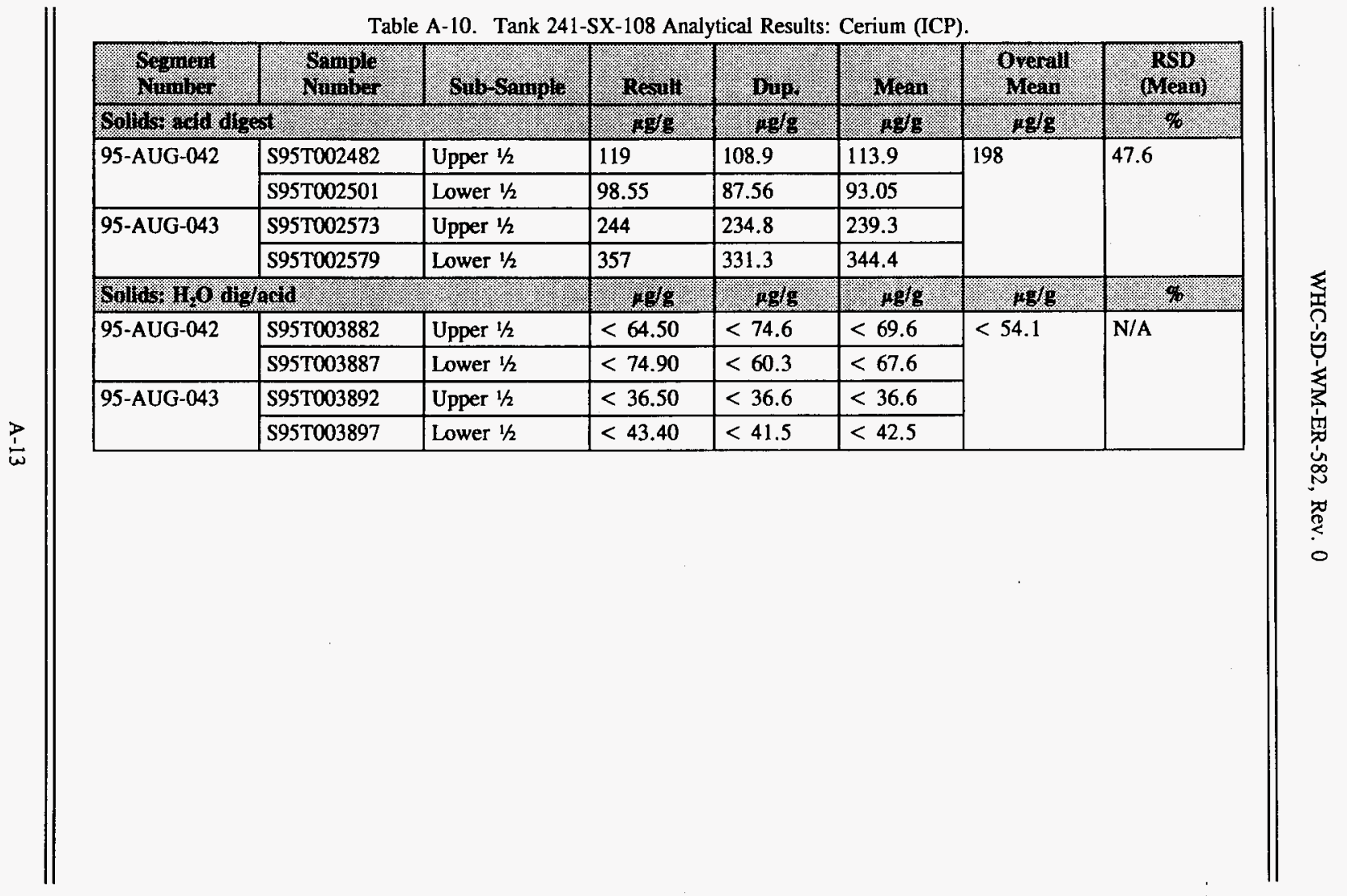


Table A-11. Tank 241-SX-108 Analytical Results: Chromium (ICP).

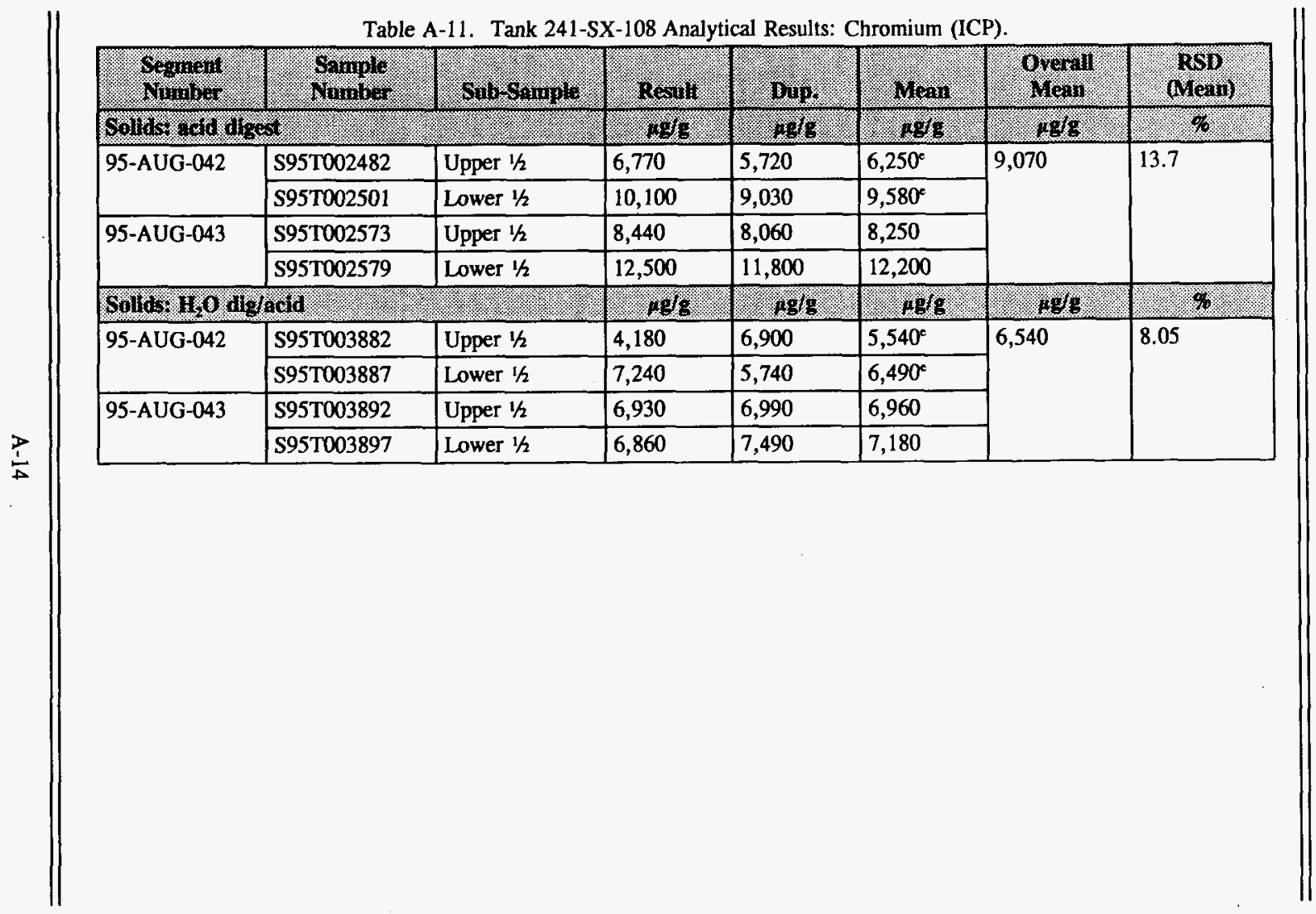




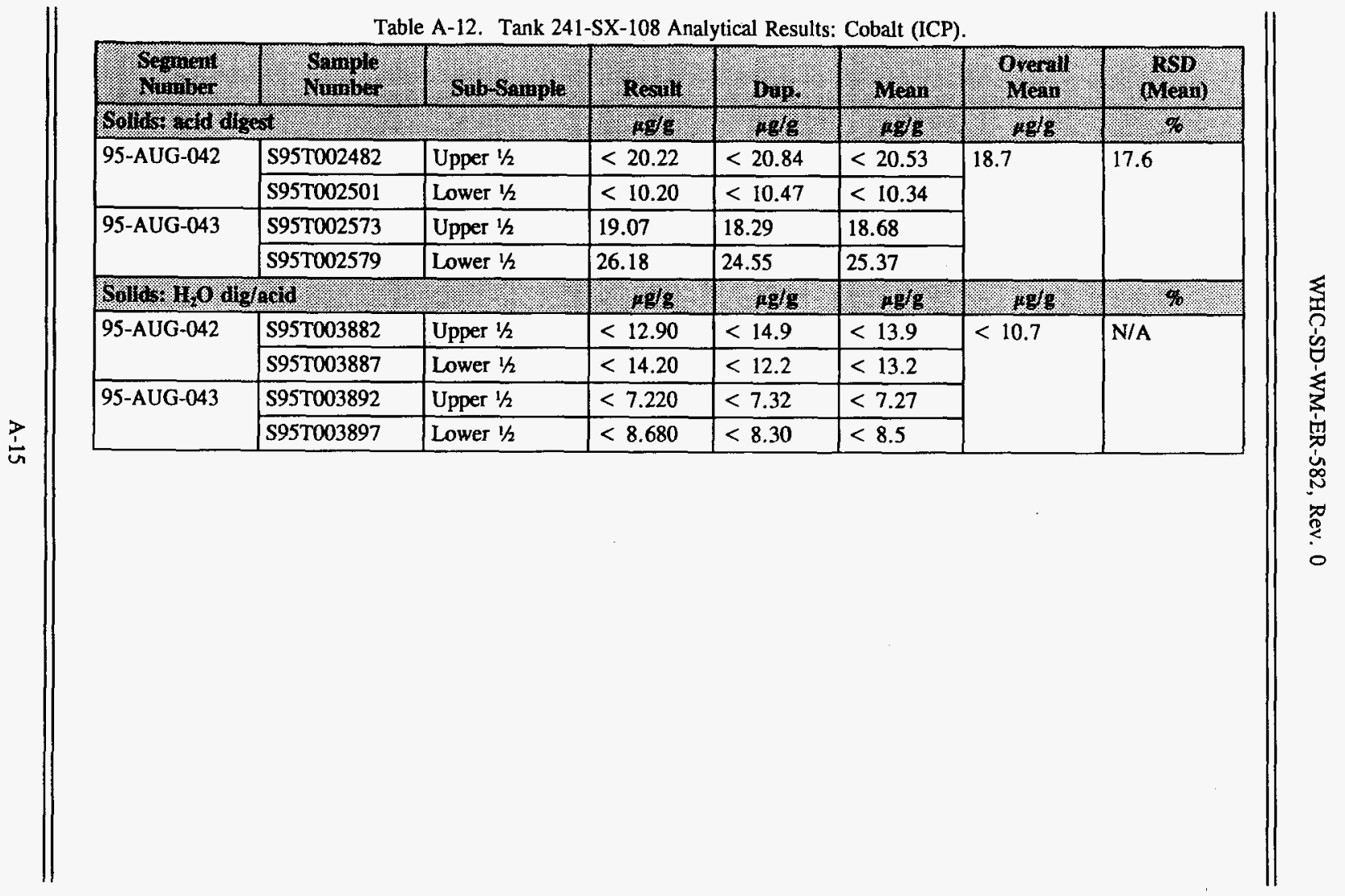







Table A-14. Tank 241-SX-108 Analytical Results: Iron (ICP).

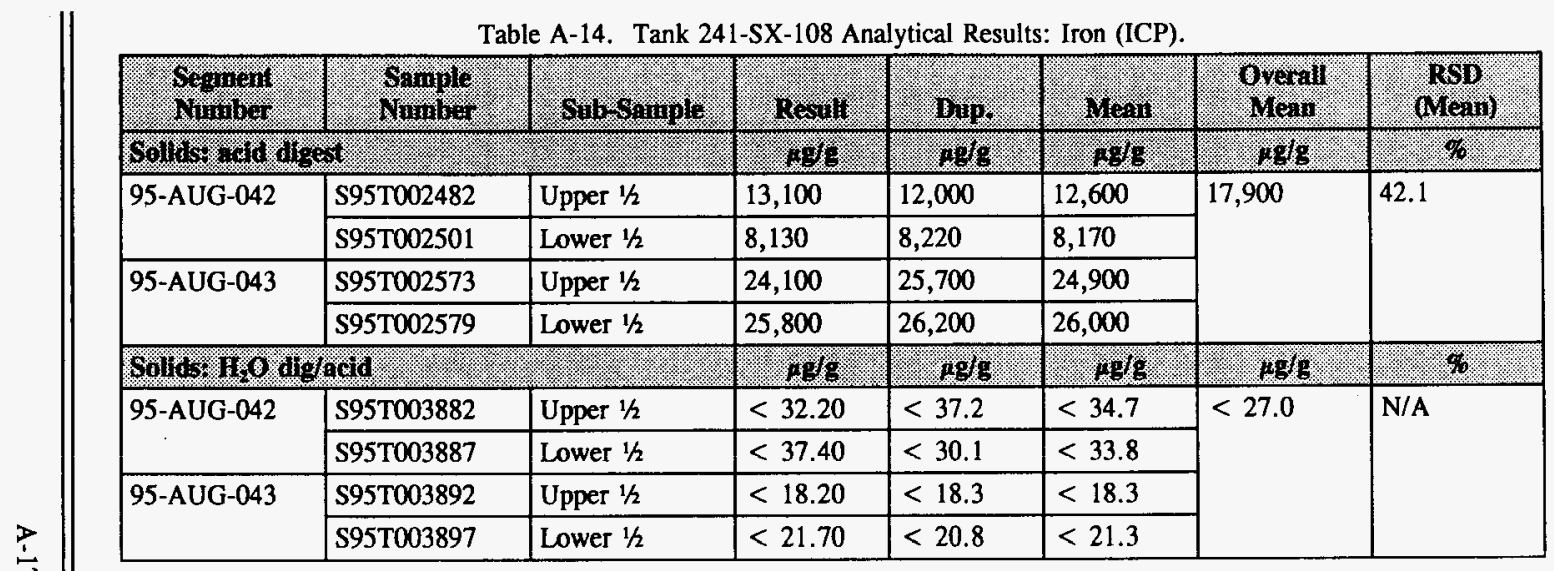




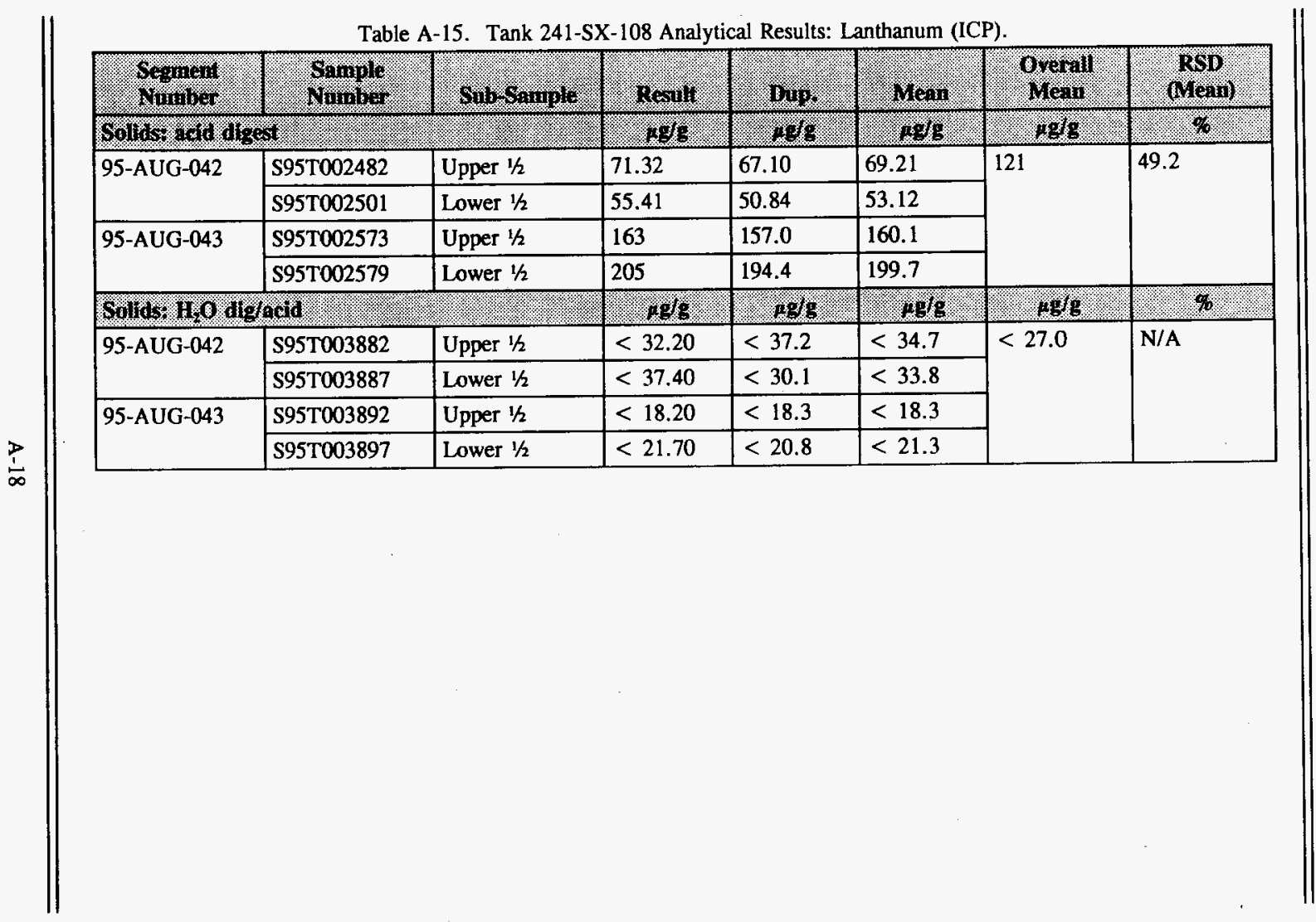


WHC-SD-WM-ER-582, Rev. 0

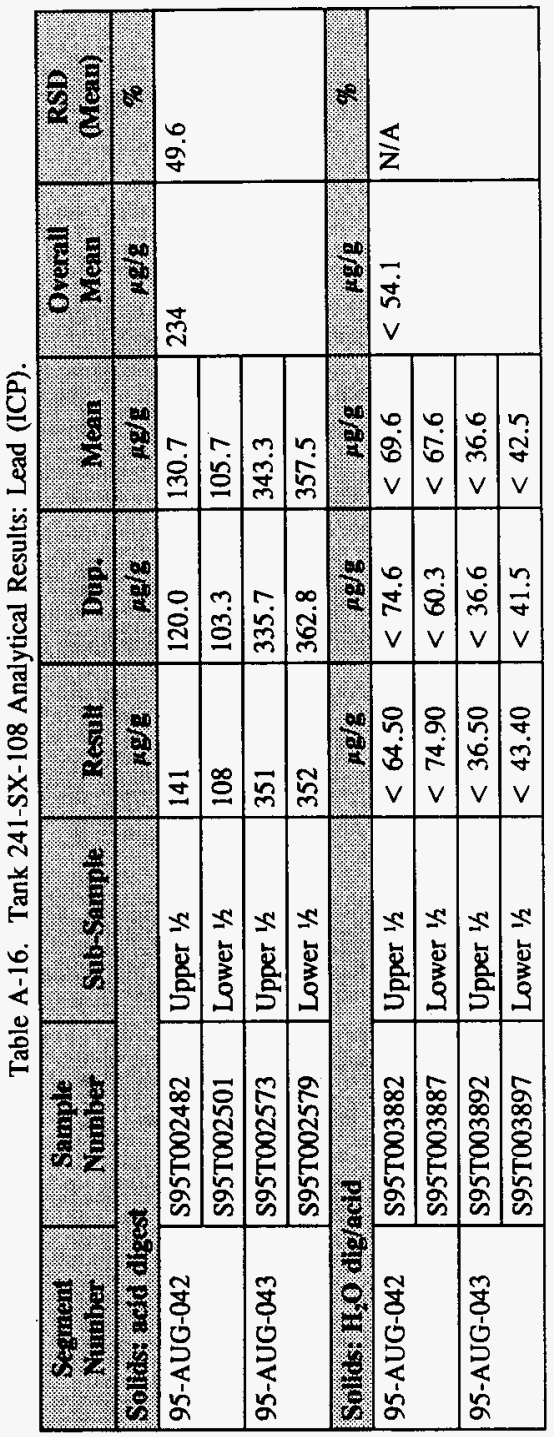




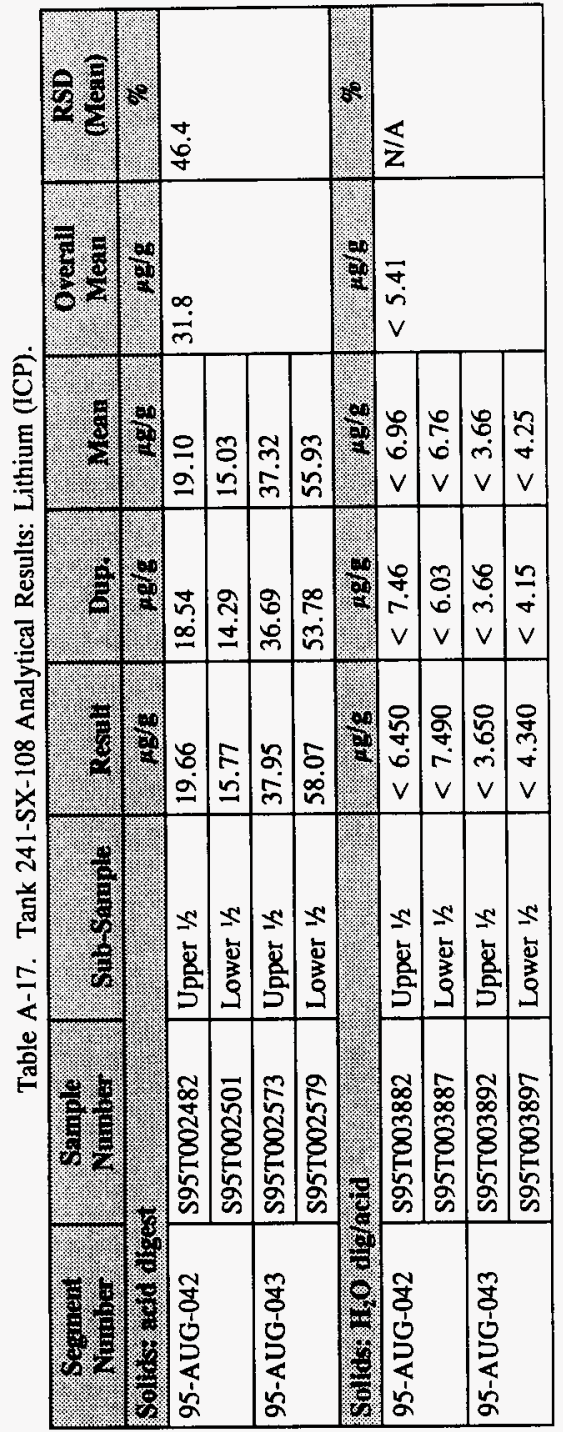




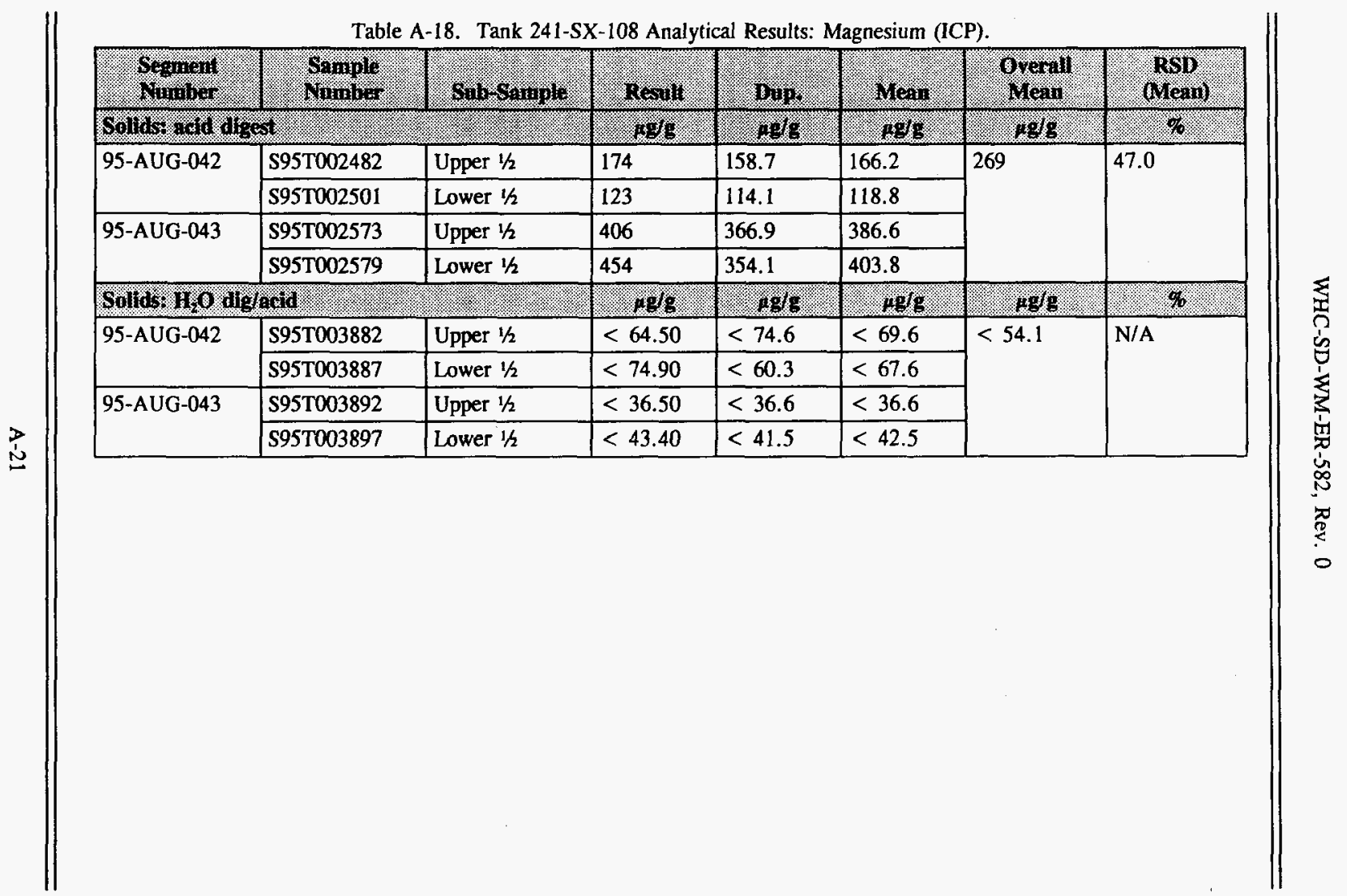


Table A-19. Tank 241-SX-108 Analytical Results: Manganese (ICP).

\begin{tabular}{|c|c|c|c|c|c|c|c|}
\hline 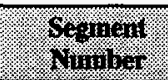 & Sampla & 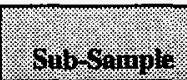 & arevili & Bup. & Men & Orerail & (1010) \\
\hline \multicolumn{3}{|c|}{ Solis indo dilsert. } & 6896 & 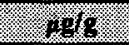 & gogs & 1989 & 28. \\
\hline \multirow[t]{2}{*}{ 95-AUG-042 } & S95T002482 & Upper $1 / 2$ & 3,530 & 3,290 & 3,410 & \multirow[t]{4}{*}{5,990} & \multirow[t]{4}{*}{49.3} \\
\hline & S95T002501 & Lower $1 / 2$ & 2,780 & 2,530 & 2,650 & & \\
\hline \multirow[t]{2}{*}{ 95-AUG-043 } & S95T002573 & Upper $1 / 2$ & 7,310 & 7,050 & 7,180 & & \\
\hline & S95T002579 & Lower $1 / 2$ & 11,000 & 10,400 & 10,700 & & \\
\hline \multicolumn{3}{|c|}{ 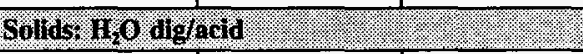 } & $8 g$ & 98 & osts & $48 / 8$ & 8. \\
\hline \multirow[t]{2}{*}{ 95-AUG-042 } & S95T003882 & Upper $1 / 2$ & $<6.450$ & $<7.46$ & $<6.96$ & \multirow[t]{4}{*}{$<5.41$} & \multirow[t]{4}{*}{$N / A$} \\
\hline & S95T003887 & Lower $1 / 2$ & $<7.490$ & $<6.03$ & $<6.76$ & & \\
\hline \multirow[t]{2}{*}{ 95-AUG-043 } & S95T003892 & Upper $1 / 2$ & $<3.650$ & $<3.66$ & $<3.66$ & & \\
\hline & S95T003897 & Lower $1 / 2$ & $<4.340$ & $<4.15$ & $<4.25$ & & \\
\hline
\end{tabular}


Table A-20. Tank 241-SX-108 Analytical Results: Molybdenum (ICP).

\begin{tabular}{|c|c|c|c|c|c|c|c|}
\hline $\begin{array}{l}\text { Segment } \\
\text { Niminger }\end{array}$ & $\begin{array}{l}\text { Sarmple } \\
\text { Number }\end{array}$ & Subsarople & Iresill: & Bups: & Mrear & $\begin{array}{l}\text { Oeverall } \\
\text { Meanil }\end{array}$ & $\begin{array}{l}\text { RSD } \\
\text { (Mean) }\end{array}$ \\
\hline \multicolumn{2}{|c|}{ Solkt acd digest } & (1) & 1.08 & $=0 \mathrm{glg}$ & $\sqrt{16 / 5}$ & .189 & 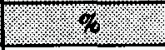 \\
\hline \multirow[t]{2}{*}{ 95-AUG-042 } & S95T002482 & Upper $1 / 2$ & $<50.55$ & $<52.10$ & $<51.3$ & \multirow[t]{4}{*}{34} & \multirow[t]{4}{*}{19.0} \\
\hline & S95T002501 & Lower $1 / 2$ & $<25.49$ & $<26.175$ & $<25.83$ & & \\
\hline \multirow[t]{2}{*}{ 95-AUG-043 } & S95T002573 & Upper $1 / 2$ & 24.34 & 21.14 & 22.74 & & \\
\hline & S95T002579 & Lower $1 / 2$ & 40.61 & 31.42 & 36.01 & & \\
\hline \multicolumn{2}{|c|}{ Solds H.O diglacd } & 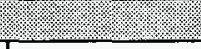 & $1.48 \mathrm{~g}$ & $198 \mathrm{~g}$ & 1.3918 & $.9 \mathrm{gg}$ & 1.9. \\
\hline \multirow[t]{2}{*}{ 95-AUG-042 } & S95T003882 & Upper $1 / 2$ & $<32.20$ & $<37.2$ & $<34.7$ & \multirow[t]{4}{*}{$<28.8$} & \multirow[t]{4}{*}{ N/A } \\
\hline & S95T003887 & Lower $1 / 2$ & $<37.40$ & $<30.1$ & $<33.8$ & & \\
\hline \multirow[t]{2}{*}{ 95-AUG-043 } & S95T003892 & Upper $1 / 2$ & 23.60 & 24.40 & 24.00 & & \\
\hline & S95T003897 & Lower $1 / 2$ & $<21.70$ & $<23.80$ & $<22.8$ & & \\
\hline
\end{tabular}




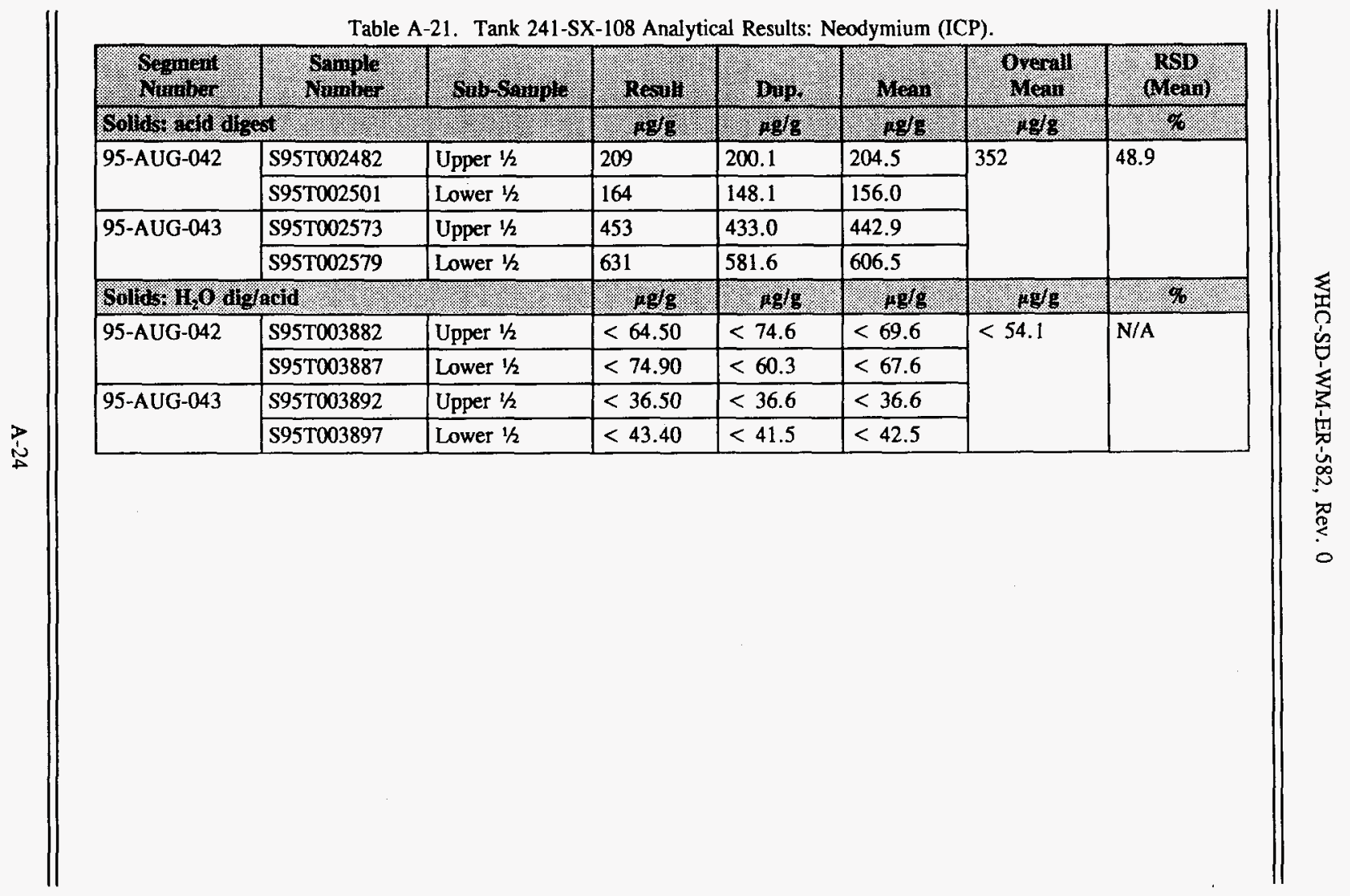




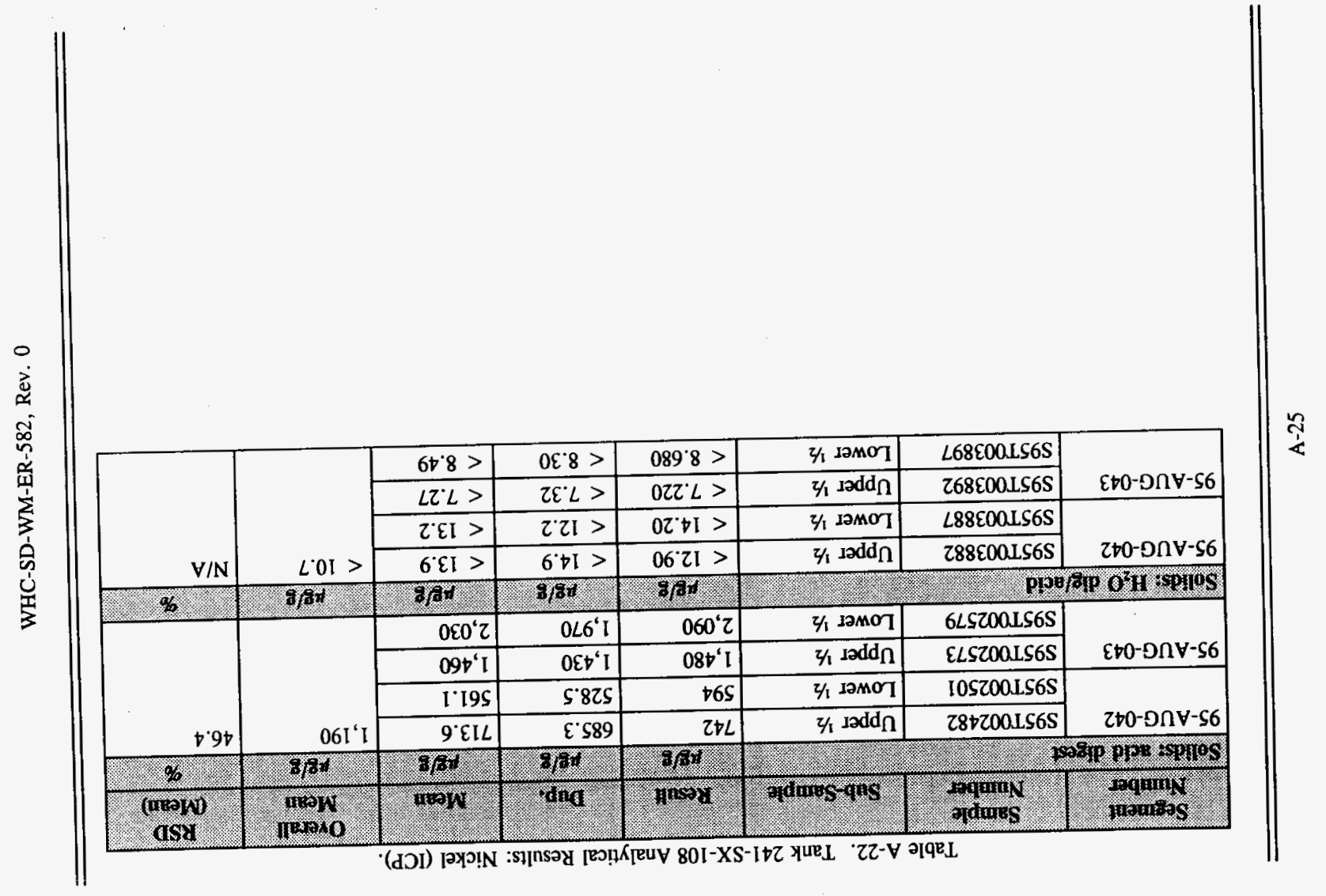


Table A-2j. Tank $241-S \bar{X}-108$ Analytical Results: Phosphorus (ICP).

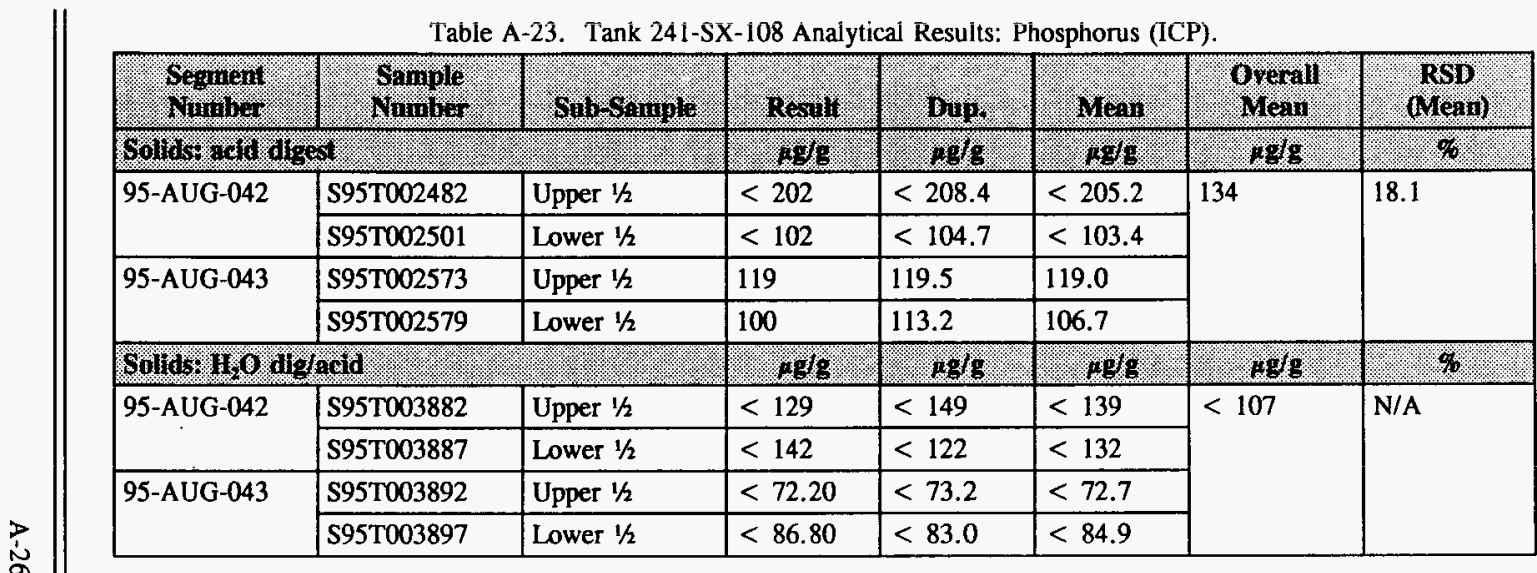


Table A-24. Tank 241-SX-108 Analytical Results: Potassium (ICP).

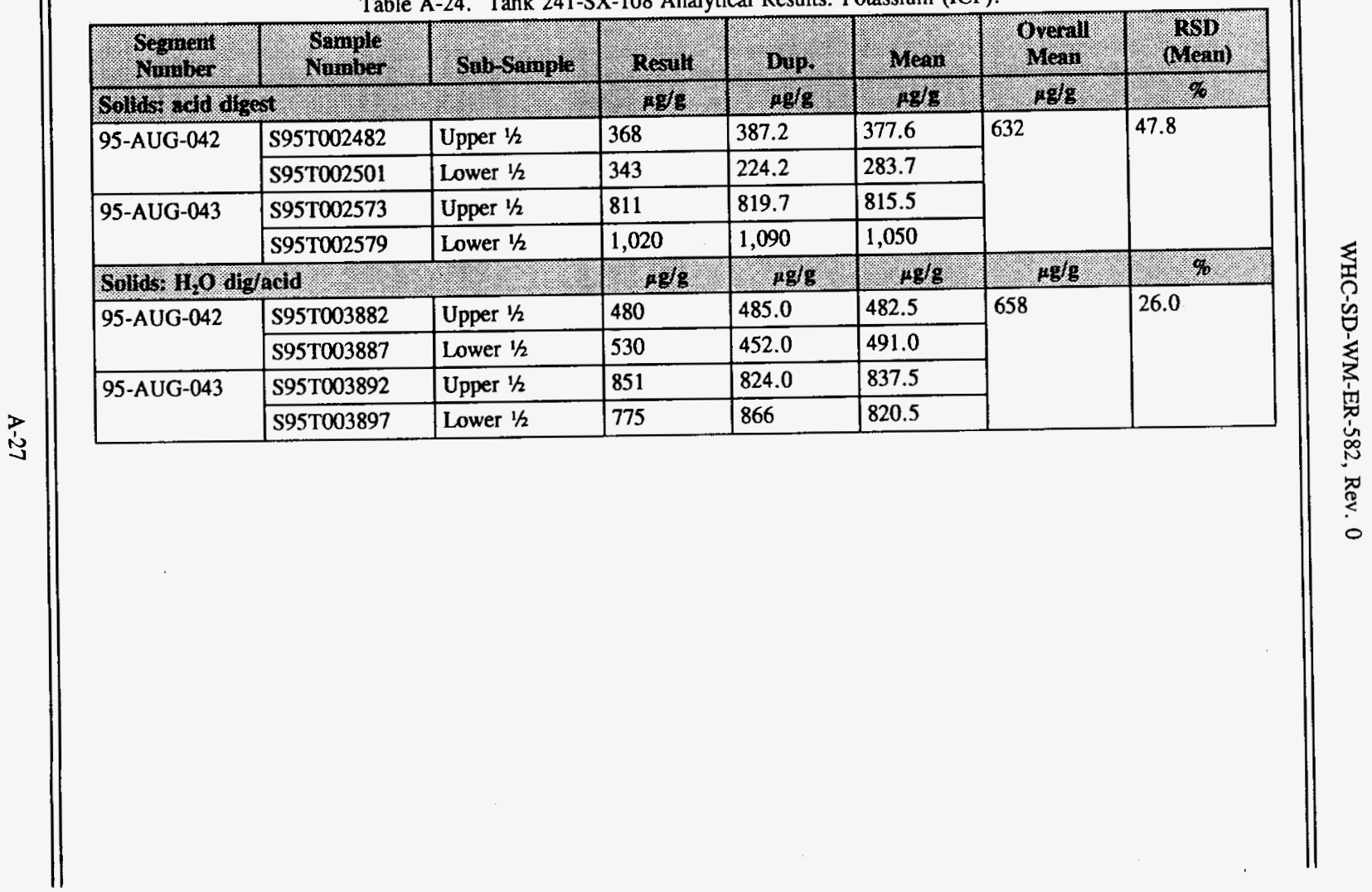




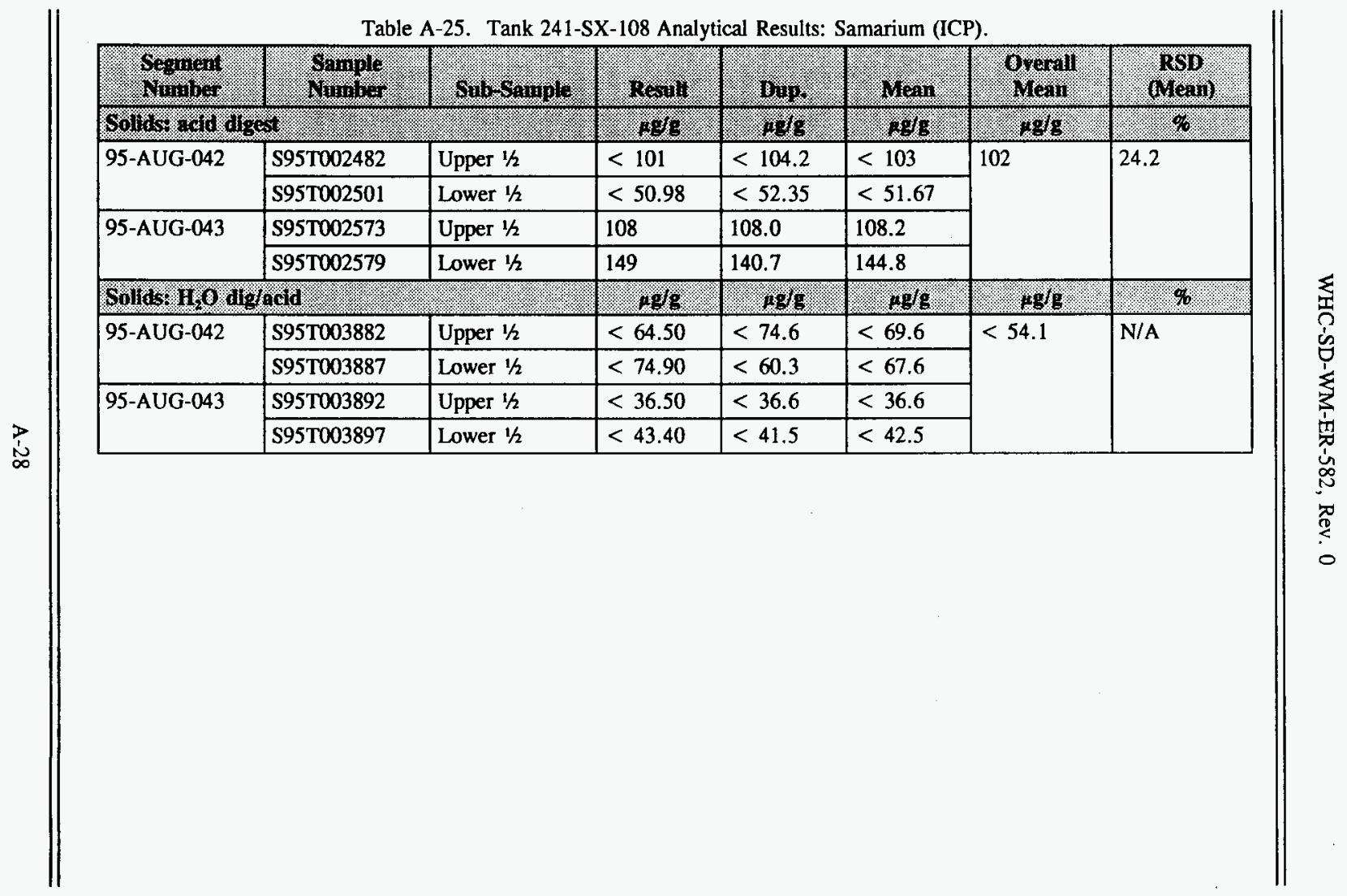




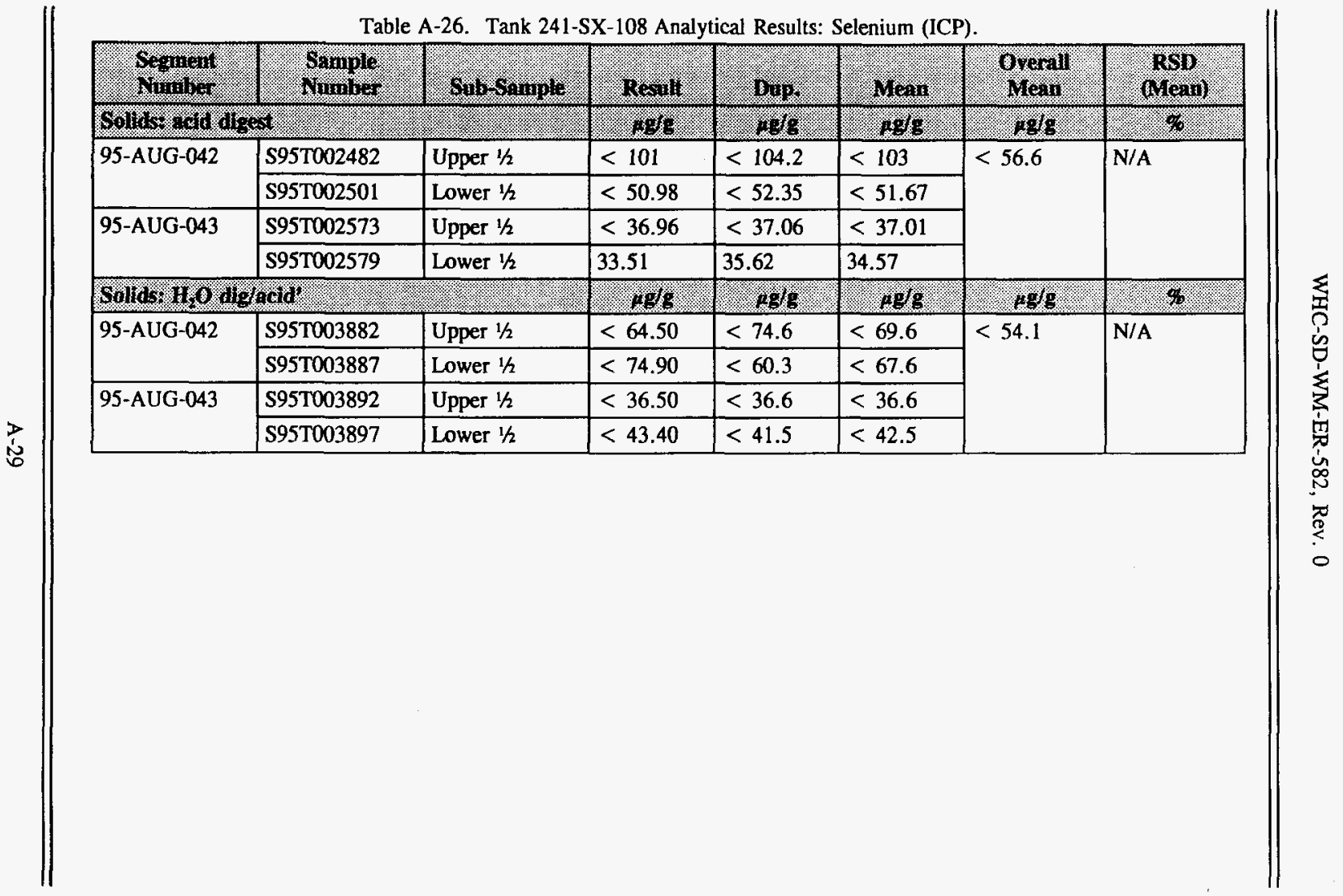




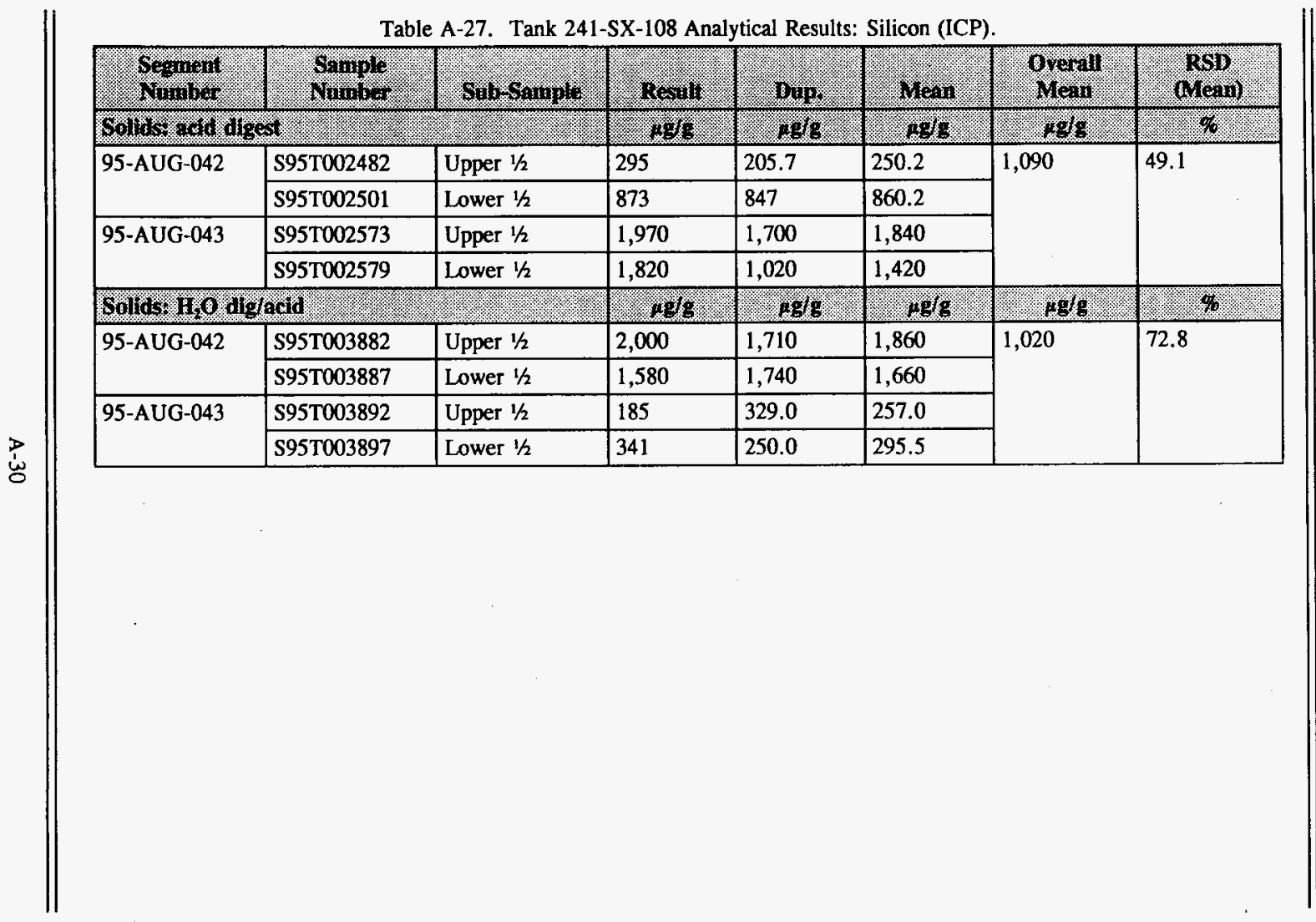




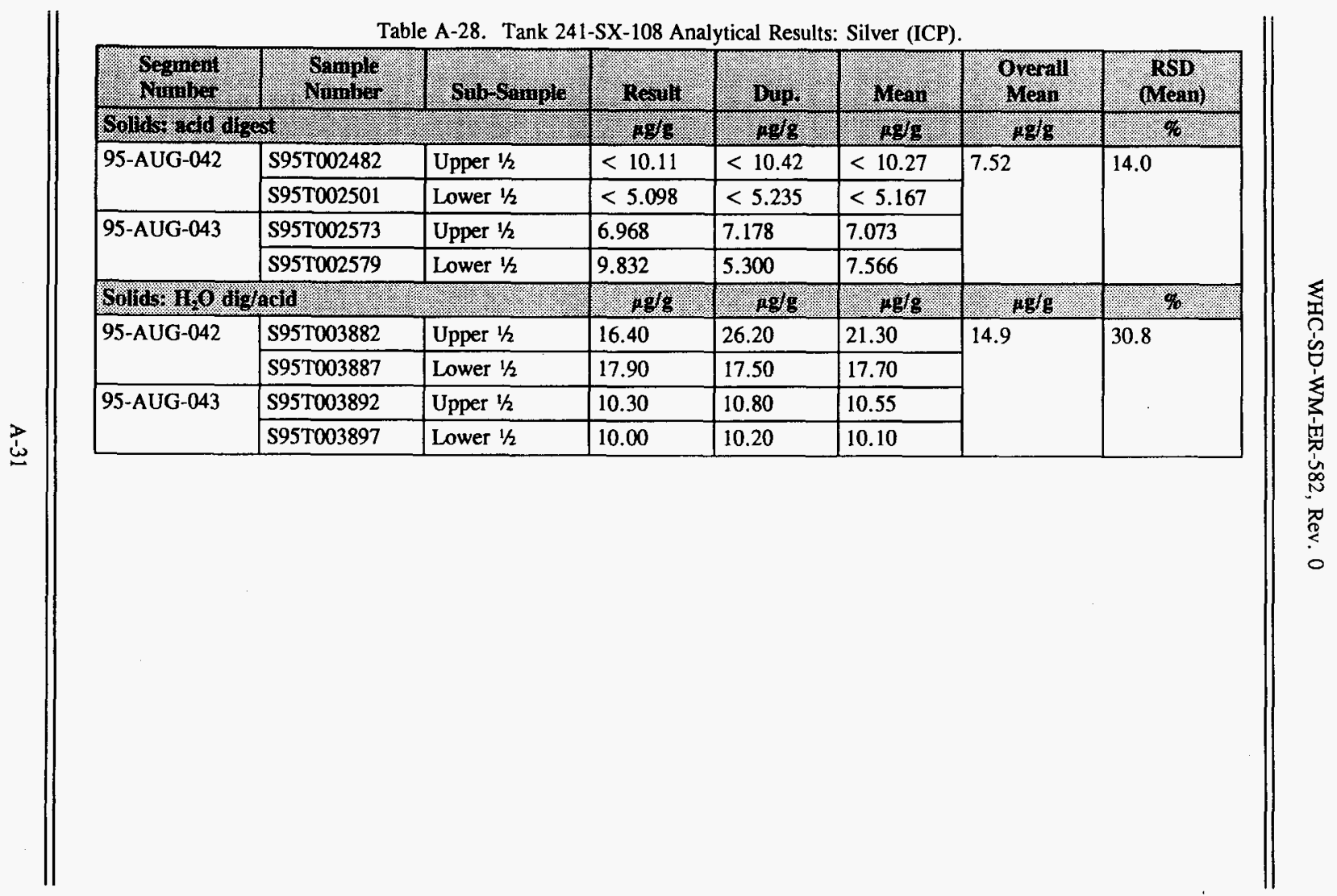




\begin{tabular}{|c|c|c|c|c|c|c|c|}
\hline $\begin{array}{l}\text { Seganent } \\
\text { rubiber }\end{array}$ & $\begin{array}{l}\text { Sumple } \\
\text { Numbe- }\end{array}$ & Subsariple & 1iesili: & vip. & Mean & $\begin{array}{l}\text { Grerail } \\
\text { Mean }\end{array}$ & $\begin{array}{l}\text { RSD } \\
\text { (Mean) }\end{array}$ \\
\hline \multicolumn{2}{|c|}{ Soliks acti aigest } & 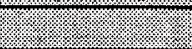 & 1898 & ogrg & 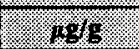 & $194 \mathrm{~g}$ & 19 \\
\hline \multirow[t]{2}{*}{ 95-AUG-042 } & S95T002482 & Upper $1 / 2$ & $2.29 \mathrm{E}+05$ & $2.29 \mathrm{E}+05$ & $2.29 \mathrm{E}+05$ & \multirow[t]{4}{*}{$1.85 E+05$} & \multirow[t]{4}{*}{17.2} \\
\hline & S95T002501 & Lower $1 / 2$ & $2.06 \mathrm{E}+05$ & $2.01 \mathrm{E}+05$ & $2.03 E+05$ & & \\
\hline \multirow[t]{2}{*}{ 95-AUG-043 } & S95T002573 & Upper $1 / 2$ & $1.66 \mathrm{E}+05$ & $1.53 \mathrm{E}+05$ & $1.60 \mathrm{E}+05$ & & \\
\hline & S95T002579 & Lower $1 / 2$ & $1.45 \mathrm{E}+05$ & $1.47 \mathrm{E}+05$ & $1.46 \mathrm{E}+05$ & & \\
\hline \multicolumn{3}{|c|}{ Sollds. $14 \mathrm{O}$ dig/ard } & $191 \mathrm{~g}$ & (2. $18 \mathrm{~g} / \mathrm{B}$. & $18 \mathrm{~g}$ & .1098 & 9 \\
\hline \multirow[t]{2}{*}{ 95-AUG-042 } & S95T003882 & Upper $1 / 2$ & $2.18 \mathrm{E}+05$ & $3.55 \mathrm{E}+05$ & $2.86 \mathrm{E}+05$ & \multirow[t]{4}{*}{$1.95 \mathrm{E}+05$} & \multirow[t]{4}{*}{36.0} \\
\hline & $595 T 003887$ & Lower $1 / 2$ & $2.45 \mathrm{E}+05$ & $2.43 \mathrm{E}+05$ & $2.44 \mathrm{E}+05$ & & \\
\hline \multirow[t]{2}{*}{ 95-AUG-043 } & S95T003892 & Upper $1 / 2$ & $1.17 \mathrm{E}+05$ & $1.26 \mathrm{E}+05$ & $1.22 \mathrm{E}+05$ & & \\
\hline & S95T003897 & Lower $1 / 2$ & $1.23 \mathrm{E}+05$ & $1.33 \mathrm{E}+05$ & $1.28 \mathrm{E}+05$ & & \\
\hline
\end{tabular}




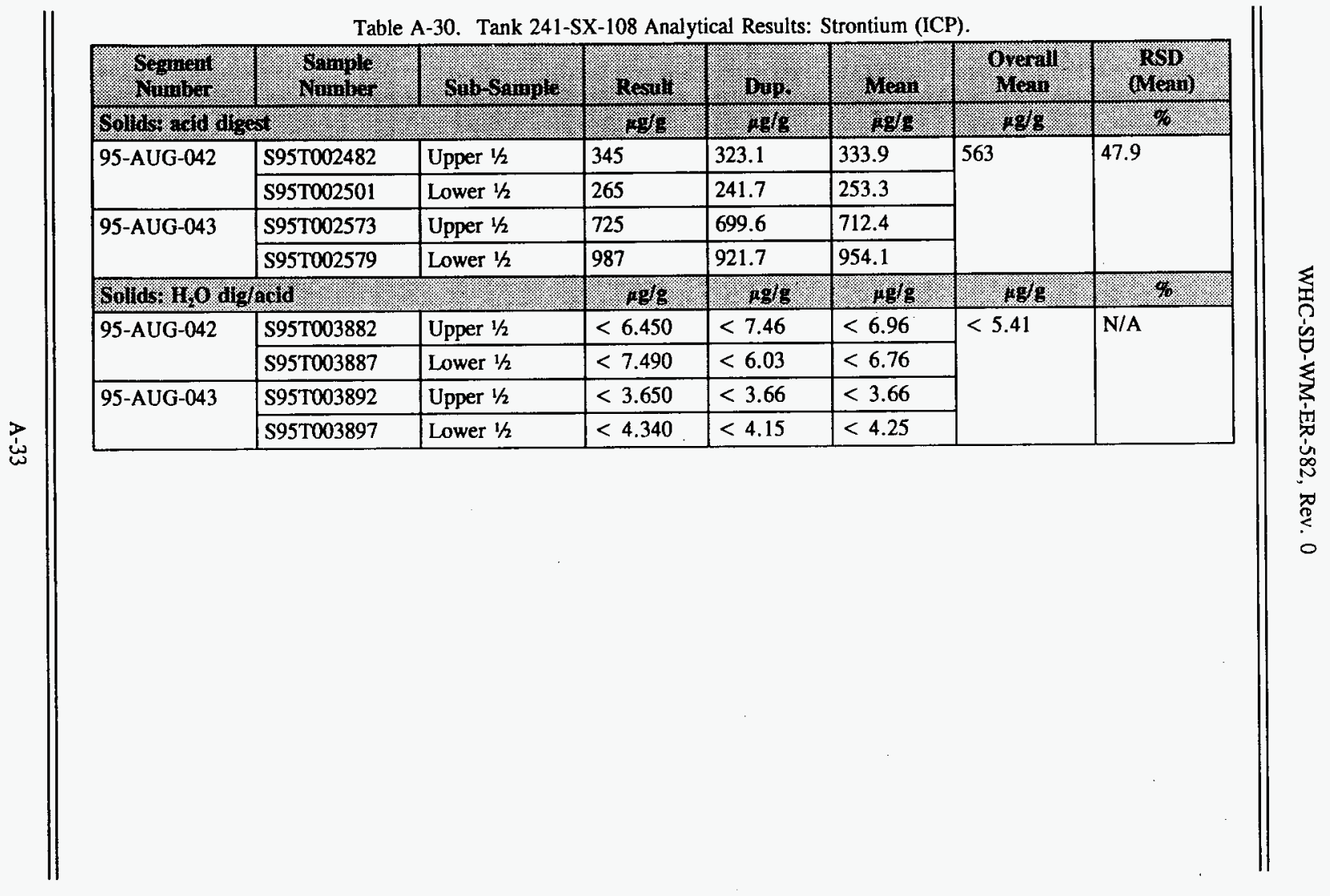




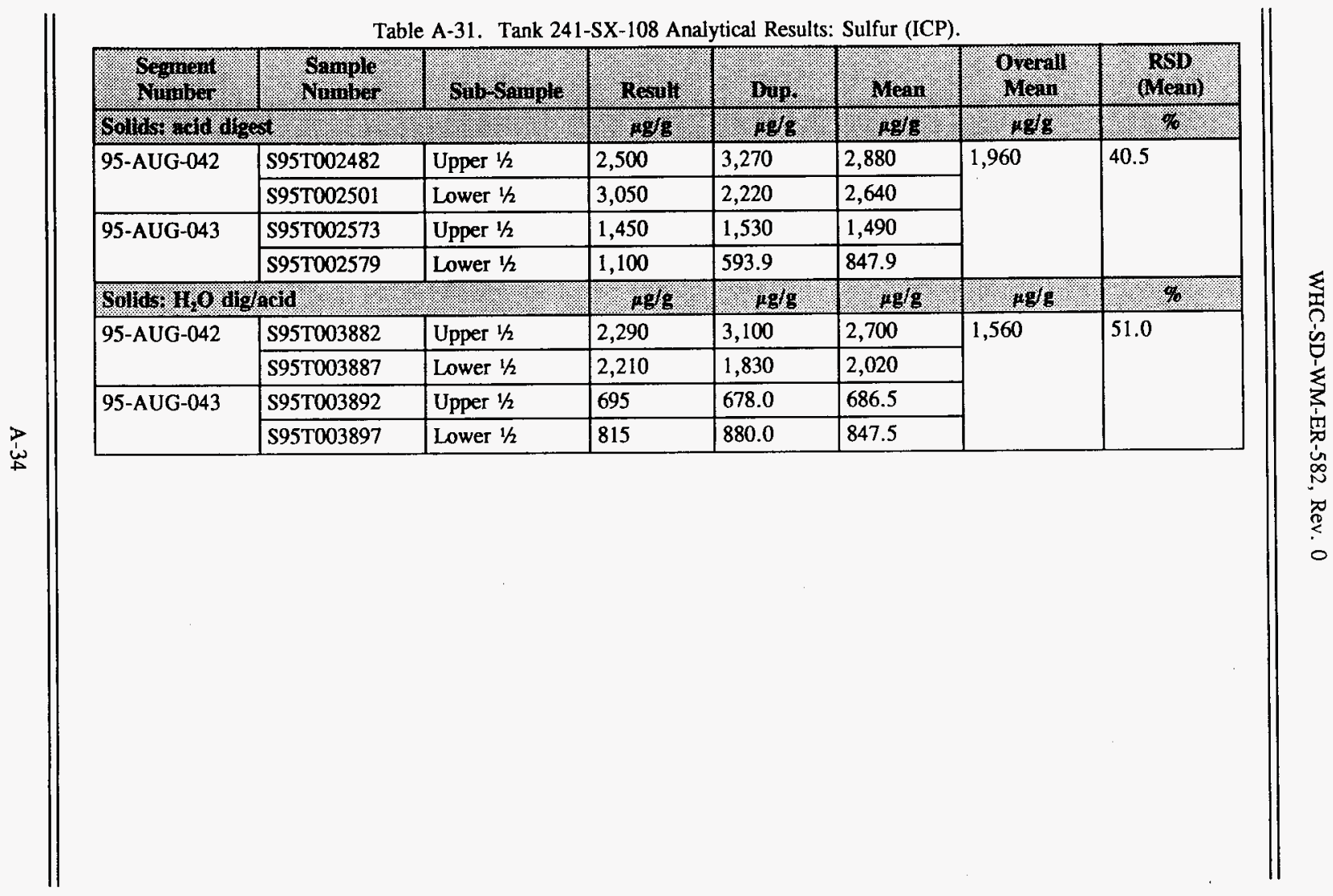




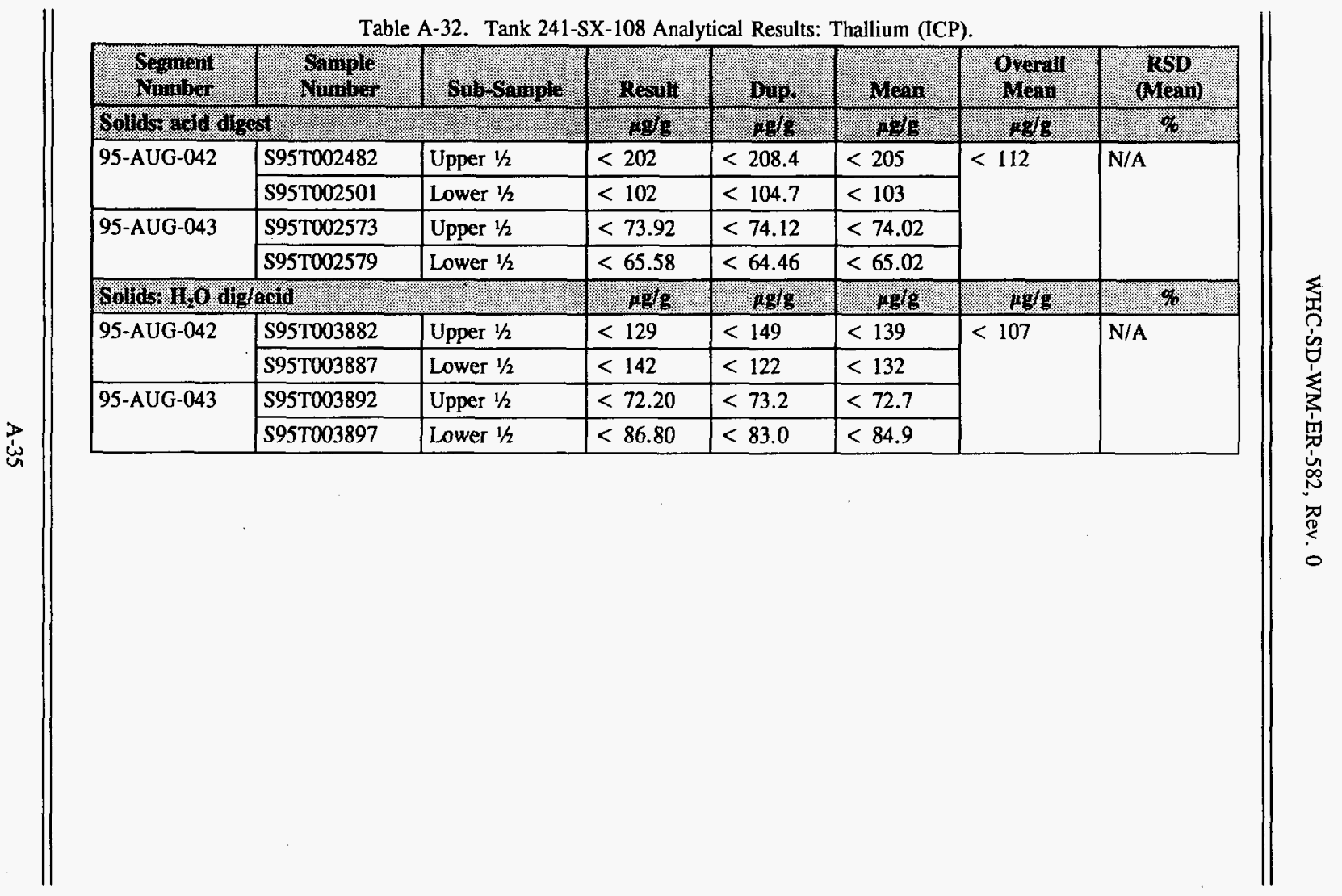




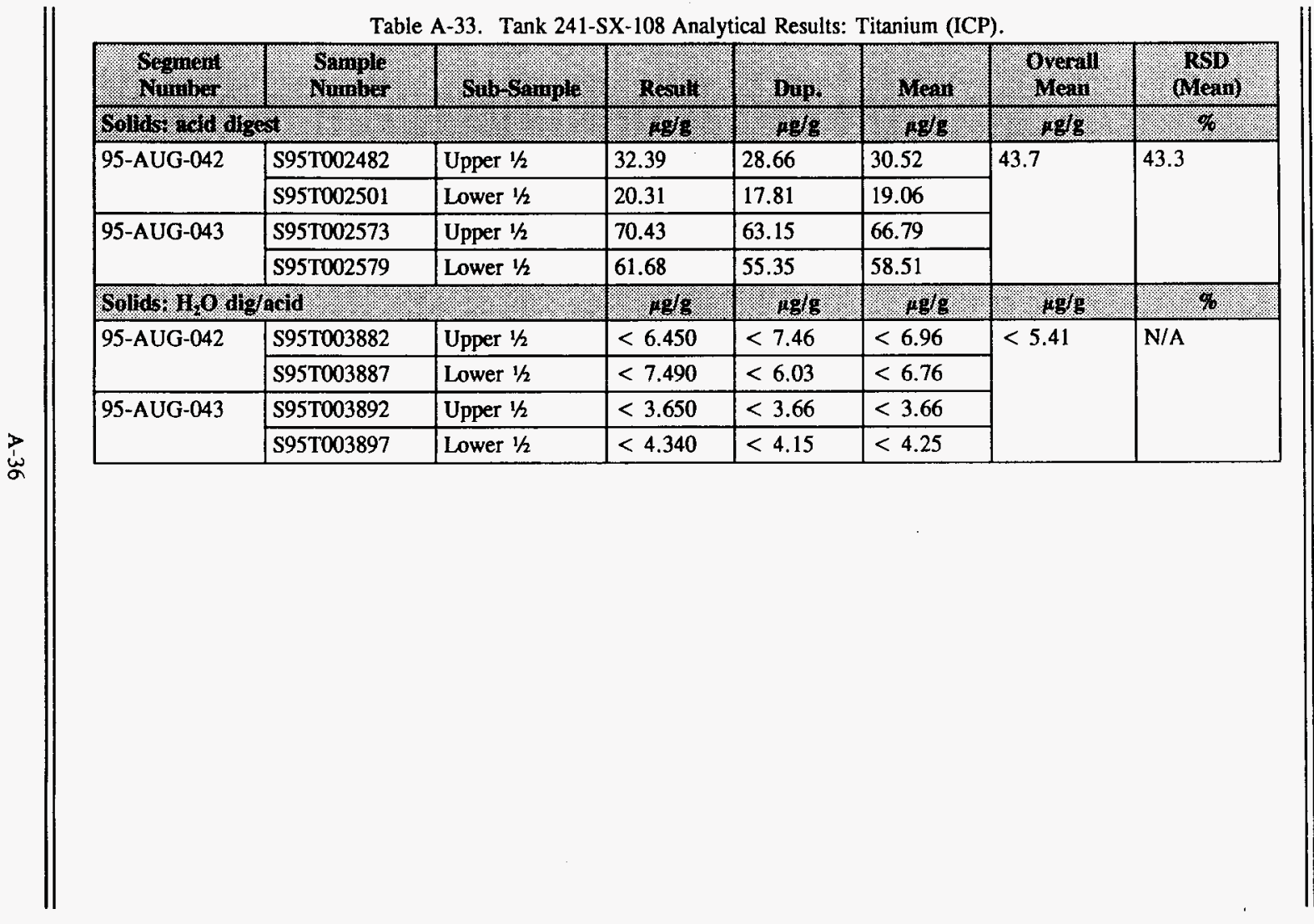




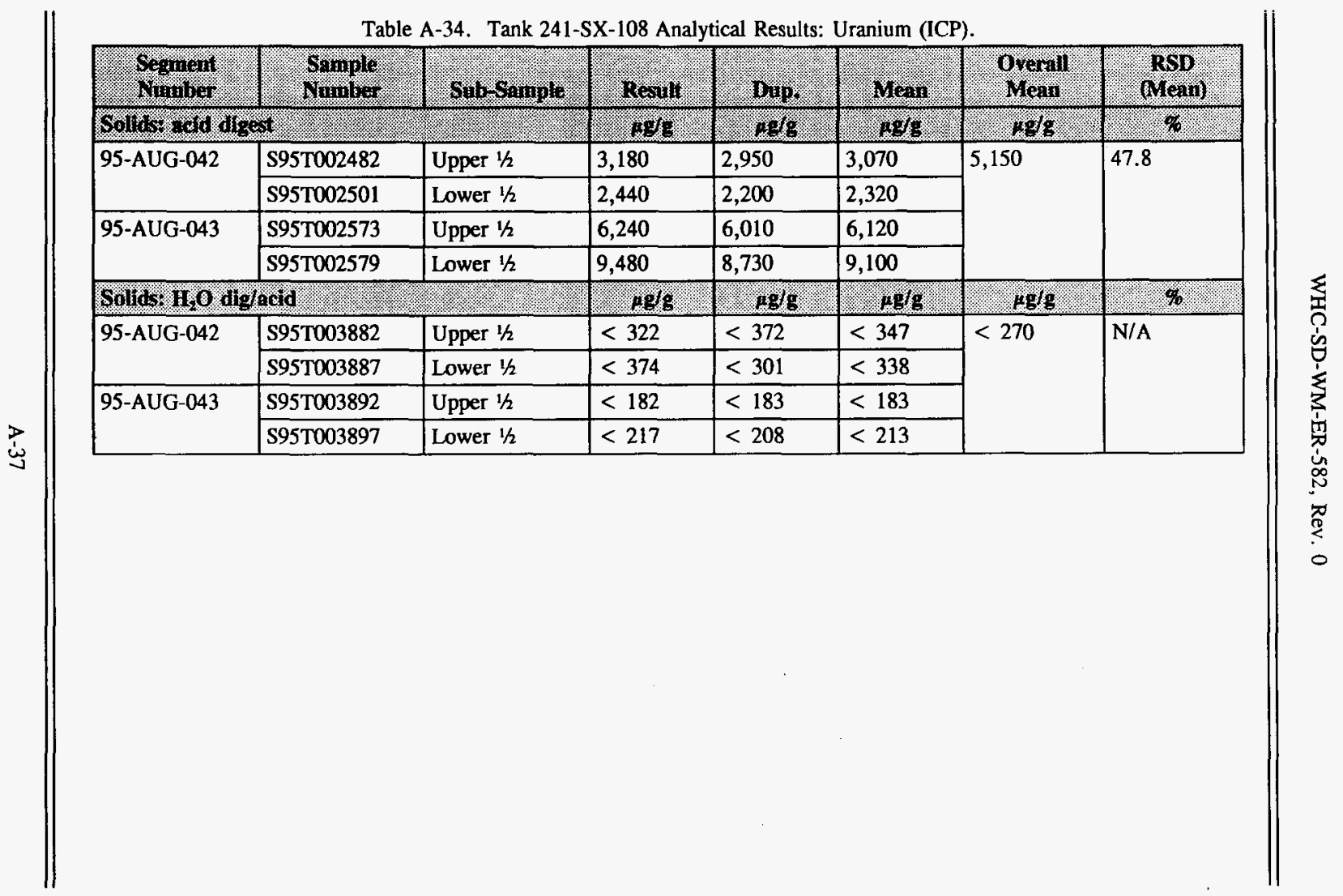


Table A-35. Tank 241-SX-108 Analytical Results: Uranium (Phosphorescence).

\begin{tabular}{|c|c|c|c|c|c|c|c|}
\hline Minemor & $\begin{array}{l}\text { sample } \\
\text { Namios }\end{array}$ & Sub sample. & Ievill & Bup & Mear & $\begin{array}{l}\text { owerill } \\
\text { wear }\end{array}$ & $\begin{array}{l}\text { RSD } \\
\text { (Mean) }\end{array}$ \\
\hline $5016 \%$ nimon & 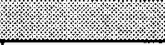 & 2 & 40 & 2018 & $.19_{8}$ & 189 & 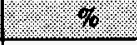 \\
\hline \multirow[t]{2}{*}{ 95-AUG-042 } & S95T003885 & Upper $1 / 2$ & 3,580 & 3,180 & 3,380 & \multirow[t]{4}{*}{7,540} & \multirow[t]{4}{*}{56.5} \\
\hline & \$95T003890 & Lower $1 / 2$ & 3,570 & 2,810 & 3,190 & & \\
\hline \multirow[t]{2}{*}{ 95-AUG-043 } & S95T003895 & Upper $1 / 2$ & 12,000 & 11,500 & 11,800 & & \\
\hline & \$95T003900 & Lower $1 / 2$ & 11,000 & 12,700 & 11,800 & & \\
\hline \multicolumn{8}{|c|}{ Table A-36. Tank 241-SX-108 Analytical Results: Vanadium (ICP). } \\
\hline Segrient & $\begin{array}{l}\text { Sample } \\
\text { Number }\end{array}$ & Sub-Sample & Resilit & oup. & Mean & Overall & $\begin{array}{l}\text { RSD } \\
\text { (Mean) }\end{array}$ \\
\hline \multicolumn{3}{|c|}{ Sollds acid digest } & $18 / 8$ & $4 \mathrm{~g} / \mathrm{g}$ & .1819 & $\mu \mathrm{g} / \mathrm{g}$ & $\%$ \\
\hline \multirow[t]{2}{*}{ 95-AUG-042 } & S95T002482 & Upper $1 / 2$ & $<50.55$ & $<52.10$ & $<51.33$ & \multirow[t]{4}{*}{34} & \multirow[t]{4}{*}{19.0} \\
\hline & S95T002501 & Lower $1 / 2$ & $<25.49$ & $<26.175$ & $<25.83$ & & \\
\hline \multirow[t]{2}{*}{ 95-AUG-043 } & S95T002573 & Upper $1 / 2$ & 22.79 & 22.36 & 22.58 & & \\
\hline & S95T002579 & Lower $1 / 2$ & 36.24 & 36.37 & 36.31 & & \\
\hline \multicolumn{3}{|c|}{ Sollids: H, 0 otig/act } & $\mu g / s$ & $1.1 \% 9 / 9$ & $\mu \mathrm{g} g$ & $\mu \mathrm{g} / \mathrm{g}$ & 96 \\
\hline \multirow[t]{2}{*}{ 95-AUG-042 } & S95T003882 & Upper $1 / 2$ & $<32.20$ & $<37.20$ & $<34.7$ & \multirow[t]{4}{*}{$<27.0$} & \multirow[t]{4}{*}{$\mathrm{N} / \mathrm{A}$} \\
\hline & S95T003887 & Lower $1 / 2$ & $<37.40$ & $<30.1$ & $<33.8$ & & \\
\hline \multirow[t]{2}{*}{ 95-AUG-043 } & S95T003892 & Upper $1 / 2$ & $<18.20$ & $<18.3$ & $<18.3$ & & \\
\hline & \$95T003897 & Lower $1 / 2$ & $<21.70$ & $<20.8$ & $<21.3$ & & \\
\hline
\end{tabular}




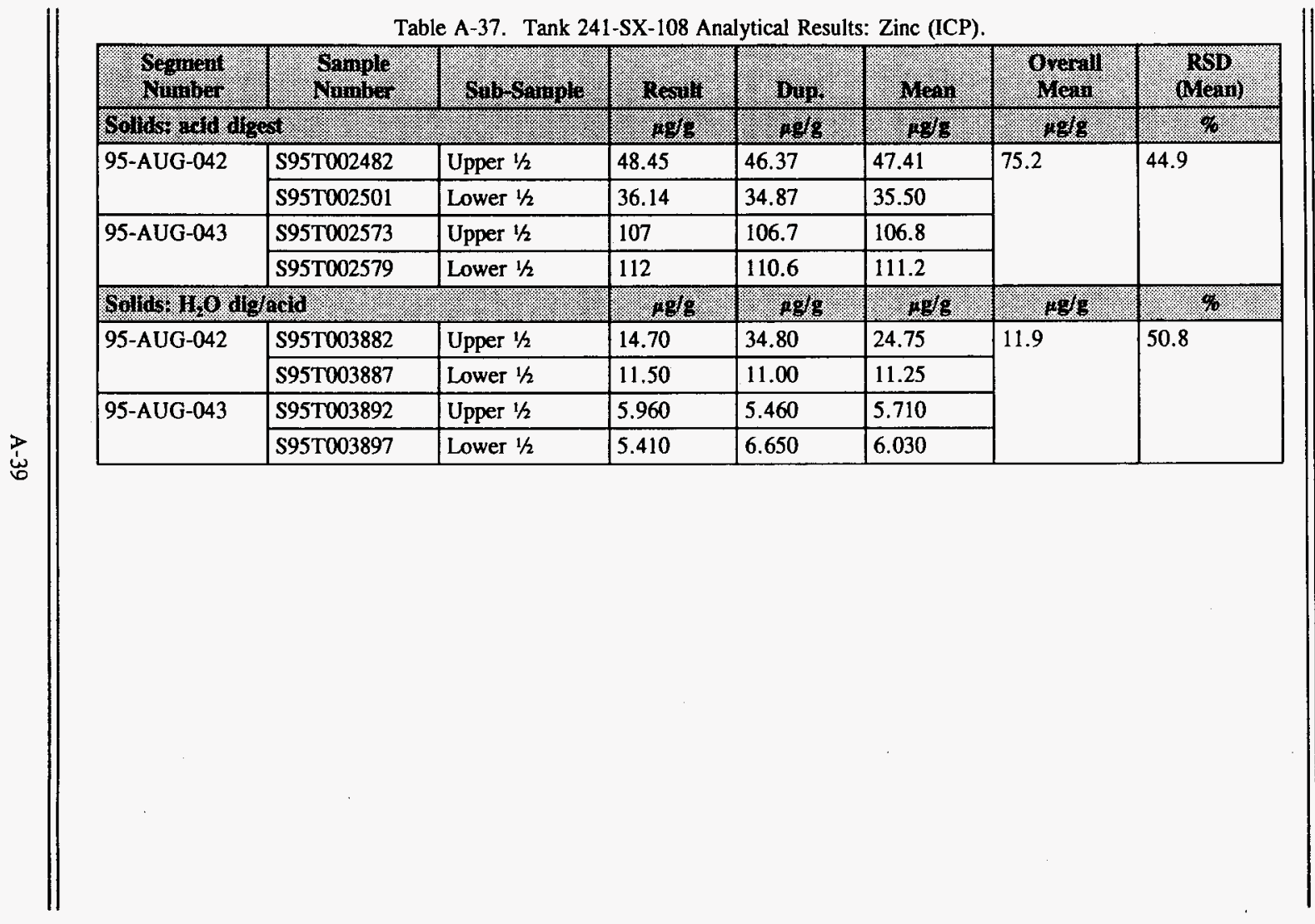




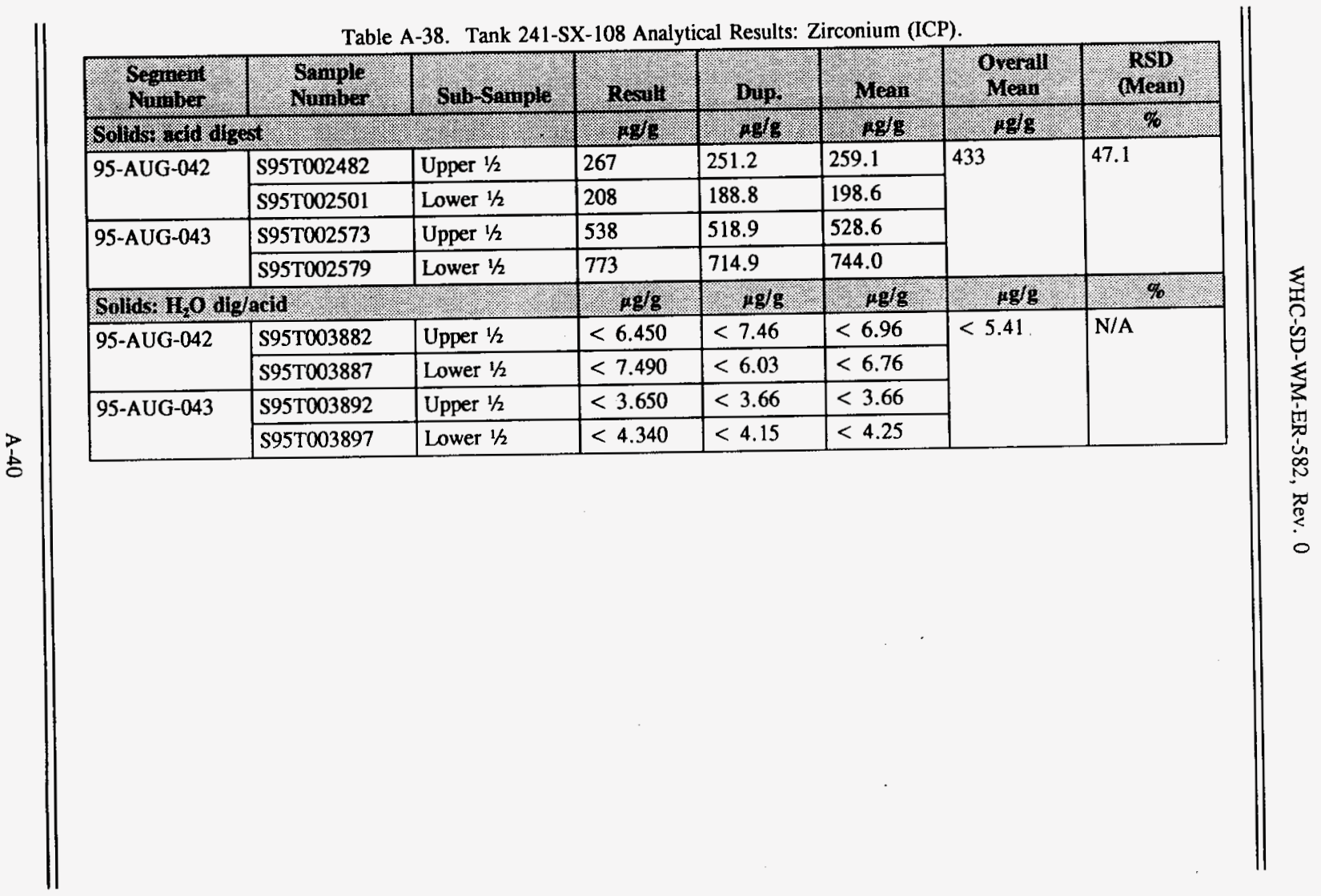


Table A-39. Tank 241-SX-108 Analytical Results: Bromide (IC).

\begin{tabular}{|c|c|c|c|c|c|c|c|}
\hline 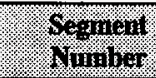 & (Sample & Spl & $(n-311)$ & 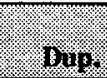 & Mean & Orenill & $\begin{array}{l}\text { RSO } \\
\text { (Mean) }\end{array}$ \\
\hline \multicolumn{3}{|c|}{ 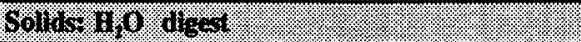 } & 1498 & ag/s & 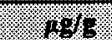 & 1498 & $\%$ \\
\hline \multirow[t]{2}{*}{ 95-AUG-042 } & S95T003881 & Upper $1 / 2$ & $<1,620$ & $<1,870$ & $<1,750$ & \multirow[t]{4}{*}{$<1,510$} & \multirow[t]{4}{*}{ N/A } \\
\hline & S95T003886 & Lower $1 / 2$ & $<1,880$ & $<1,520$ & $<1,700$ & & \\
\hline \multirow[t]{2}{*}{ 95-AUG-043 } & S95T003891 & Upper $1 / 2$ & $<1,200$ & $<1,210$ & $<1,200$ & & \\
\hline & S95T003896 & Lower $1 / 2$ & $<1,430$ & $<1,370$ & $<1,400$ & & \\
\hline
\end{tabular}

Table A-40. Tank 241-SX-108 Analytical Results: Chloride (IC).

\begin{tabular}{|c|c|c|c|c|c|c|c|}
\hline ovinim & $\begin{array}{l}\text { Samplo } \\
\text { Nrmber }\end{array}$ & Sub Sainple & Resull & Bup & Mean & Werail & $\begin{array}{l}\text { RSD } \\
\text { (Mean) }\end{array}$ \\
\hline \multicolumn{3}{|c|}{ Solids ing digest } & $\mathrm{HW}_{\mathrm{c}}$ & $\mu g / g$ & $\alpha g / g$ & $\mu g / g$ & $\%$ \\
\hline \multirow[t]{2}{*}{ 95-AUG-042 } & S95T003881 & Upper $1 / 2$ & 1,320 & 1,850 & 1,580 & \multirow[t]{4}{*}{2,160} & \multirow[t]{4}{*}{23.9} \\
\hline & S95T003886 & Lower $1 / 2$ & 1,840 & 1,570 & 1,700 & & \\
\hline \multirow[t]{2}{*}{ 95-AUG-043 } & S95T003891 & Upper $1 / 2$ & 2,620 & 2,640 & 2,630 & & \\
\hline & S95T003896 & Lower $1 / 2$ & 2,740 & 2,720 & 2,730 & & \\
\hline
\end{tabular}




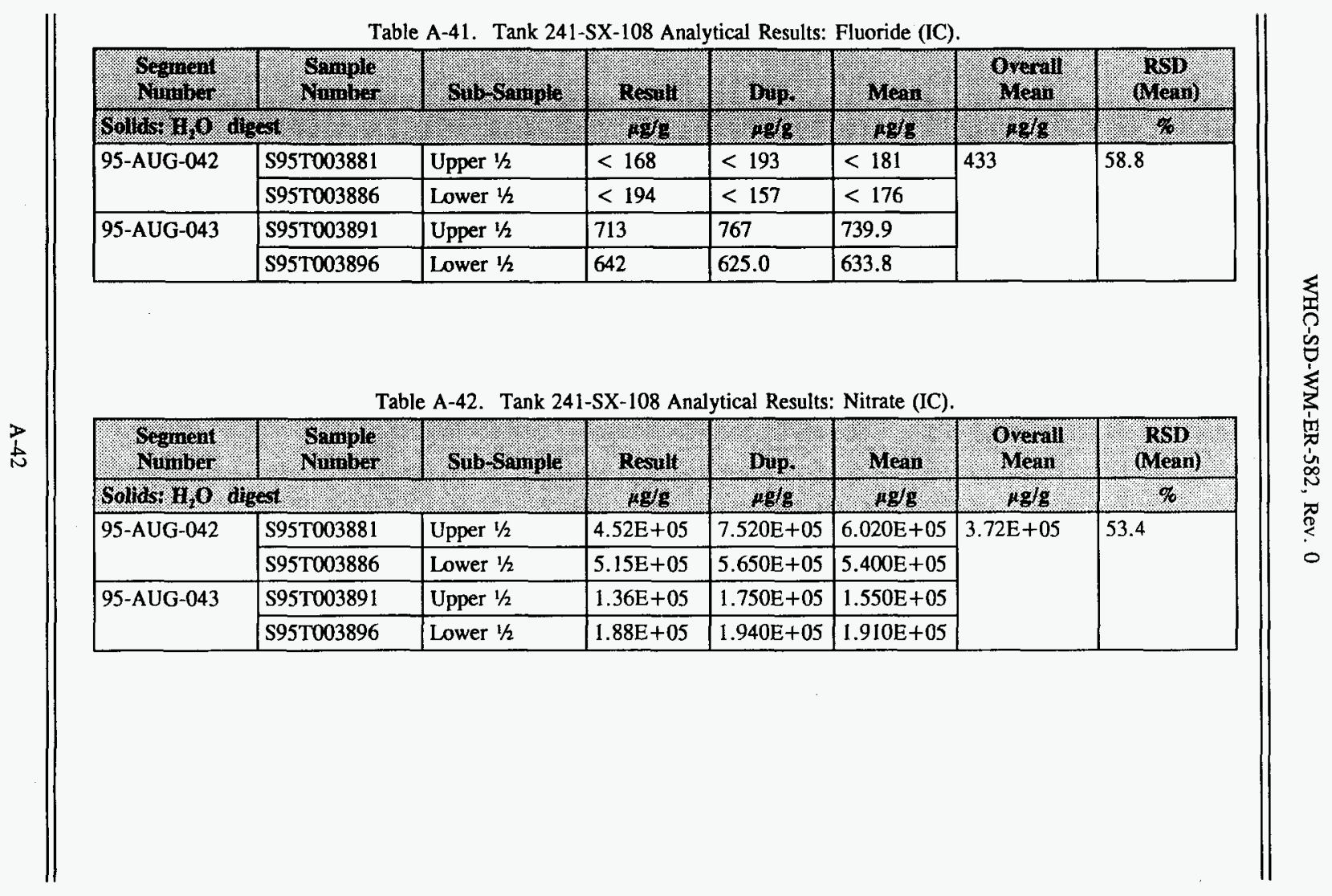


Table A-43. Tank 241-SX-108 Analytical Results: Nitrite (IC).

\begin{tabular}{|c|c|c|c|c|c|c|c|}
\hline$\psi_{0}$ & Gamp & 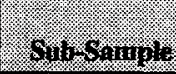 & (1) & $f_{40}$ & Yren & Men & mons \\
\hline \multicolumn{3}{|c|}{ 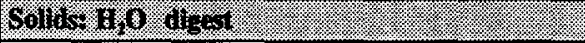 } & (2. & (1) & 69 & 189 & $\%$ \\
\hline \multirow[t]{2}{*}{ 95-AUG-042 } & S95T003881 & Upper $1 / 2$ & 14,500 & 21,900 & 18,200 & \multirow[t]{4}{*}{15,700} & \multirow[t]{4}{*}{30.0} \\
\hline & S95T003886 & Lower $1 / 2$ & 23,600 & 21,400 & 22,500 & & \\
\hline \multirow[t]{2}{*}{ 95-AUG-043 } & S95T003891 & Upper $1 / 2$ & 13,000 & 13,600 & 13,300 & & \\
\hline & S95T003896 & Lower $1 / 2$ & 8,790 & 8,490 & 8,640 & & \\
\hline
\end{tabular}

Table A-44. Tank 241-SX-108 Analytical Results: Oxalate (IC).

\begin{tabular}{|c|c|c|c|c|c|c|c|}
\hline $\begin{array}{l}\text { Soginert } \\
\text { Nhuner }\end{array}$ & $\begin{array}{l}\text { Sample } \\
\text { Mumber }\end{array}$ & . Sub Sample & resill & 10. & Nean & Overall & $\begin{array}{l}\text { RSDB } \\
\text { Meani) }\end{array}$ \\
\hline \multicolumn{3}{|c|}{ 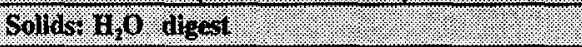 } & $.7 \mathrm{dg}$ & mg/g. & og/g & $196 / 9$ & $\%$ \\
\hline \multirow[t]{2}{*}{ 95-AUG-042 } & S95T003881 & Upper $1 / 2$ & $<1,350$ & $<1,560$ & $<1,460$ & \multirow[t]{4}{*}{3,130} & \multirow[t]{4}{*}{42.0} \\
\hline & S95T003886 & Lower $1 / 2$ & 4,930 & $<1,260$ & 3,095 & & \\
\hline \multirow[t]{2}{*}{ 95-AUG-043 } & \begin{tabular}{|l|} 
S95T003891 \\
\end{tabular} & Upper $1 / 2$ & $<1,000$ & 1,210 & 1,110 & & \\
\hline & S95T003896 & Lower $1 / 2$ & 6,510 & 7,180 & 6,850 & & \\
\hline
\end{tabular}


Table A-45. Tank 241-SX-108 Analytical Results: Phosphate (IC).

\begin{tabular}{|c|c|c|c|c|c|c|c|}
\hline Seanert & Shmpe & Sulo Siniple & incyil & Bin & Mran & Brerall & (1) Rean) \\
\hline \multicolumn{3}{|c|}{ 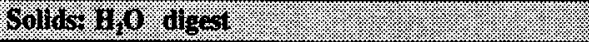 } & 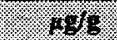 & agros & $198 \%$ & 1989 & 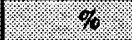 \\
\hline \multirow[t]{2}{*}{ 95-AUG-042 } & S95T003881 & Upper $1 / 2$ & $<1,540$ & $<1,780$ & $<1,660$ & \multirow[t]{4}{*}{$<1,440$} & \multirow[t]{4}{*}{ N/A } \\
\hline & S95T003886 & Lower $1 / 2$ & $<1,790$ & $<1,440$ & $<1,620$ & & \\
\hline \multirow[t]{2}{*}{ 95-AUG-043 } & S95T003891 & Upper $1 / 2$ & $<1,140$ & $<1,150$ & $<1,150$ & & \\
\hline & S95T003896 & Lower $1 / 2$ & $<1,360$ & $<1,300$ & $<1,330$ & & \\
\hline
\end{tabular}

Table A-46. Tank 241-SX-108 Analytical Results: Sulfate (IC).

\begin{tabular}{|c|c|c|c|c|c|c|c|}
\hline Sesment & Whinple & Sabsanple & Resull & bup. & Vear & $\begin{array}{l}\text { Syeral } \\
\text { Mean }\end{array}$ & $\begin{array}{l}\text { RSD } \\
\text { (Mean) }\end{array}$ \\
\hline \multicolumn{3}{|c|}{ Solldsr Higo digest } & 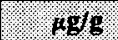 & $\% \mathrm{~g} / \mathrm{g}$ & 498 & $\mu \mathrm{g} / \mathrm{g}$ & $\%$ \\
\hline \multirow[t]{2}{*}{ 95-AUG-042 } & \$95T003881 & Upper $1 / 2$ & 8,960 & 11,700 & 10,300 & \multirow[t]{4}{*}{6,890} & \multirow[t]{4}{*}{34.0} \\
\hline & S95T003886 & Lower $1 / 2$ & 9,100 & 7,190 & 8,150 & & \\
\hline \multirow[t]{2}{*}{ 95-AUG-043 } & S95T003891 & Upper $1 / 2$ & 4,130 & 4,180 & 4,160 & & \\
\hline & \$95T003896 & Lower $1 / 2$ & 4,970 & 4,910 & 4,940 & & \\
\hline
\end{tabular}


Table A-47. Tank 241-SX-108 Analytical Results: Total Alpha.

\begin{tabular}{|c|c|c|c|c|c|c|c|}
\hline Women & 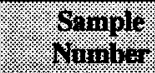 & (3) & $36-111$ & Buin & Herin & Grand & (ospan) \\
\hline \multicolumn{3}{|c|}{ 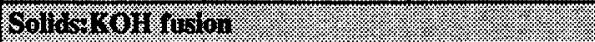 } & $\beta \%$ & 10 & 100 & $10 \%$ & \% \\
\hline \multirow[t]{2}{*}{ 95-AUG-042 } & S95T002481 & Upper $1 / 2$ & 1.960 & 1.950 & 1.955 & \multirow[t]{4}{*}{3.29} & \multirow[t]{4}{*}{45.6} \\
\hline & S95T002500 & Lower $1 / 2$ & 1.740 & 1.520 & $1.630^{\circ}$ & & \\
\hline \multirow[t]{2}{*}{ 95-AUG-043 } & S95T002572 & Upper $1 / 2$ & 4.070 & 4.320 & 4.195 & & \\
\hline & S95T002578 & Lower $1 / 2$ & 5.080 & 5.700 & $5.390^{\circ}$ & & \\
\hline
\end{tabular}

Table A-48. Tank 241-SX-108 Analytical Results: Total Beta.

\begin{tabular}{|c|c|c|c|c|c|c|c|}
\hline Yimen & Sample & Sub samplo & Revill & Wup. & Mean & Oreall & $\begin{array}{l}\text { ROD } \\
\text { (Menu) }\end{array}$ \\
\hline Solids finsion & & 1 & nCl18. & $101 / \mathrm{g}$ & $1401 / \mathrm{g}$ & $11 \mathrm{Clg}$ & $\%$ \\
\hline \multirow[t]{2}{*}{$95-A U G-042$} & S95T003885 & Upper $1 / 2$ & 3,590 & 3,260 & 3,420 & \multirow[t]{4}{*}{6,930} & \multirow[t]{4}{*}{52.1} \\
\hline & S95T003890 & Lower $1 / 2$ & 3,400 & 3,020 & $3,210^{c}$ & & \\
\hline \multirow[t]{2}{*}{ 95-AUG-043 } & S95T003895 & Upper $1 / 2$ & 10,500 & 10,900 & 10,700 & & \\
\hline & \$95T003900 & Lower $1 / 2$ & 10,400 & 10,300 & 10,400 & & \\
\hline
\end{tabular}


Table A-49. Tank 241-SX-108 Analytical Results: Cerium/Praseodymium-144 (GEA).

\begin{tabular}{|c|c|c|c|c|c|c|c|}
\hline 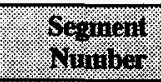 & 6ring & 6) & irsili & bup & Wong & $\begin{array}{l}\text { Wrall } \\
\text { oroni }\end{array}$ & $\begin{array}{l}\text { RSB } \\
\text { (M(an) }\end{array}$ \\
\hline \multicolumn{3}{|c|}{ 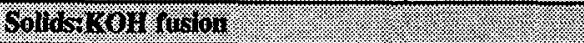 } & $n \%$ & $2 \%$ & 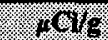 & (1) & $\%$ \\
\hline \multirow[t]{2}{*}{ 95-AUG-042 } & S95T002481 & Upper $1 / 2$ & $<5.443$ & $<5.03$ & $<5.24$ & \multirow[t]{4}{*}{$<18.6$} & \multirow[t]{4}{*}{ N/A } \\
\hline & S95T002500 & Lower $1 / 2$ & $<5.583$ & $<6.07$ & $<5.83$ & & \\
\hline \multirow[t]{2}{*}{ 95-AUG-043 } & S95T002572 & Upper $1 / 2$ & $<31.00$ & $<29.5$ & $<30.3$ & & \\
\hline & S95T002578 & Lower $1 / 2$ & $<33.14$ & $<32.6$ & $<32.9$ & & \\
\hline
\end{tabular}

Table A-50. Tank 241-SX-108 Analytical Results: Cobalt-60 (GEA).

\begin{tabular}{|c|c|c|c|c|c|c|c|}
\hline Segment & Wample & Silos Samples & Resiul & nino & Mean & Mreral & RSD \\
\hline \multicolumn{3}{|c|}{ Soldstabl Wuspor } & $10 \mathrm{Crg}$ & AC $y_{\mathrm{B}}$ & nctg. & $1 \mathrm{Clg}$ & $\%$ \\
\hline \multirow[t]{2}{*}{ 95-AUG-042 } & S95T002481 & Upper $1 / 2$ & $<.211$ & $<.146$ & $<.179$ & \multirow[t]{4}{*}{$<0.920$} & \multirow[t]{4}{*}{ N/A } \\
\hline & \$95T002500 & Lower $1 / 2$ & $<.194$ & $<.185$ & $<.190$ & & \\
\hline \multirow[t]{2}{*}{ 95-AUG-043 } & S95T002572 & Upper $1 / 2$ & $<1.477$ & $<1.87$ & $<1.67$ & & \\
\hline & S95T002578 & Lower $1 / 2$ & $<1.747$ & $<1.53$ & $<1.64$ & & \\
\hline
\end{tabular}


Table A-51. Tank 241-SX-108 Analytical Results: Cesium-134 (GEA).

\begin{tabular}{|c|c|c|c|c|c|c|c|}
\hline Whament & & $9116,5=1136$ & (rosinu) & Wyin & 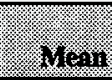 & ONoll & 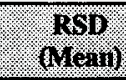 \\
\hline \multicolumn{2}{|c|}{ Collos } & W. & 10 & (W) & 16 & $\mathrm{~g}_{\mathrm{g}}$ & \% \\
\hline \multirow[t]{2}{*}{ 95-AUG-042 } & S95T002481 & Upper $1 / 2$ & $<.317$ & $<.308$ & $<.313$ & \multirow[t]{4}{*}{$<1.15$} & \multirow[t]{4}{*}{ N/A } \\
\hline & S95T002500 & Lower $1 / 2$ & $<.347$ & $<.367$ & $<.357$ & & \\
\hline \multirow[t]{2}{*}{ 95-AUG-043 } & S95T002572 & Upper $1 / 2$ & $<1.891$ & $<2.00$ & $<1.95$ & & \\
\hline & S95T002578 & Lower $1 / 2$ & $<2.086$ & $<1.87$ & $<1.98$ & & \\
\hline
\end{tabular}

Table A-52. Tank 241-SX-108 Analytical Results: Cesium-137 (GEA).

\begin{tabular}{|c|c|c|c|c|c|c|c|}
\hline $4 \%$ & $\begin{array}{l}\text { somple } \\
\text { Aminif }\end{array}$ & ano sample & thoul & Wip & Nean & Overall & (Mean) \\
\hline \multicolumn{3}{|c|}{ Solldsak of rosion } & $101 \%$ & $1 \% 1 / \mathrm{s}$ & (1) 19 & ncigg & $\%$ \\
\hline \multirow[t]{2}{*}{ 95-AUG-042 } & S95T002481 & Upper $1 / 2$ & 152 & 139.0 & 145.8 & \multirow[t]{4}{*}{195} & \multirow[t]{4}{*}{11.2} \\
\hline & S95T002500 & Lower $1 / 2$ & 212 & 261.0 & $236.3^{e}$ & & \\
\hline \multirow[t]{2}{*}{ 95-AUG-043 } & S95T002572 & Upper $1 / 2$ & 173 & 170.0 & 171.7 & & \\
\hline & S95T002578 & Lower $1 / 2$ & 221 & 231.0 & 226.2 & & \\
\hline
\end{tabular}


Table A-53. Tank 241-SX-108 Analytical Results: Europium-154 (GEA).

\begin{tabular}{|c|c|c|c|c|c|c|c|}
\hline WHineril & Soming & a & iresil & 4. & Hean & $6 \%$ & hovin \\
\hline \multicolumn{3}{|c|}{ 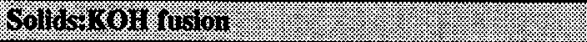 } & $10 \%$ & 11 & 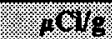 & $106 / \mathrm{s}$ & 4. \\
\hline \multirow[t]{2}{*}{ 95-AUG-042 } & S95T002481 & Upper $1 / 2$ & $<81.4$ & $<78.9$ & $<80.2$ & \multirow[t]{4}{*}{$<43.6$} & \multirow[t]{4}{*}{ N/A } \\
\hline & S95T002500 & Lower $1 / 2$ & $<86.0$ & $<84.5$ & $<85.3$ & & \\
\hline \multirow[t]{2}{*}{ 95-AUG-043 } & S95T002572 & Upper $1 / 2$ & $<4.283$ & $<.585$ & $<2.43$ & & \\
\hline & S95T002578 & Lower $1 / 2$ & $<6.456$ & $<6.35$ & $<6.40$ & & \\
\hline
\end{tabular}

Table A-54. Tank 241-SX-108 Analytical Results: Europium-155 (GEA).

\begin{tabular}{|c|c|c|c|c|c|c|c|}
\hline Sogrient & Gamplos & Sulb sample & Result & Bup. & Mear & oreral & $\begin{array}{l}\text { RSD } \\
\text { (Mean) }\end{array}$ \\
\hline \multicolumn{2}{|c|}{ Solldsikor rusion. } & 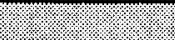 & $\mathrm{nO}_{\mathrm{s}}$ & $1 \mathrm{~N}_{\mathrm{g}}$ & $101 / \mathrm{g}$ & $140 \mathrm{~g}$ & $\%$ \\
\hline \multirow[t]{2}{*}{ 95-AUG-042 } & S95T002481 & Upper $1 / 2$ & $<1.463$ & $<1.36$ & $<1.41$ & \multirow[t]{4}{*}{$<5.17$} & \multirow[t]{4}{*}{ N/A } \\
\hline & S95T002500 & Lower $1 / 2$ & $<1.412$ & $<1.54$ & $<1.48$ & & \\
\hline \multirow[t]{2}{*}{ 95-AUG-043 } & \$95T002572 & Upper $1 / 2$ & $<8.173$ & $<8.80$ & $<8.49$ & & \\
\hline & S95T002578 & Lower $1 / 2$ & $<9.293$ & $<9.26$ & $<9.28$ & & \\
\hline
\end{tabular}


Table A-55. Tank 241-SX-108 Analytical Results: Niobium-94 (GEA).

\begin{tabular}{|c|c|c|c|c|c|c|c|}
\hline Seamentime & . Wampl & 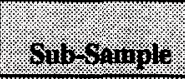 & Kesuly & bup & Mean & Oraral & MOD \\
\hline \multicolumn{3}{|c|}{ 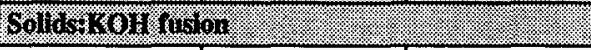 } & mo & $1 \%$ & (n) & - 4016 & $4.8 \%$ \\
\hline \multirow[t]{2}{*}{ 95-AUG-042 } & S95T002481 & Upper $1 / 2$ & $<0.206$ & $<0.174$ & $<0.190$ & \multirow[t]{4}{*}{$<0.915$} & \multirow[t]{4}{*}{ N/A } \\
\hline & S95T002500 & Lower $1 / 2$ & $<0.212$ & $<0.183$ & $<0.120$ & & \\
\hline \multirow[t]{2}{*}{ 95-AUG-043 } & S95T002572 & Upper $1 / 2$ & $<1.733$ & $<1.85$ & $<1.79$ & & \\
\hline & S95T002578 & Lower $1 / 2$ & $<1.817$ & $<1.31$ & $<1.56$ & & \\
\hline \multicolumn{8}{|c|}{ Table A-56. Tank 241-SX-108 Analytical Results: Radium-226 (GEA). } \\
\hline Gegment & . & Sub suinglo & Resill & 19up & Meari & $\begin{array}{l}\text { Overall } \\
\text { Mean }\end{array}$ & $\begin{array}{l}\text { RSD } \\
\text { Mean) } \\
\end{array}$ \\
\hline \multicolumn{3}{|c|}{ Solldskof rusion } & 1.919 & $1 / w_{6}$ & $\mathrm{nOMg}$ & $\mathrm{nou}$ & 7\%. \\
\hline \multirow[t]{2}{*}{ 95-AUG-042 } & S95T002481 & Upper $1 / 2$ & $<9.613$ & $<8.97$ & $<9.29$ & \multirow[t]{4}{*}{$<30.6$} & \multirow[t]{4}{*}{$N / A$} \\
\hline & \$95T002500 & Lower $1 / 2$ & $<9.937$ & $<11.1$ & $<10.5$ & & \\
\hline \multirow[t]{2}{*}{ 95-AUG-043 } & S95T002572 & Upper $1 / 2$ & $<48.93$ & $<46.2$ & $<47.6$ & & \\
\hline & S95T002578 & Lower $1 / 2$ & $<56.09$ & $<54.0$ & $<55.0$ & & \\
\hline
\end{tabular}


Table A-57. Tank 241-SX-108 Analytical Results: Ruthenium/Rhodium-106 (GEA).

\begin{tabular}{|c|c|c|c|c|c|c|c|}
\hline 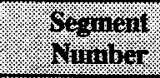 & Nample & 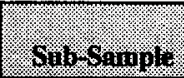 & ieriut & Dup & Wlon & $\begin{array}{l}\text { oretrill } \\
\mathrm{heni}\end{array}$ & $\begin{array}{l}\text { RAB } \\
\text { (Mean) }\end{array}$ \\
\hline \multicolumn{3}{|c|}{ Sollswnor ruston } & \% & $1 / 1 / 8$ & (1) & (4) & 8 \\
\hline \multirow[t]{2}{*}{ 95-AUG-042 } & S95T002481 & Upper $1 / 2$ & $<6.553$ & $<6.07$ & $<6.31$ & \multirow[t]{4}{*}{$<24.1$} & \multirow[t]{4}{*}{ N/A } \\
\hline & S95T002500 & Lower $1 / 2$ & $<7.034$ & $<7.94$ & $<7.49$ & & \\
\hline \multirow[t]{2}{*}{ 95-AUG-043 } & S95T002572 & Upper $1 / 2$ & $<39.89$ & $<39.9$ & $<39.9$ & & \\
\hline & S95T002578 & Lower $1 / 2$ & $<46.49$ & $<39.2$ & $<42.8$ & & \\
\hline
\end{tabular}

Table A-58. Tank 241-SX-108 Analytical Results: Strontium-89-90 (GEA).

\begin{tabular}{|c|c|c|c|c|c|c|c|}
\hline $\begin{array}{l}\text { S-ginen } \\
\text { Miniver }\end{array}$ & $\begin{array}{l}\text { Somplo } \\
\text { Nompros }\end{array}$ & Sub Sample & Resill & Bup & Meas & $\begin{array}{l}\text { Orerall } \\
\text { Mear }\end{array}$ & $\begin{array}{l}\text { RSD } \\
\text { (Mean) }\end{array}$ \\
\hline \multicolumn{3}{|c|}{ SollasthoH hision } & $20 \%$ & $=10 / \mathrm{s}$ & nowg & $\mathrm{ACl} / \mathrm{g}$ & $\%$ \\
\hline \multirow[t]{2}{*}{ 95-AUG-042 } & S95T002481 & Upper $1 / 2$ & 1,630 & 1,440 & 1,540 & \multirow[t]{4}{*}{3,070} & \multirow[t]{4}{*}{52.3} \\
\hline & S95T002500 & Lower $1 / 2$ & 1,350 & 1,430 & 1,390 & & \\
\hline \multirow[t]{2}{*}{ 95-AUG-043 } & S95T002572 & Upper $1 / 2$ & 4,130 & 4,510 & 4,320 & & \\
\hline & S95T002578 & Lower $1 / 2$ & 4,910 & 5,110 & 5,010 & & \\
\hline
\end{tabular}


Table A-59. Tank 241-SX-108 Analytical Results: TOC (Persulfate/Coulometry).

\begin{tabular}{|c|c|c|c|c|c|c|c|}
\hline $\begin{array}{l}\text { Segment: } \\
\text { Numimer }\end{array}$ & $\begin{array}{l}\text { Sample } \\
\text { Number }\end{array}$ & Sine Siniple & Resill & Dowe. & Vitan & $\begin{array}{c}\text { Overall } \\
\text { Menil }\end{array}$ & $\begin{array}{l}\text { RSD } \\
\text { (Mean) }\end{array}$ \\
\hline Sollins & in: & !ly & 180 & 86 & . $\mathrm{x} g / 3$ & 1048 & 1.7. \\
\hline \multirow[t]{2}{*}{ 95-AUG-042 } & S95T002480 & Upper $1 / 2$ & 142 & 154.0 & 148.0 & \multirow[t]{3}{*}{900} & \multirow[t]{3}{*}{86.8} \\
\hline & S95T002589 & Lower $1 / 2$ & 55.40 & 126.0 & 90.70 & & \\
\hline 95-AUG-043 & S95T000660 & Lower $1 / 2$ & 1,830 & 1,520 & 1,680 & & \\
\hline
\end{tabular}

Table A-60. Tank 241-SX-108 Analytical Results: Weight Percent Water.

\begin{tabular}{|c|c|c|c|c|c|c|c|}
\hline $\begin{array}{l}\text { Segrient } \\
\text { Number }\end{array}$ & $\begin{array}{l}\text { Sarmple } \\
\text { Number }\end{array}$ & Subsample & Resuin & Dup & Mean & $\begin{array}{l}\text { Overall } \\
\text { Mean }\end{array}$ & $\begin{array}{l}\text { RSI } \\
\text { (Mean) }\end{array}$ \\
\hline \multicolumn{2}{|c|}{ Thernogravinetic Aralysis. } & (T.:. & $41 \%$ & $x+\%$ & wt\%. & (. $.7 \%$ & $\%$ \\
\hline \multirow[t]{2}{*}{95 -AUG-042 } & S95T002480 & Upper $1 / 2$ & 2.86 & 3.48 & $3.17^{c}$ & \multirow[t]{4}{*}{2.03} & \multirow[t]{4}{*}{55.1} \\
\hline & S95T002489 & Lower $1 / 2$ & 2.70 & 3.56 & $3.13^{e}$ & & \\
\hline \multirow[t]{2}{*}{ 95-AUG-043 } & S95T002567 & Upper $1 / 2$ & 0.591 & 1.621 & $1.106^{e}$ & & \\
\hline & S95T002577 & Lower $1 / 2$ & 0.535 & 0.897 & $0.716^{\mathrm{e}}$ & & \\
\hline \multicolumn{2}{|c|}{ Gravlanetric Analysis } & 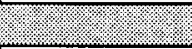 & . $11 \%$ & $41 \%$ & wi\%. & $\sqrt{10} 1 \%$ & $\%$ \\
\hline \multirow[t]{2}{*}{ 95-AUG-042 } & S95T002480 & Upper $1 / 2$ & 0.500 & 0.5000 & 0.5000 & \multirow[t]{2}{*}{0.475} & \multirow[t]{2}{*}{5.3} \\
\hline & S95T002489 & Lower $1 / 2$ & 0.500 & 0.4000 & $0.4500^{c}$ & & \\
\hline
\end{tabular}




\begin{tabular}{|c|c|c|c|c|c|}
\hline \multicolumn{6}{|c|}{ DISTRIBUTION SHEET } \\
\hline To & \multirow{2}{*}{\multicolumn{3}{|c|}{ From }} & \multicolumn{2}{|l|}{ Page 4 of 4} \\
\hline Distribution & & & & Date & $07 / 10 / 96$ \\
\hline \multicolumn{4}{|l|}{ Project Title/Work Order } & \multicolumn{2}{|c|}{ EDT No. EDT-616016 } \\
\hline \multicolumn{4}{|c|}{$\begin{array}{l}\text { Tank Characterization Report for Single-She11 Tank 241-SX-108, } \\
\text { WHC-SD-WM-ER-582, Rev. } 0\end{array}$} & \multicolumn{2}{|l|}{ ECN No. N/A } \\
\hline Name & MSIN & $\begin{array}{c}\text { Text } \\
\text { With All } \\
\text { Attach. }\end{array}$ & Text Only & $\begin{array}{l}\text { Attach./ } \\
\text { Appendix } \\
\text { Only }\end{array}$ & $\begin{array}{l}\text { EDT/ECN } \\
\text { Only }\end{array}$ \\
\hline
\end{tabular}

Westinghouse Hanford Company continued

W. C. Miller

C. T. Narquis

D. E. Place

D. A. Reynolds

L. M. Sasaki (2)

L. W. Shelton, Jr.

B. C. Simpson

G. L. Troyer

L. R. Webb

K. A. White

TEIC (Iank Farm Information Center)

Central Files

EDMC

ERC (Environmental Resource Center)

BSTI- (2) -

TCRC (10)

$\begin{array}{ll}\text { R1-30 } & X \\ \text { T6-16 } & X \\ \text { H5-27 } & X \\ \text { R2-11 } & X \\ \text { R2-12 } & X \\ H 5-49 & X \\ \text { R2-12 } & X \\ \text { T6-50 } & X \\ \text { T6-06 } & X \\ \text { S5-13 } & X \\ \text { R1-20 } & X \\ \text { A3-88 } & X \\ \text { H6-08 } & X \\ R 1-51 & X \\ \text { A3 }-36- & X \\ \text { R2-12 } & X\end{array}$




\section{DISTRIBUTION SHEET}

\begin{tabular}{|c|c|c|c|c|c|}
\hline$\overline{\text { To }}$ & \multirow{2}{*}{\multicolumn{3}{|c|}{$\begin{array}{c}\text { From } \\
\text { Data Assessment and } \\
\text { Interpretation }\end{array}$}} & \multicolumn{2}{|l|}{ Page 3 of 4} \\
\hline Distribution & & & & Date & $07 / 10 / 96$ \\
\hline \multicolumn{4}{|l|}{ Project Title/Work Order } & \multicolumn{2}{|c|}{ EDT No. EDT-616016 } \\
\hline \multicolumn{4}{|c|}{$\begin{array}{l}\text { Tank Characterization Report for Single-She11 Tank 241-SX-108, } \\
\text { WHC-SD-WM-ER-582, Rev. } 0\end{array}$} & \multicolumn{2}{|c|}{ ECN No. N/A } \\
\hline Name & MSIN & $\begin{array}{l}\text { Text } \\
\text { With All } \\
\text { Attach. }\end{array}$ & Text Only & $\begin{array}{l}\text { Attach./ } \\
\text { Appendix } \\
\text { Only }\end{array}$ & $\begin{array}{c}\text { EDT/ECN } \\
\text { Only }\end{array}$ \\
\hline
\end{tabular}

\section{ONSITE}

Department of Energy - Richland Operations
J. F. Thompson
W. S. Liou
N. W. Willis

$\begin{array}{ll}\text { S7-54 } & X \\ \text { S7-54 } & X \\ \text { S7-54 } & X\end{array}$
$x$
$x$
$x$

ICF-Kaiser Hanford Company
R. L. Newe 11
S3-09
$x$

Pacific Northwest Laboratory

N. G. Colton

J. R. Gormsen

S. A. Hartley

J. G. Hill

G. J. Lumetta

A. F. Noonan

West inghouse Hanford Company

H. Babad

D. A. Barnes

G. R. Bloom

R. J. Cash

W. L. Cowley

G. T. Dukel ow

G. L. Dunford

E. J. Eberlein

R. F. Eggers

D. B. Engelman

J. S. Garfield

J. D. Guberski

D. L. Herting

D. C. Hetzer

G. Jansen

G. D. Johnson

T. J. Kelley

N. W. Kirch

M. J. Kupfer

J. E. Meacham

$\begin{array}{lc}\text { K3-75 } & x \\ \text { K7-28 } & x \\ \text { K5-12 } & x \\ \text { K7-94 } & x \\ \text { P7-25 } & x \\ \text { K9-81 } & X\end{array}$

S7-14

R1-80

H5-61

S7-14

A3-37

S7-14

S7-81

R2-12

R2-12

R1-49

H5-49

R2-06

T6-09

S6-31

H6-33

S7- 15

S7-21

R2-11

H5-49

S7-15

x




\begin{tabular}{|c|c|c|c|c|c|}
\hline \multicolumn{6}{|c|}{ DISTRIBUTION SHEET } \\
\hline To & \multirow{2}{*}{\multicolumn{3}{|c|}{ From }} & \multicolumn{2}{|l|}{ Page 2 of 4} \\
\hline Distribution & & & & Date & $07 / 10 / 96$ \\
\hline \multicolumn{4}{|l|}{ Project Title/Work Order } & \multicolumn{2}{|c|}{ EDT No. $\quad$ EDT -616016} \\
\hline \multicolumn{4}{|c|}{$\begin{array}{l}\text { Tank Characterization Report for Single-She } 11 \text { Tank 241-SX-108, } \\
\text { WHC-SD-WM-ER-582, Rev. } 0\end{array}$} & \multicolumn{2}{|l|}{ ECN No. $\quad N / A$} \\
\hline Name & MSIN & $\begin{array}{c}\text { Text } \\
\text { With All } \\
\text { Attach. }\end{array}$ & Text Only & $\begin{array}{l}\text { Attach./ } \\
\text { Appendix } \\
\text { Only }\end{array}$ & $\begin{array}{l}\text { EDT/ECN } \\
\text { Only }\end{array}$ \\
\hline
\end{tabular}

\section{SAIC}

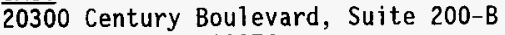

Germantown, MD 20874

H. Sutter

$x$

555 Quince 0rchard Rd., Suite 500

Gaithersburg, MD 20878

P. Szerszen

$X$

Los Alamos Laboratory

CST-14 MS-J586

P. 0. Box 1663

Los A1amos, NM 87545

S. F. Agnew (4)

$x$

Los Alamos Technical Associates

T. T. Tran

Bl-44

$x$

Ogden Environmental

101 East Wel1sian Way

Richland, WA 99352

R. J. Anema

$x$

CH2M Hi11

P. 0. BOX 91500

Bell levue, WA 98009-2050

M. McAfee

Tank Advisory Panel

102 Windham Road

Oak Ridge, TN 37830

D. 0. Campbe 11

$X$ 


\section{DISTRIBUTION SHEET}

\begin{tabular}{|c|c|c|c|c|c|}
\hline To & \multirow{2}{*}{\multicolumn{3}{|c|}{$\begin{array}{l}\text { From } \\
\text { Data Assessment and } \\
\text { Interpretation }\end{array}$}} & \multicolumn{2}{|l|}{ Page 1 of 4} \\
\hline Distribution & & & & \multicolumn{2}{|l|}{ Date } \\
\hline \multicolumn{4}{|l|}{ Project Title/Work Order } & \multicolumn{2}{|c|}{ EDT No. EDT-616016 } \\
\hline \multicolumn{4}{|c|}{$\begin{array}{l}\text { Tank Characterization Report for Single-She11 Tank 241-SX-108, } \\
\text { WHC-SD-WM-ER-582, Rev. } 0\end{array}$} & \multicolumn{2}{|l|}{ ECN No. $\quad$ N/A } \\
\hline Name & MSIN & $\begin{array}{l}\text { Text } \\
\text { With All } \\
\text { Attach. }\end{array}$ & Text Only & $\begin{array}{l}\text { Attach./ } \\
\text { Appendix } \\
\text { Only }\end{array}$ & $\begin{array}{l}\text { EDT/ECN } \\
\text { Only }\end{array}$ \\
\hline
\end{tabular}

\section{OFFSITE}

\section{Sandia National Laboratory}

P.0. Box 5800

MS-0744, Dept. 6404

Albuquerque, NM 87815

D. Powers

Nuclear Consulting Services Inc.

P. 0. Box 29151

Columbus, $\mathrm{OH}$ 43229-01051

J. L. Kovach

$X$

Chemical Reaction Sub-TAP

P.0. Box 271

Lindshorg, KS 67456

B. C. Hudson

$x$

Tank Characterization Panel

Senior Technical Consultant

Contech

7309 Indian School Road

A1buquerque, NM 87110

J. Arvisu

$X$

U. S. Department of Enerqy - Headquarters

office of Environmental Restoration and Waste Management EM-563 12800 Middlebrook Road

Germantown, MD 20874
J. A. Poppitti
$X$

Jacobs Enqineering Group

B5-36

$x$ 